\title{
4. The Red Glow of Partisan Photography
}

After the collapse of the Kingdom of Yugoslavia's army and the monarchy's surrender on 14 April 1941, the Communist Party of Yugoslavia fomented an uprising against the Axis forces and the quisling states in July. Professional photographers also joined them, many of whom quickly became the architects of Partisan photography. They often came from the ranks of small commercial photography businesses. Besides these there were, however, also pre-war amateurs, including those from hiking societies. Interestingly, for a time hiking groups played a large part in the spread and popularity of amateur photography.

During this period, the Partisan units did not have the conditions required to capture high-calibre shots, develop negatives, or make good-quality prints. They lacked film laboratories and equipment such as darkroom, processing chemicals, developer and fixer baths, enlarger and safelight. In periods when they were constantly on the move, changing base and living outdoors, it was extremely difficult to create an environment with the optimal temperatures required for all chemicals used in film processing. Photographers faced great challenges, and with only black-and-white film available to them, they could only record the world in tones of grey.

One problem was that they were unable to get hold of the polarising filters needed to block parts of the light spectrum, with the result, for example, that the most important symbol of the Partisan struggle - the red star - was reduced to an indistinct blur on the Partisan cap. Over time, the Partisans became accustomed to such complex conditions and they learnt how to make the most of their tools in the wartime situation, so that the five-pointed star eventually became much clearer to see. Despite the monochromy of expression available to them, Partisan photographs in fact exuded the red glow of the proletarian struggle for social change. Paradoxically, such early photographs left an indelible mark on the collective psyche, with the black-and-white five-pointed star carrying a powerful dual meaning: life in death and peace in war. This chapter presents an overview of photographic activities among the Partisans. In so doing, it draws attention to various other features of Partisan photography.

\section{The Early Days of Partisan Photography}

The first Partisan photographs emerged in 1941, when photography-related activities were still inadequately organised. In August of that year, Slavko Smolej, a member of Fotoklub Ljubljana, took pictures of the scenes following the sabotaging of an aqueduct in the Upper 
Carniola (Gorenjska) region of Slovenia by a company of Partisans from Jesenje. ${ }^{1}$ Commanders such as Mirko Bračić, Jule Sočan and Jože Kotnik photographed events in the Partisan units. ${ }^{2}$ Underground activists in Slovenian cities, such as Sočan in Ljubljana, ${ }^{3}$ distributed banned literature, poetry books and leaflets, and also photographed the buildings and places they lived in while under cover. Sočan soon joined Partisan ranks, taking two cameras with him that he later used to take important shots of the Tomšič Brigade. Photographs were also used to forge identity papers, which were extremely important to party members and resistance fighters when moving between cities and localities. Such movement was vital for coordinating and linking up all parts of the resistance effort, and for passing on messages.

Besides the cameras that photographers had already brought with them upon joining the Partisan movement, German Leicas also started landing in Partisan hands, along with other material seized in skirmishes with German troops, including weapons and supplies. There are many reports citing the importance of plundered photographic equipment and listing the precise number of seized cameras and rolls of film. One of the earliest such reports is that of the general staff of the First Šumadija Partisan Detachment, dated 14 October 1941, in which they itemise the plundered weapons, munitions, food and photographic equipment. ${ }^{4}$

After a successful uprising in Serbia in June 1941 and the creation (on 24 September) of the first liberated territory in occupied Europe - the Republic of Užice - the Partisans had a small quantity of photographic supplies available to them, and some photographs too. The painting studio responsible for preparations for the exhibition on the USSR (held in the small sports hall of the local chapter of the Sokol Society) chose to exhibit mainly prints, drawings, sketches and paintings, ${ }^{5}$ with just one small section featuring photographs. ${ }^{6}$

After the collapse of the Republic of Užice on 29 November 1941, Partisan resistance in Serbia was thwarted. The main body of Partisan troops retreated towards Sandžak, later moving towards Bosnia and Herzegovina. Serbia came under German occupation and Milan Nedić's quisling government, subordinated to the German Military Administration that governed all aspects of civic life. The Military Administration (Militärverwaltung) issued permits for only ten photo studios and photographers permitted to work for the German Wehrmacht. ${ }^{7}$ Aleksandar Aca Simić and Milan Roglić were both active as photographers in Serbia during the war. The latter took an iconic photograph of people riding a motorbike and sidecar during the Belgrade demonstrations against the Kingdom of Yugoslavia joining the Tripartite Pact. ${ }^{8}$ Besides these two photographers, most noteworthy photo-

\footnotetext{
1 Franc Fabec and Dejan Vončina, Slovenska odporniška fotografija 1941-1945, Ljubljana 2005, p. 44.

2 Tomaž Kladnik, Katarina Jurjavčić and Jože Dežman, Vojne fotografije 1941-1945, Partizanske jedinice, Ljubljana 2010 , p. 22.

3 Fabec/Vončina 2005 (see note 1), p. 45.

4 Zbornik dokumenata i podataka o narodno-oslobodilačkom ratu jugoslovenskih naroda, vol. 1/20, 1965, Borbe u Srbiji 1941-1944, Belgrade 1965.

5 Venceslav Glišić, Užička republika, Belgrade 1986, pp. 174-175.

6 Stojadin Kostić, 'Kulturna i umetnička aktivnost u partizanskom Užicu 1941', in: ibid., p. 328.

7 Novo vreme, 22 May 1941.

8 Roglić perfected his photographic techniques in Marseille. During the Second World War he was the official photographer for Milan Nedić's government. His photographs of 27 March 1941 were later printed in post-war history textbooks.
} 
graphic production in Serbia can be traced to the studios Miroč and Urošević, the Belgrade Photo Agency and the Photographic Department of State Propaganda. The photographer Risto Marjanović should also be mentioned in this context, best known for his photographs of the retreat of the Serbian army and Serbian people during the First World War, and later for his photographs of the liberation of Belgrade. His series of photographs depicting soldiers in peasant clothes without shoes is particularly haunting. ${ }^{9}$

In the Partisan movement in Serbia, the work of the amateur photographer Rade Jokić (from Valjevo in central Serbia) is especially interesting, and he ranks as one of the very first Partisan photographers. From research on this photographer recently published in Serbia, ${ }^{10}$ we learn that for his prints Jokić used Agfa's glossy bromide paper Brovira $(9 \times 12 \mathrm{~cm})$, which the Partisans most likely seized in combat or plundered from German units via some other means. Before the war, Jokić had bought a Leica IIIb with a Summar $50 \mathrm{~mm}$ lens. ${ }^{11}$ He took pictures of some of the first rebels in Serbia, such as Filip Kljajić-Fićo, the painter Bora Baruh and the sculptor Vladeta Piperski. Frequent motifs of his include Partisan military columns, life in a Partisan unit and peasants. One of Jokić's photographs, taken in August 1941 near the village of Kamenica outside Valjevo, shows Stjepan Filipović with comrades leading four German spies to their death by firing squad.12 (For more on Stjepan Filipović and his own execution, see chapter 7, 'Iconic Photographs'.) Looking at Jokić's photographs, one gets the strong sense that he was given little time to compose his shots, with many apparently taken on the run, while catching up with the column, ever at risk of being left behind:

The conditions for shooting film were exceedingly difficult. I had to quickly find a suitable corner to take pictures while the others were advancing, and afterwards we had to reach the column, keeping to the hill. It was difficult to capture on film and because of this, our comrades were not understanding enough. While I was loading the camera with a new roll of film, they would protest, demanding that the light be turned on or a candle be lit, so I had to go outside and work huddled under an overcoat beneath a canopy. They often couldn't grasp how important these documents would come to be after the war. They said: 'You're taking pictures while we're being killed.' I brought a certain amount of photo supplies with me when I left to join the Partisans, but I mostly used materials taken from captured Germans. After the fight at Stolice we seized a certain quantity of film, just as we did when we occupied Krupanj. We also seized one camera in Krupanj that I gave to Piperski to take pictures with. But he forgot it in our retreat. I managed to preserve the rolls of film by burying them in the wall of a barn at the home of the Belic family, in a village named Bogovađa. I shot a total of eleven rolls, each with thirty-six exposures, and after the war I gave them to my comrades. However, all these film rolls somehow got lost. I later received an order to search for them and managed to find only three or four in Zagreb. How they got there,

9 Milan Radanović, Oslobođenje. Beograd, oktobar 1944, Belgrade 2014 (Rosa Luxemburg Stiftung Southeast Europe), p. 81.

10 Branko Matić, Valjevski partizani 1941-1942: na fotografijama Rada Jokića, Valjevo 2015 (self-published).

11 Ibid., pp. 16-23.

12 Ibid., p. 101. 
I have no idea. Today, they are in the Military Museum in Belgrade. It turns out that one of these eleven rolls had already been used by the Germans, and I used the film for a second time without realising it. Once developed, you clearly saw the German and our military columns criss-crossing each other. I shot one film in colour but that also got lost. ${ }^{13}$

Stolice (near Krupanj) was a site in rural Serbia of key importance in the early days of the Partisan struggle. Besides Rade Jokić stationed in the Kolubara Company (Valjevo Detachment), another Partisan photographer taking pictures was Sreten Čitaković. He managed to get his hands on a Voigtländer camera after the struggle with German units in Stolice on 1 September 1941. He seized it along with several Agfa films, and he gave his Rodenstock camera as a present to his co-fighter, Miodrag Tatović. In the early days, they mostly took photographs by using seized German film, and only later did they succeed in getting hold of photographic materials through Partisan connections in the cities. ${ }^{14}$

Besides taking photos to document events, a small number of Sreten Čitakovićs photographs show his co-fighters' gentler side. He shot a portrait of Sofija Soja Stanišić, one of the first women to fight alongside her male counterparts in combat against German units, and Ivo 'Lola' Ribar and Aleksandar Ranković on horseback. Čitaković attempted to have

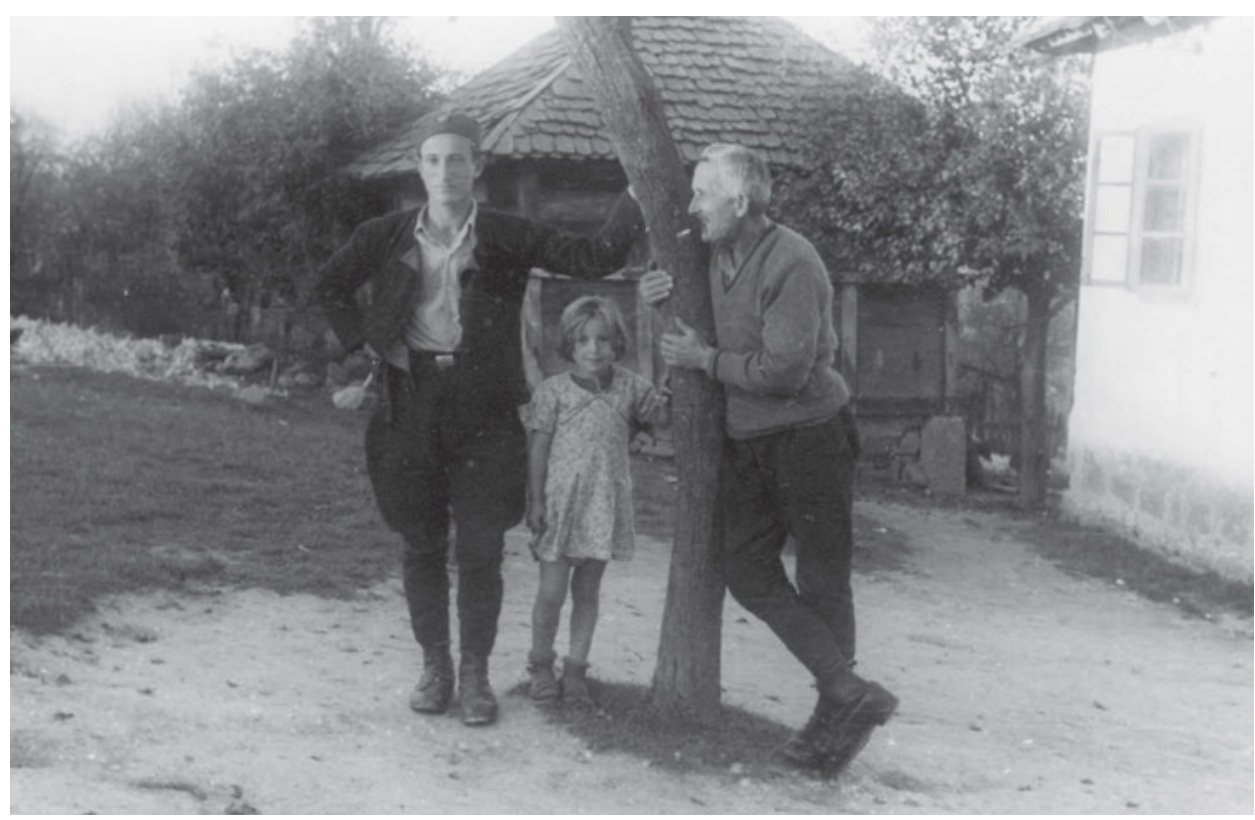

Dragoljub Dudić (right) and his son Miša Dudić, fighters in the Valjevo Detachment, Valjevska Kamenica, 1941. (The author Branko Matić claims that the photograph shows Miloš Milićević and Negosava Bojinović with Dragojlo Dudić.) Photo: Rade Jokić. Military Museum, Belgrade, 992.

13 Zdravko Ranković and Miroslav Jeremić, Kultura u prošlosti Valjevskog kraja, vol. 2: Slikarstvo, arhitektura, fotografija, skulptura: izbor tekstova emitovanih u emisijama Radio Valjeva, Valjevo 1979; see also Matić 2016 (see note 10), pp. 16-23.

14 Sreten Čitaković, 'Fotografije iz partizanskog života', in: Slikarstvo arhitektura fotografija skulptura. Izbor tekstova emitovanih u emisijama Radio Valjeva, Zoran Tripković (ed.), Valjevo 1979, p. 145. 
his photos duplicated and distributed by sending them across the territory of the Republic of Užice via a young girl, Milica Pavlović, from the Liberation Committee of the Communist Party of Yugoslavia (Valjevo chapter). ${ }^{15}$ But the rolls were irrevocably lost when German forces invaded on 29 November 1941. Čitaković also took photographs for fake identity papers:

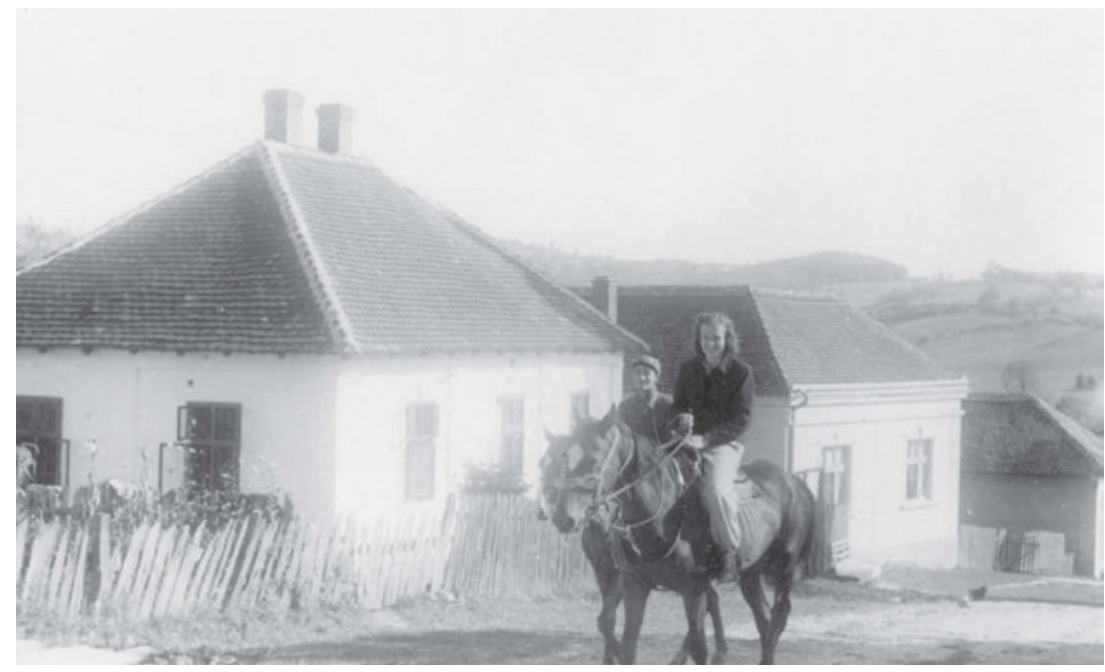

Miša Veličković and Sofija Stanišić, members of the Valjevo Detachment, Valjevska Kamenica, September 1941. Photo: Rade Jokić. Military Museum, Belgrade, 1004.

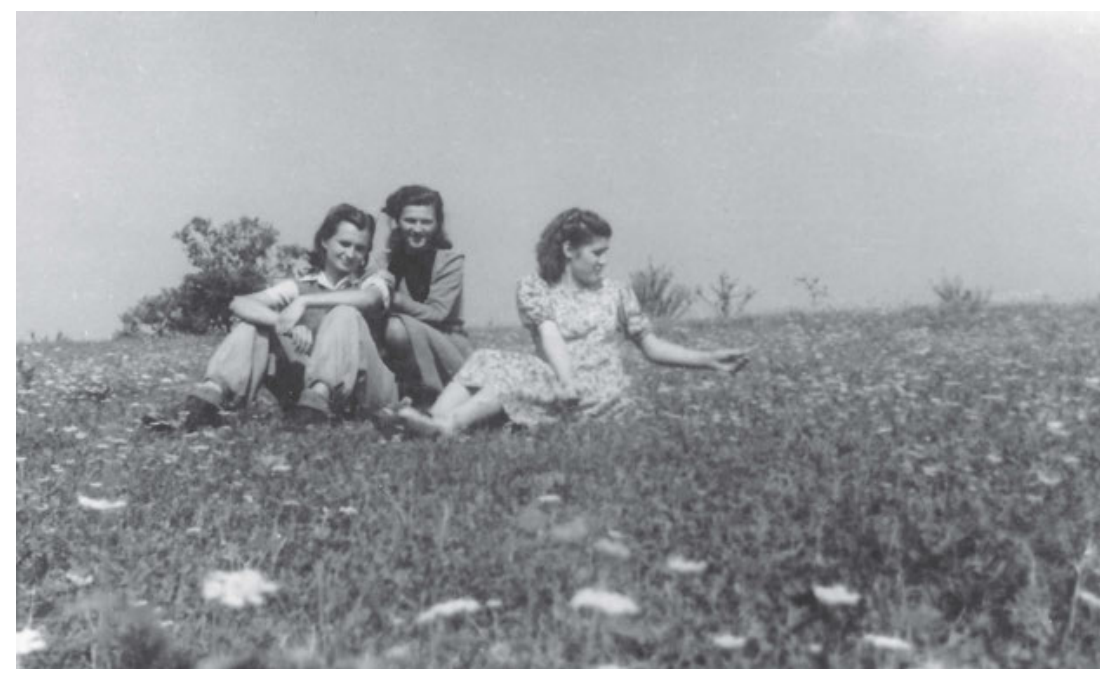

Members of the Valjevo Detachment (presumably Sofija Stanišić with two unknown friends), 1941. Photo: Rade Jokić. Military Museum, Belgrade, 1007. 
Our patrols were tasked with seizing unsigned, blank ID documents in local municipalities. When we arrived in the villages of Bukovac and Osečenica on 8 February or thereabouts, myself and one leader of the fighters went to the house of Milomir Uskoković, a photographer from Osečenica. I developed two film rolls at his house, dried them, and copied everything. I did it all myself, so Milomir didn't even see a single picture. He gave me everything I needed and was helpful throughout. We continued the journey to Brežđe, and I sent the photographs to Mirko Tomić. He delivered them to Bora Baruh who counterfeited a German stamp and turned these photographs into false identity papers. ${ }^{16}$

The first Partisan photographs in Croatia appeared in October 1941. Only two months after the first photographs emerged in Slovenia, an unknown photographer shot the first images of the Psunj Detachment. ${ }^{17}$ In December of the same year, Dr Vladimir Bakarić photographed the camp at Slunj. ${ }^{18}$ Bakarić was the General Staff of Croatia's political commissar (tasked with the staff's political education) and one of the founders of the ZAVNOH (State Anti-Fascist Council for the People's Liberation of Croatia). Later, as one of the leaders of the Partisan struggle, he had the opportunity to shoot photographs of historically important events in the People's Liberation Struggle, including images of the Partisans' Supreme Command during their stay on Vis in 1944.

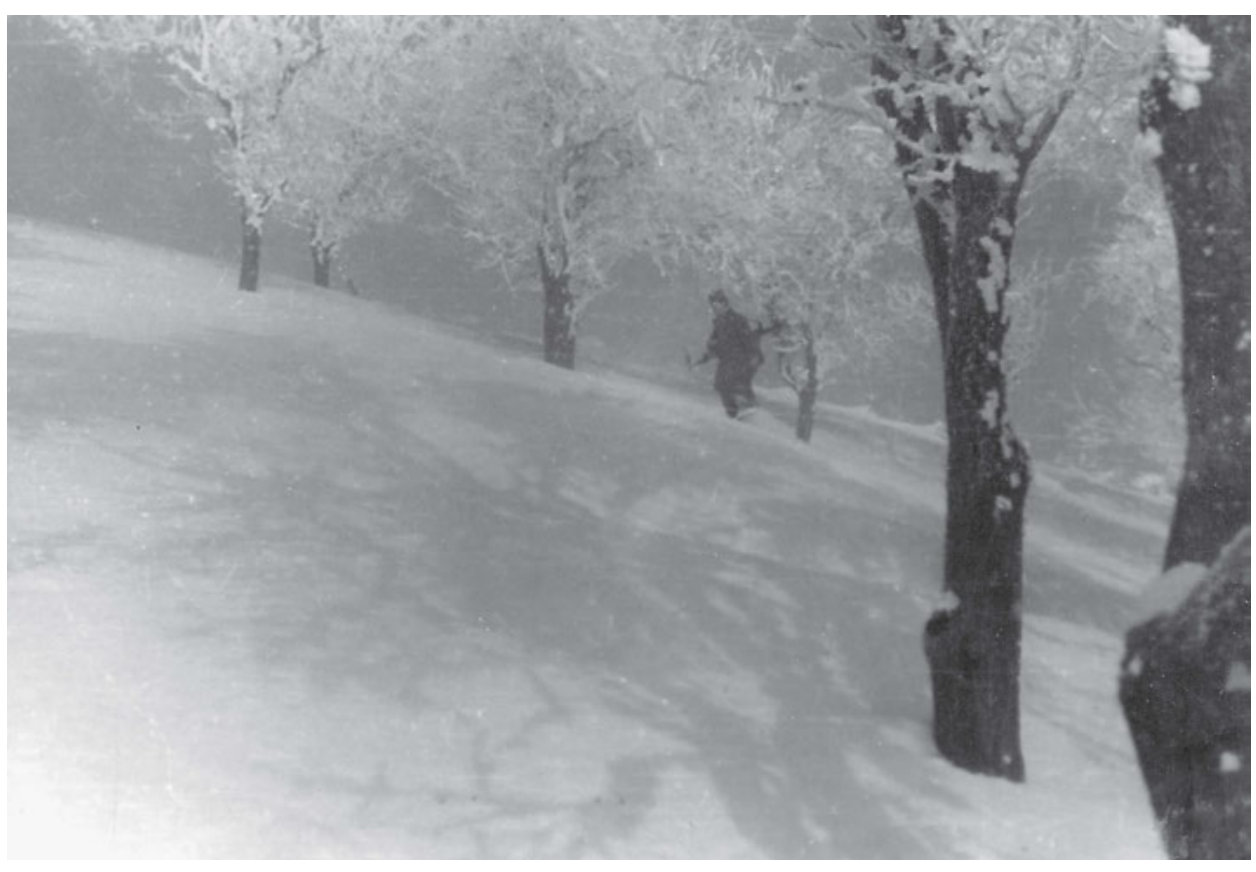

Guard patrolling in sub-zero temperatures, Leskovice, Serbia, February 1942.

Photo: Rade Jokić. Military Museum, Belgrade, 1161.

\footnotetext{
16 Ibid., p. 153.

17 Rhea Ivanuš, Fotografski albumi u zbirci fotografija, filmova i negativa Hrvatskoga povijesnog muzeja, Zagreb 2006, p. 23.

18 Branka Hlevnjak and Rhea Ivanuš, Hrvatska antiratna fotografija: Prvi svjetski, Drugi svjetski i Domovinski rat, Zagreb 2008, p. 111.
} 


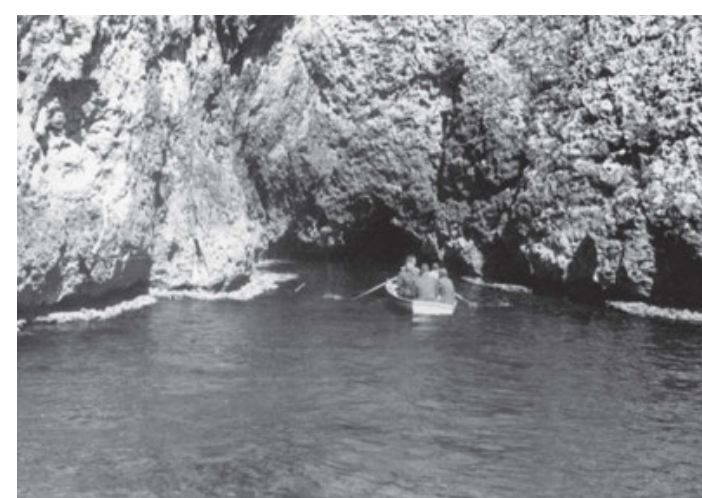

The entrance to the Blue Cave on the island of Biševo, 1944. Photo: Dr Vladimir Bakarić. Croatian History Museum, HPM/ MRNH-F-5986.

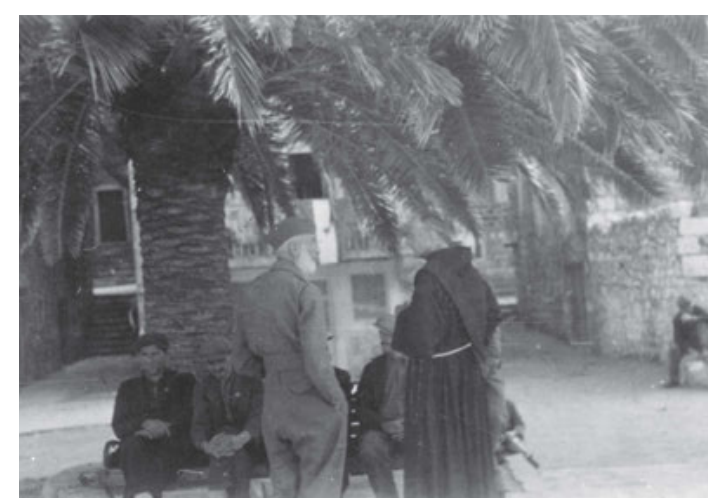

A group of delegates from the District Conference of the Unitary People's Liberation Front of Dalmatia, Hvar Island, 10 October 1944. Photo: Dr Vladimir Bakarić. Croatian History Museum, HPM/MRNH-F-5993.

\section{The First Partisan Exhibitions}

It is difficult to determine when the first Partisan photography exhibition was held, but it was likely the exhibition on 7 November 1942 in Bosanski Petrovac, in the second liberated territory - the Bihać Republic. Little data about the event itself has been preserved, but we do know that photographs shot by one of the first and particularly important Partisan photographers, Vili Šimunov-Barba, went on show there..$^{19}$ At that time, Bosanski Petrovac (liberated on 25 May 1942) became the administrative centre of the Bihać Republic. In this territory 'civil authorities' were organised by the People's Liberation Committees. These authorities were tasked with providing for all kinds of civilian needs. They also organised cultural and educational activities on liberated soil, such as in the Croatian coastal town of Selce in $1943 .{ }^{20}$ This is further proof that Partisan photography had a civic, artistic character during wartime. Though short-lived like the Republic of Užice before it, the Bihać Republic was the site of the first event in the Agricultural Youth Labour campaign. The action, in the valley of Sanička, was well documented in photographs, with the number of youth volunteers estimated to between 2,000 and 3,500. ${ }^{21}$ The Anti-Fascist Women's Front was also founded in Bosanski Petrovac on 6 December. ${ }^{22}$

The first Partisan photography exhibition was held on the day that the Supreme Commander, Josip Broz Tito, marshalled the First Proletarian Brigade. Its commander was the onetime Belgrade poet, Surrealist and volunteer in the Spanish Civil War, Koča Popović. Several days before the planned opening of the exhibition, on 20 October 1942, orders arrived from the chief of the Temporary Administrative Section of the Supreme Command of the

19 Pavle Jakšić, Nad uspomenama, vol. 1, Belgrade 1990, p. 277.

20 Vinko Antić, Vinodolska Selca u borbi, Selca 1975, p. 623.

21 Mile Trnjaković, 'Sjećanja na rad omladinske organizacije na području Bosanskog Petrovca do kraja 1942. godine', in: Bosanski Petrovac u NOB. Zbornik sjećanja, vol. 4, Vladimir Čerkez (ed.), Bosanski Petrovac 1974, p. 155.

22 For more on the Anti-Fascist Women's Front, see Andreja Dugandžić and Tijana Okić, The Lost Revolution: Women's Antifascist

Front between Myth and Forgetting, Sarajevo 2018. 


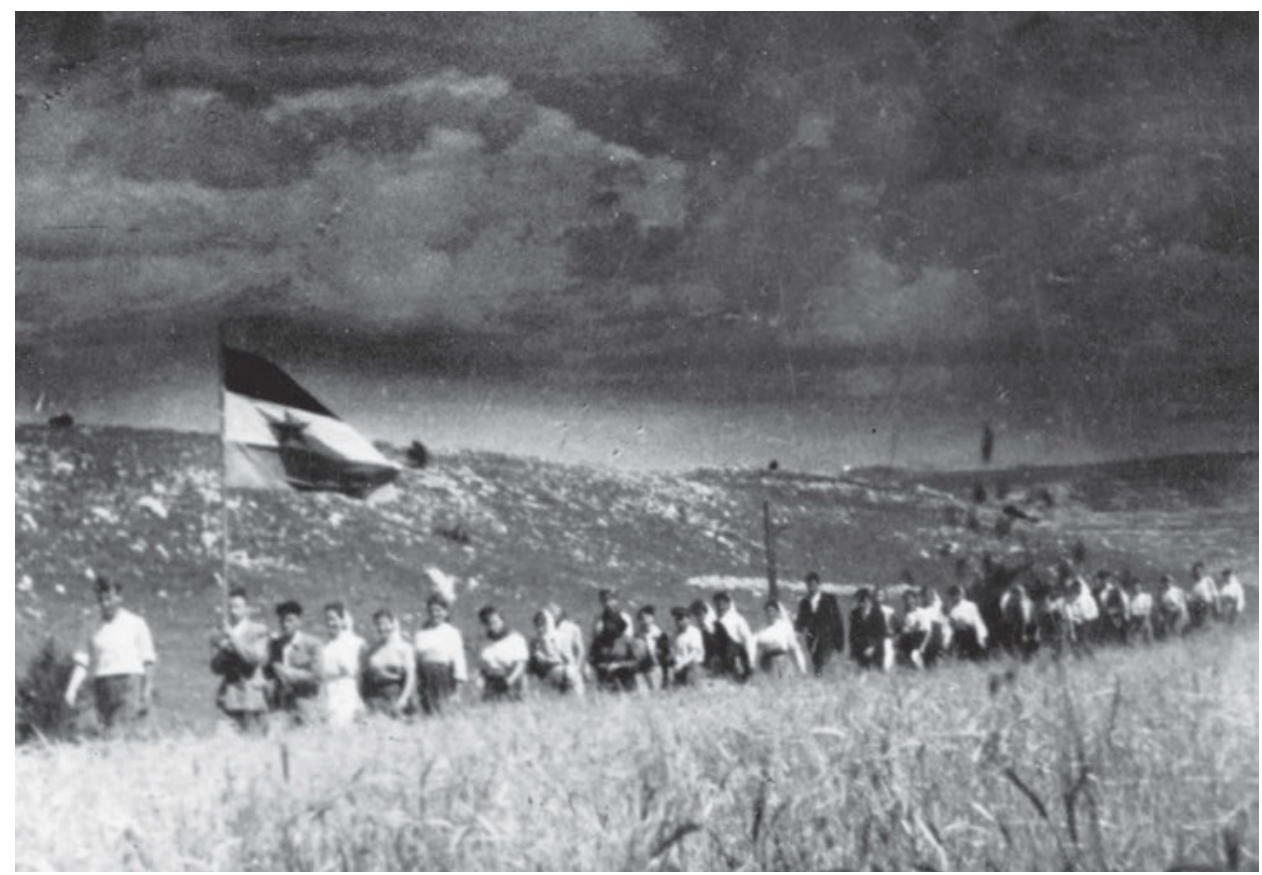

The Youth Battalion from the Bosnian town of Bosansko Grahovo, harvesting grain in the Sanička valley (Podgrmeč). Photographer unknown. History Museum of Bosnia and Herzegovina, FNOB 10737.

\begin{abstract}
People's Liberation Struggle of Yugoslavia, stating that the brigade staff and the Partisan detachments should submit examples of Partisan press and documentary material on the liberation struggle and on atrocities committed by the occupiers and their lackeys. All units were asked to submit examples of their own published news-sheets, brochures, pamphlets and other printed material, as well as enemy documents. They were also asked to supply Partisan photography, the texts to folk and Partisan songs, lists of victims, data on war crimes, lists and descriptions of campaigns, but also humorous and everyday accounts of life in the units. The order was signed by Moša Pijade. He was a pre-war communist, journalist and painter with the code name 'Čiča Janko'. It is interesting that photography was the second point listed in the order. This confirms that there was an awareness of its significance in the Partisan movement at the time. The order states that the comrades should supply:
\end{abstract}

A copy of every photograph taken of our struggle, including background details to the image, as well as seized enemy photographs (especially photographs of fascist atrocities). Also, photographs of some of our fallen heroes. On the back of each photograph, or on a list that may be attached to it, write what or who is depicted, when and where the image was taken and, if possible, to whom the picture belongs. Comrades are not to bemoan submitting the only print they have, because the photographs will be reproduced, and the originals can be later returned to 


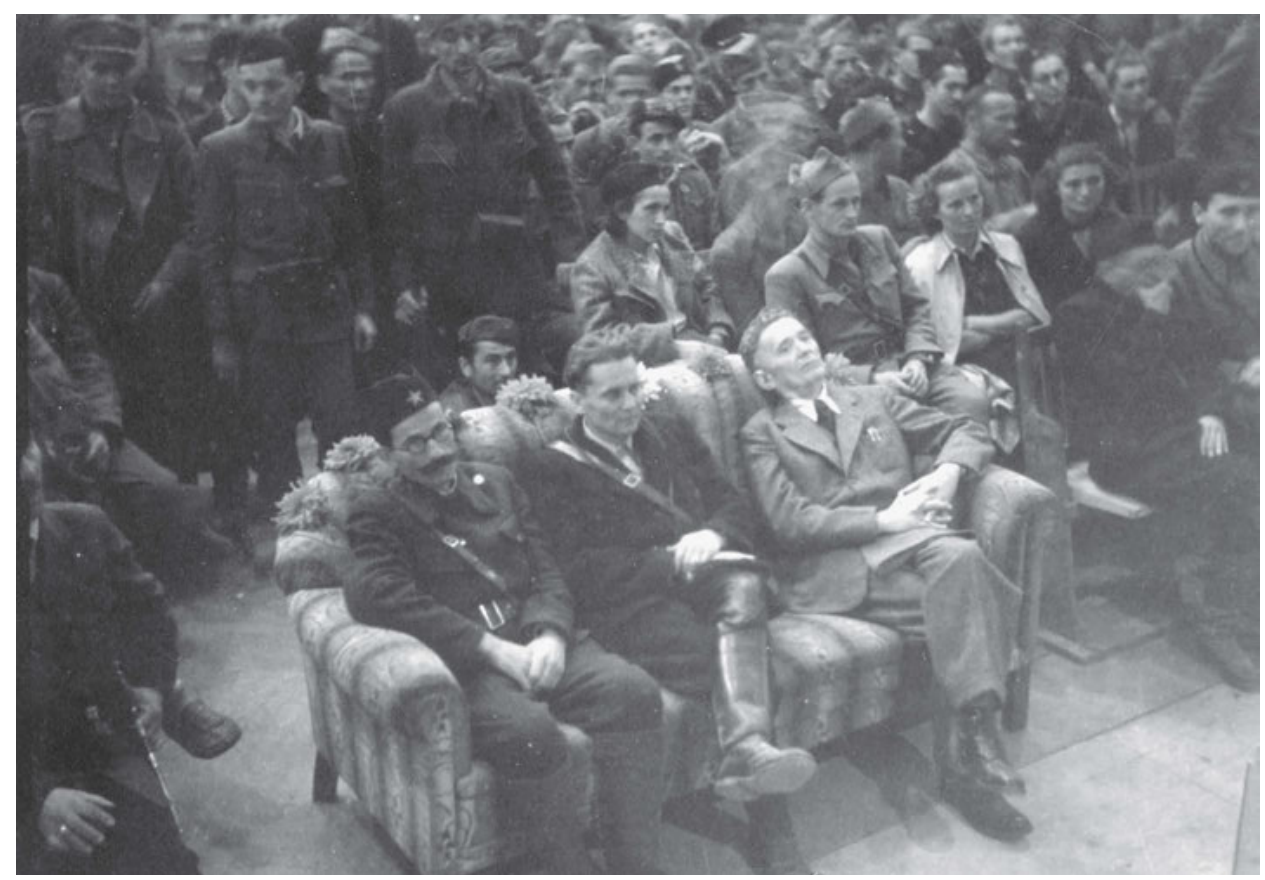

From left to right: Ivan Milutinović, Josip Broz Tito and Ivan Ribar watching a performance at the Theatre of People's Liberation, with Davorjanka Zdenka Paunović in the background, Bosanski Petrovac, 1942. Photo: Vili Šimunov-Barba. Military Museum, Belgrade, 4110.

them if they so wish. Concerning photographs that comrades think worth enlarging (if not all submitted photographic material in general), it is preferable if comrades attach the negative along with each print. ${ }^{23}$

One year after the exhibition in Bosanski Petrovac, on 27 November 1943, an exhibition (about which little is known) was held in the liberated town of Livno in honour of the Second Session of the AVNOJ (Anti-Fascist Council for the People's Liberation of Yugoslavia). ${ }^{24}$ The Slovenian poet Edvard Kocbek wrote about the exhibition in his diary. He was fascinated by photography and the atmosphere of the liberated city, and began to picture film scenes in his mind, even introducing camera movements. The political scientist Gal Kirn views Kocbek's notes as an outline for the first Partisan film script. ${ }^{25}$ The ensuing film is not so much a movie in the traditional sense, rather a series of photographs that we only envision in motion once we embrace the shortcomings of the human eye and mind.

The Republic of Užice and the Bihać Republic were the first territories where Partisan cultural activities were carried out, and where they took on a systematic, organised form. At the founding session of the AVNOJ on 26-27 November 1942 in Bihać, the Executive

23 Zbornik dokumenata i podataka o narodno-oslobodilačkom ratu jugoslovenskih naroda, vol. II/6: Dokumenti vrhovnog štaba Narodnooslobodilačke vojske Jugoslavije 1942, Belgrade 1957.

24 Marko Miletić and Mirjana Radovanović, 'Lekcije o odbrani: Prilozi za analizu kulturne delatnosti NOP-a', in: Lekcije o odbrani, Prilozi za analizu kulturne delatnosti NOP-a, ed. idem, Belgrade 2016 (KURS \& Rosa Luxemburg Stiftung Southeast Europe), p. 31.

25 Gal Kirn, 'On the Specific (In)existence of the Partisan Film in Yugoslavia's People's Liberation Struggle', in: Partisans in Yugoslavia: Literature, Film and Visual Culture, Miranda Jakiša and Nikica Gilić (eds.), Bielefeld 2015, p. 211. 
Committee passed a decree on the temporary management of the Theatre of People's Liberation. This was the new state's first cultural institution and its director the writer Ivo Frol. The head of the drama section was the actor Vjekoslav Afrić, while Nikola Popović was declared head of the acting school, with the ballet dancer Žorž Skrigin leading the ballet department. Prior to the war, Skrigin had been a performer at the Croatian National Theatre in Zagreb. He was also one of the most prominent Partisan photographers. ${ }^{26}$ The theatre's music department was led by Nikola Hercigonja, with Oskar Danon as conductor. ${ }^{27}$

It is widely believed that the first Partisan exhibition of photographs in Croatia was organised in Otočac on 11 June 1943. However, I came across contrary information claiming that the first Partisan photographs to go on exhibit did so in Slunj on 23 December 1942, at an exhibition of photographs and print ${ }^{28}$ organised by the Agitprop District Committee of the Communist Party of Croatia and the Central Committee of the Communist Party of Croatia. ${ }^{29}$ The exhibition held one year later at the Otočac youth centre featured Partisan brochures, news-sheets, caricatures, pictures by Vladimir Kristl, Vilim Čerić and Ivo Kušanić, and photographs by Franjo Mosinger. After Otočac, the exhibition travelled to Senj, Novi Vinodolski and Crikvenica, where it went on show in the gymnastics hall of the local branch of the Sokol Society. ${ }^{30}$

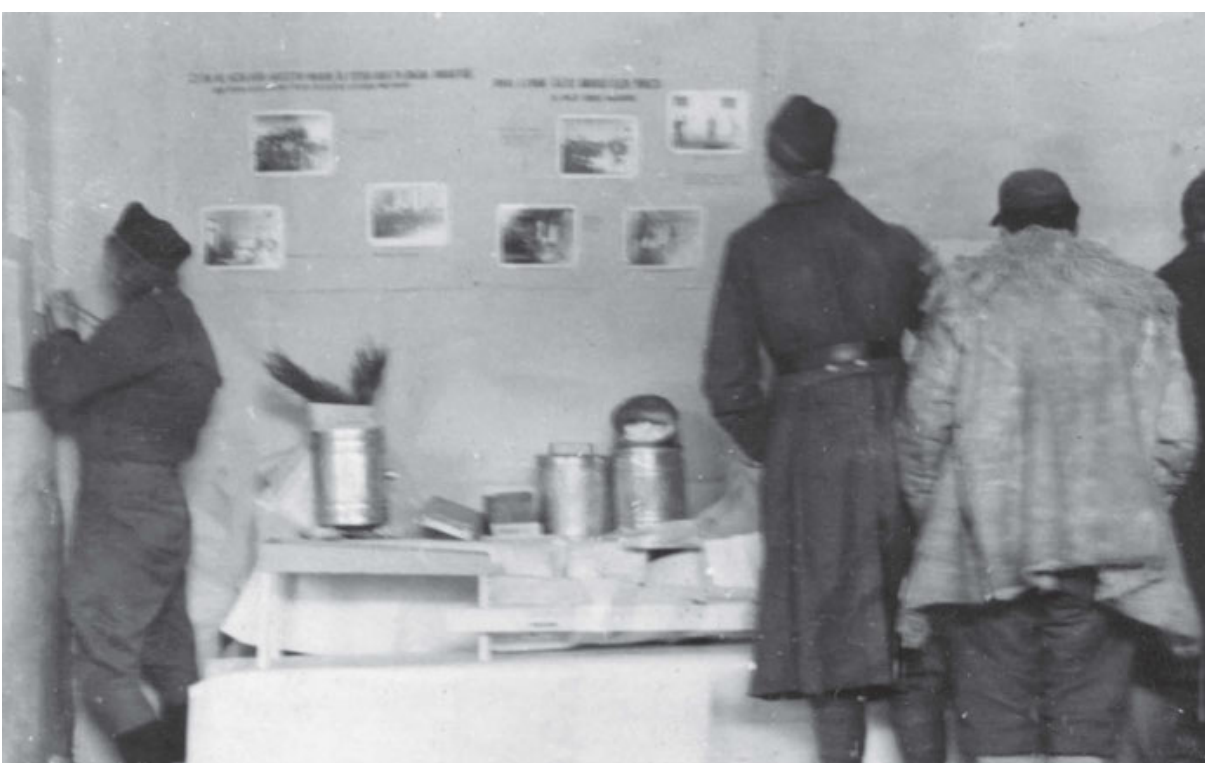

Exhibition of Partisan photography to mark the Second Session of the AVNOJ, Theatre of People's Liberation, Livno, 27 November 1943. Photographer unknown. Croatian History Museum, HPM/MRNH-F-5379.

\footnotetext{
26 Georgij Skrigin was born on 4 August 1910 in Odessa and acquired the nickname Žorž over time. I have chosen to use the moniker 'Žorž Skrigin' as he himself wrote his name like this in the post-war period.

27 Branko Petranović, Istorija Jugoslavije 1918-1988, vol. 3: Socijalistička Jugoslavija 1945-1988, Belgrade 1988 , p. 366.

28 Mane Borcić, 'Kulturno-prosvjetna i propagandna djelatnost u kotarevima Slunj i Veljun tokom NOR-a', in: Kotar Slunj i kotar Veljun u NOR-u i socijalističkoj izgradnji, vol. 2, Đuro Zatezalo (ed.), Karlovac 1988, p. 758.

29 Croatian Institute of History (former Institute of the History of the Labour Movement of Croatia, AIHRPH), KP-220/4890.

30 Hlevnjak/Ivanuš 2008 (see note 18), p. 117.
} 


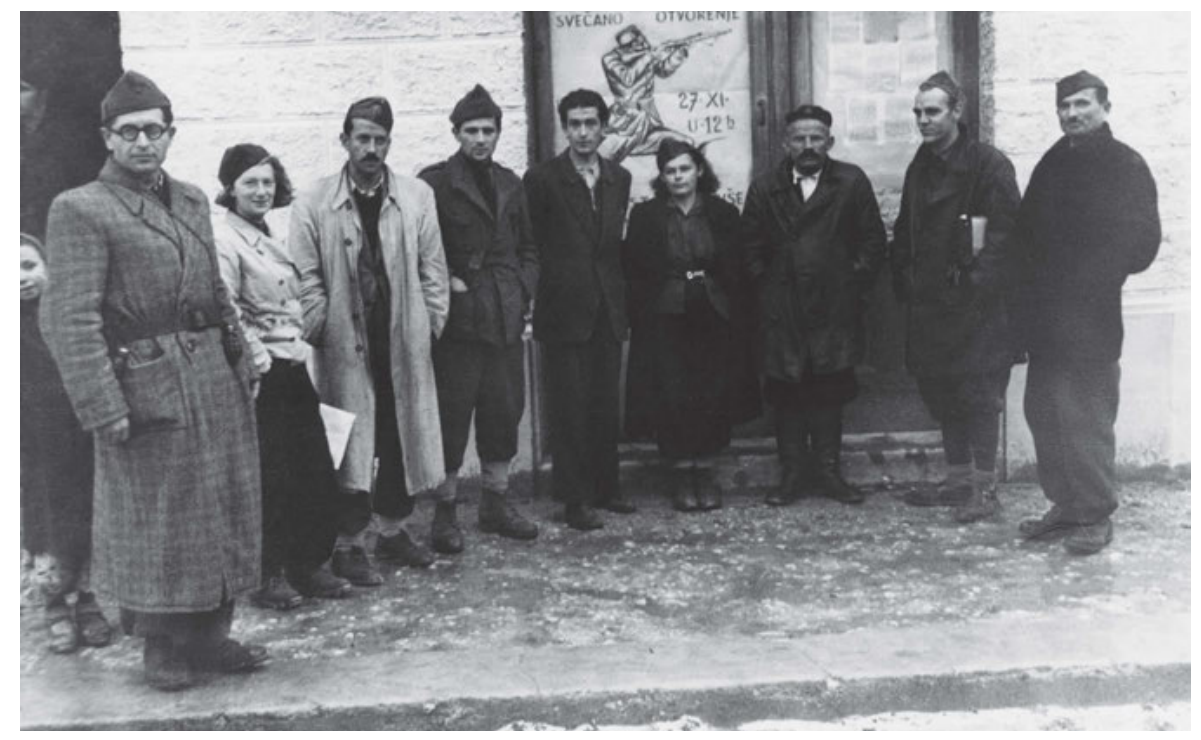

Delegates from Slovenia in Livno on their way to the Bosnian town of Jajce, standing at the entrance to the exhibition of Partisan photography dedicated to the delegates, November 1943. Photographer unknown. History Museum of Bosnia and Herzegovina, FNOB 724.

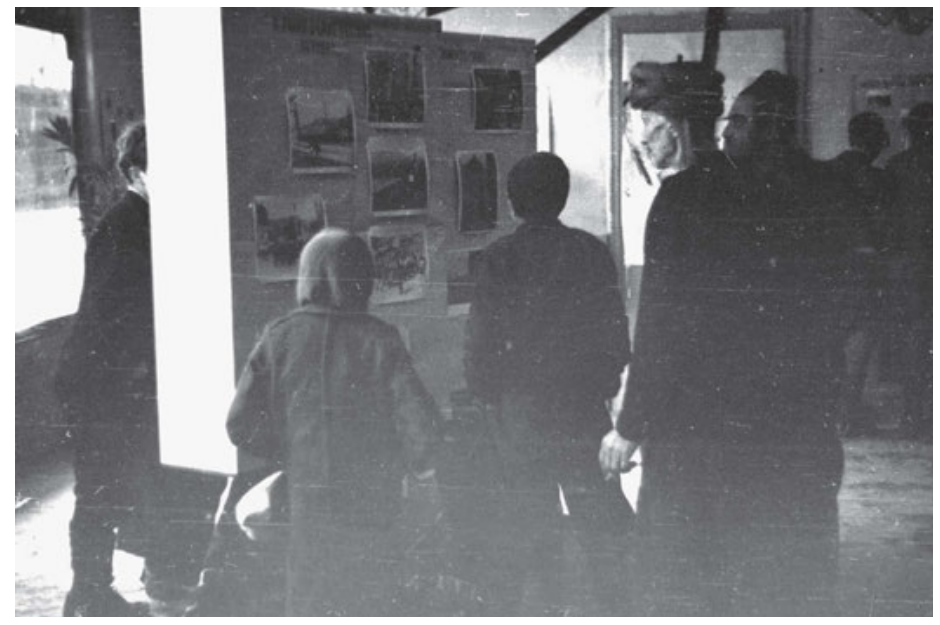

Installation view of one section of the Partisan photography exhibition, held in Livno in honour of the Second Session of the AVNOJ. Photographer unknown. Museum of Yugoslavia, MRNJ III-266.

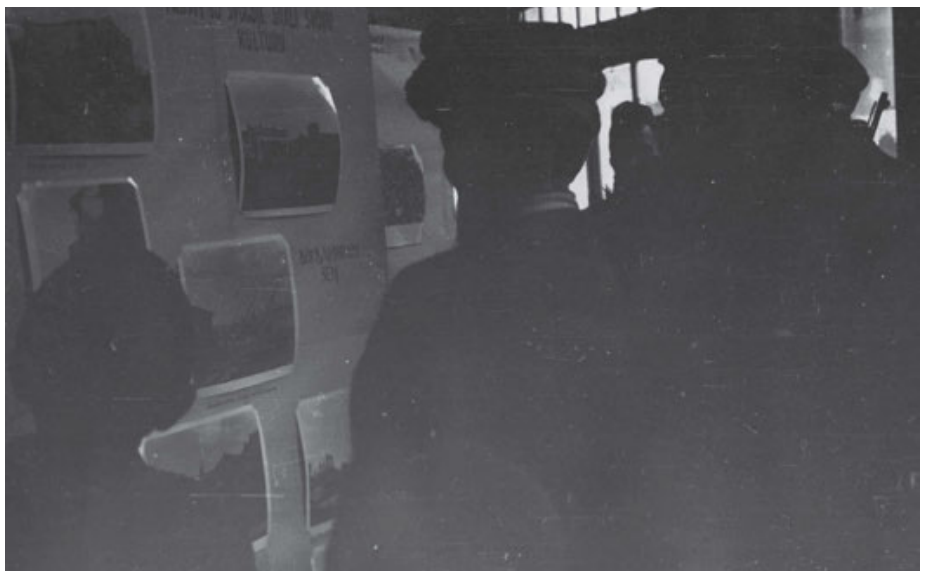

Installation view of Partisan photography exhibition, Livno 1943. Photographer unknown. Museum of Yugoslavia, CKSKJ/MRNJ III-1807. 


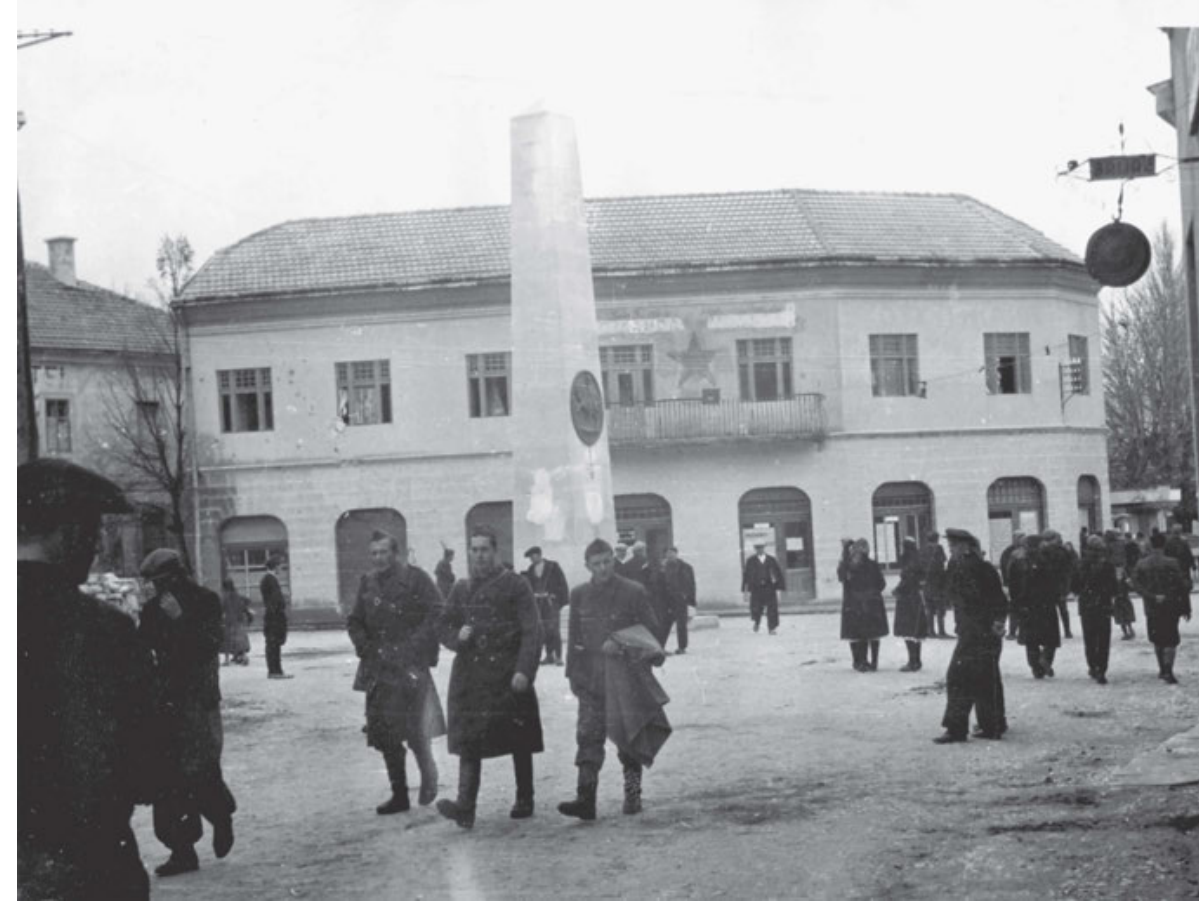

A group of Partisans on the street in Livno, 1943. Photographer unknown.

Museum of Yugoslavia, MRNJ III - 3116.

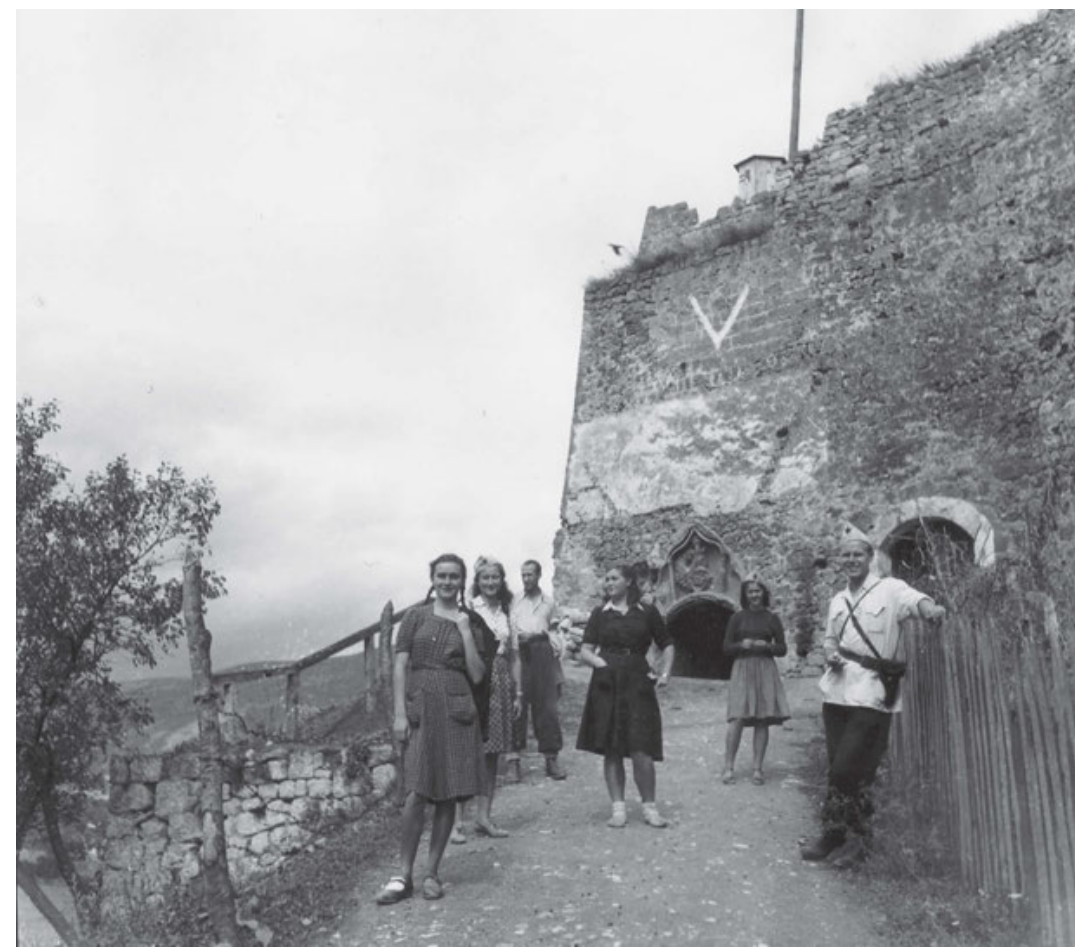

Members of the Theatre of People's Liberation of Yugoslavia in Jajce: Nada Borozan (foreground, left), Mira Afrić, Žorž Skrigin, Jože Rutić, Mira Đerić, Dara Lončar, Vjekoslav Afrić (right), September 1942. Photo: Žorž Skrigin. Museum of Yugoslavia, MRNJ- III - 3459. 


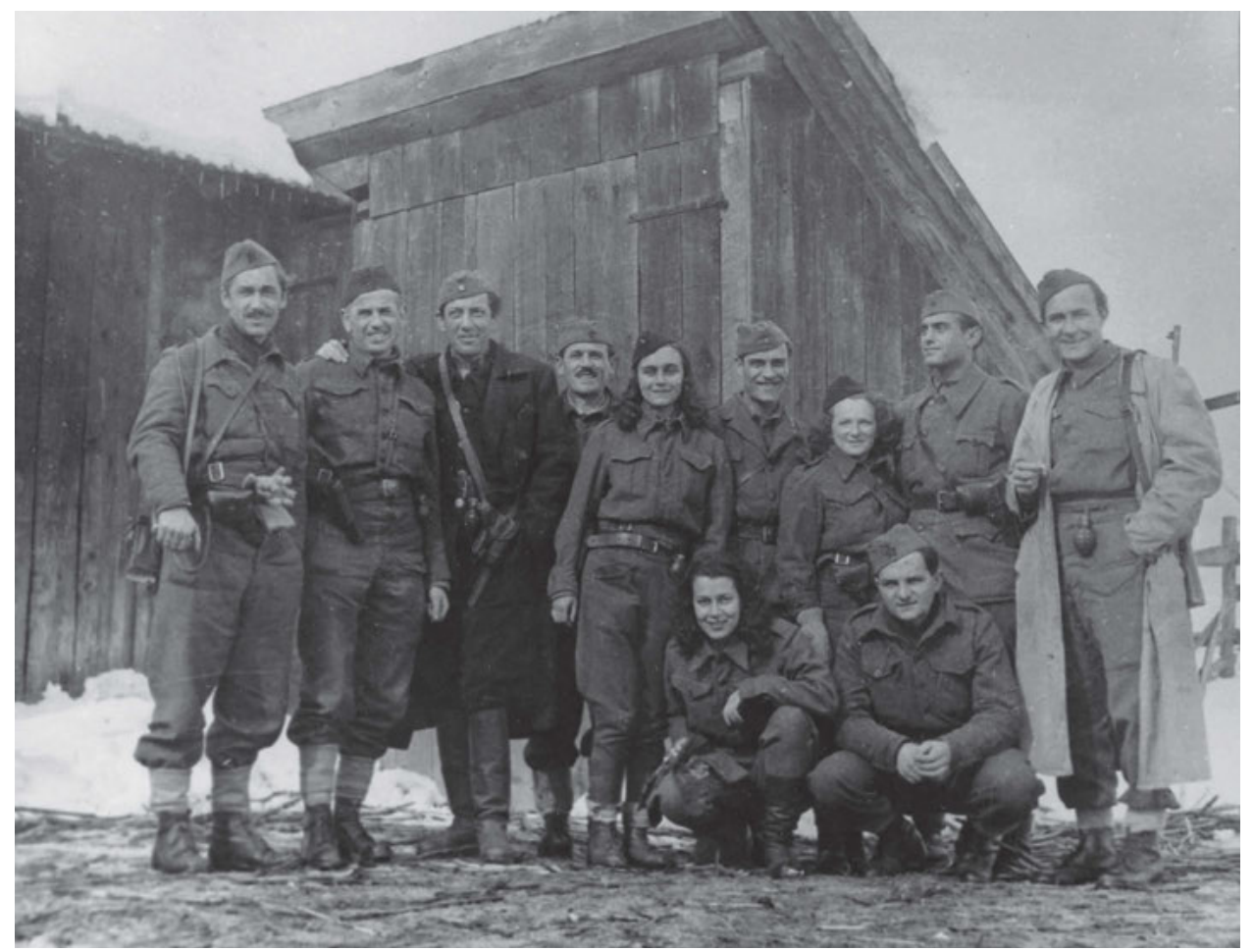

Theatre of People's Liberation at Kozara, December 1943. Photo: Žorž Skrigin (far left). History Museum of Bosnia and Herzegovina, FNOB 6485.

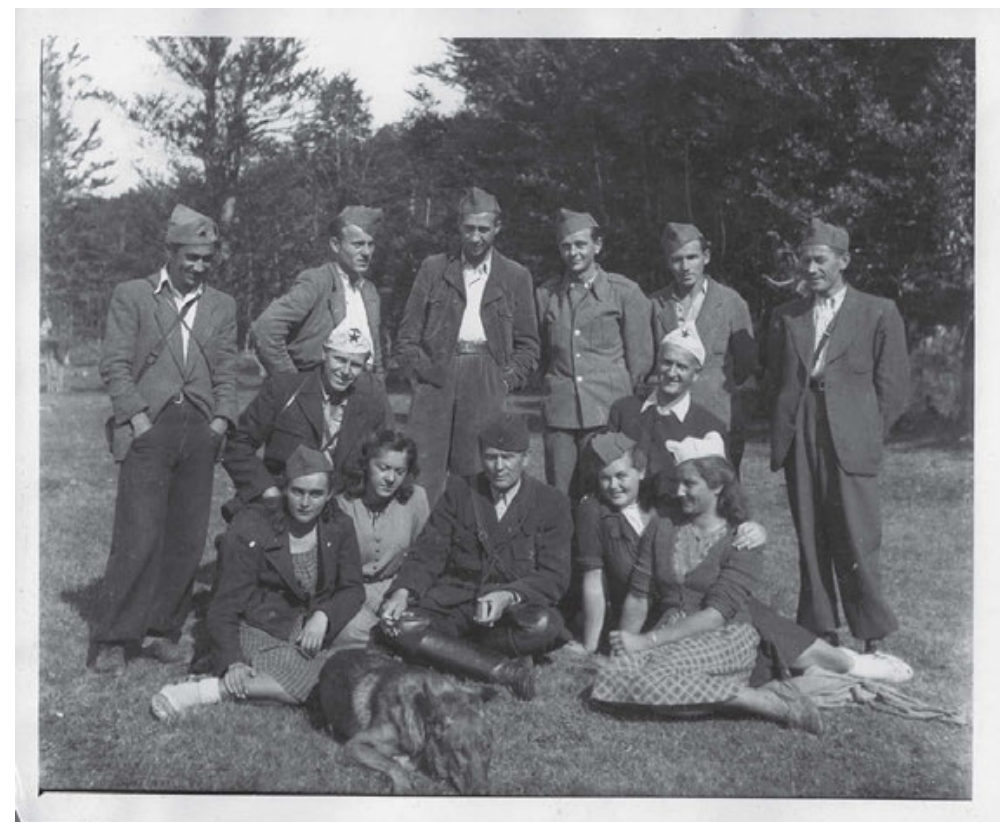

Josip Broz Tito with members of the Theatre of People's Liberation in Mlinište, September 1942. Left of Tito: Mira Đerić and Mira Afrić right of Tito: Nada Borozan and Dara Lončar; kneeling: Vjekoslav Afrić and Milan Vujković; standing: Žorž Skrigin with unidentified theatre members. Photographer unknown. Museum of Yugoslavia, III-1249. 


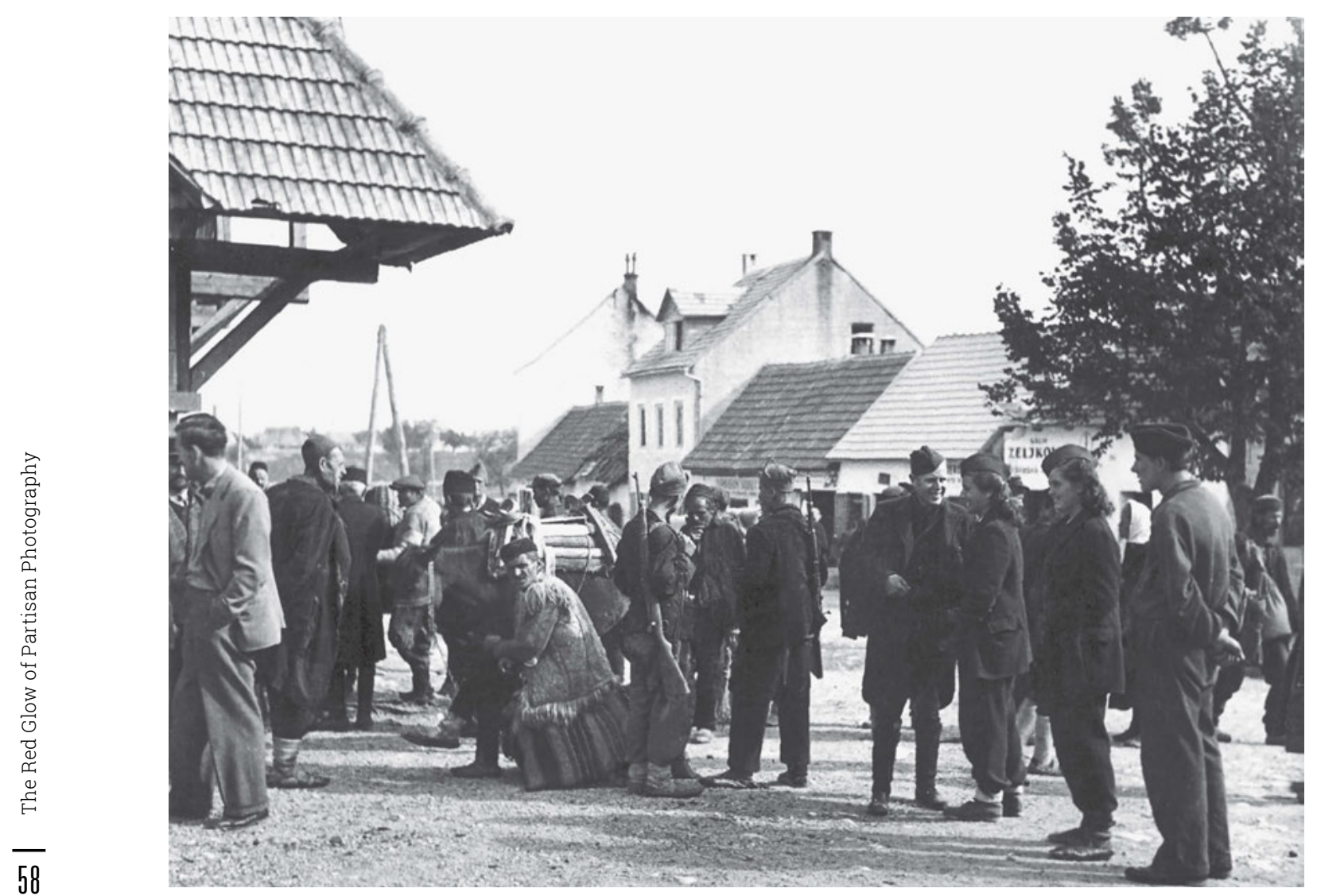

Members of the Theatre of People's Liberation of Yugoslavia, including Mira Afrić, Vjekoslav Afrić and others, in liberated Glamoč on a market day sometime in 1942. Photo: Žorž Skrigin. Museum of Yugoslavia, III-3428.

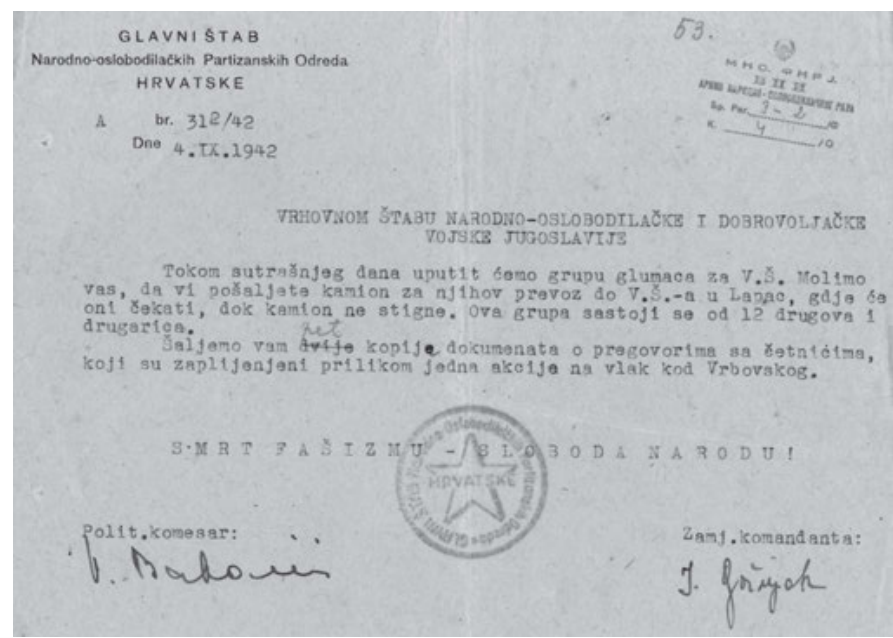

General Staff of the People's Liberation Movement of Croatia requests that Supreme Command provides transportation for actors. Military Archive Belgrade, K4 F2 


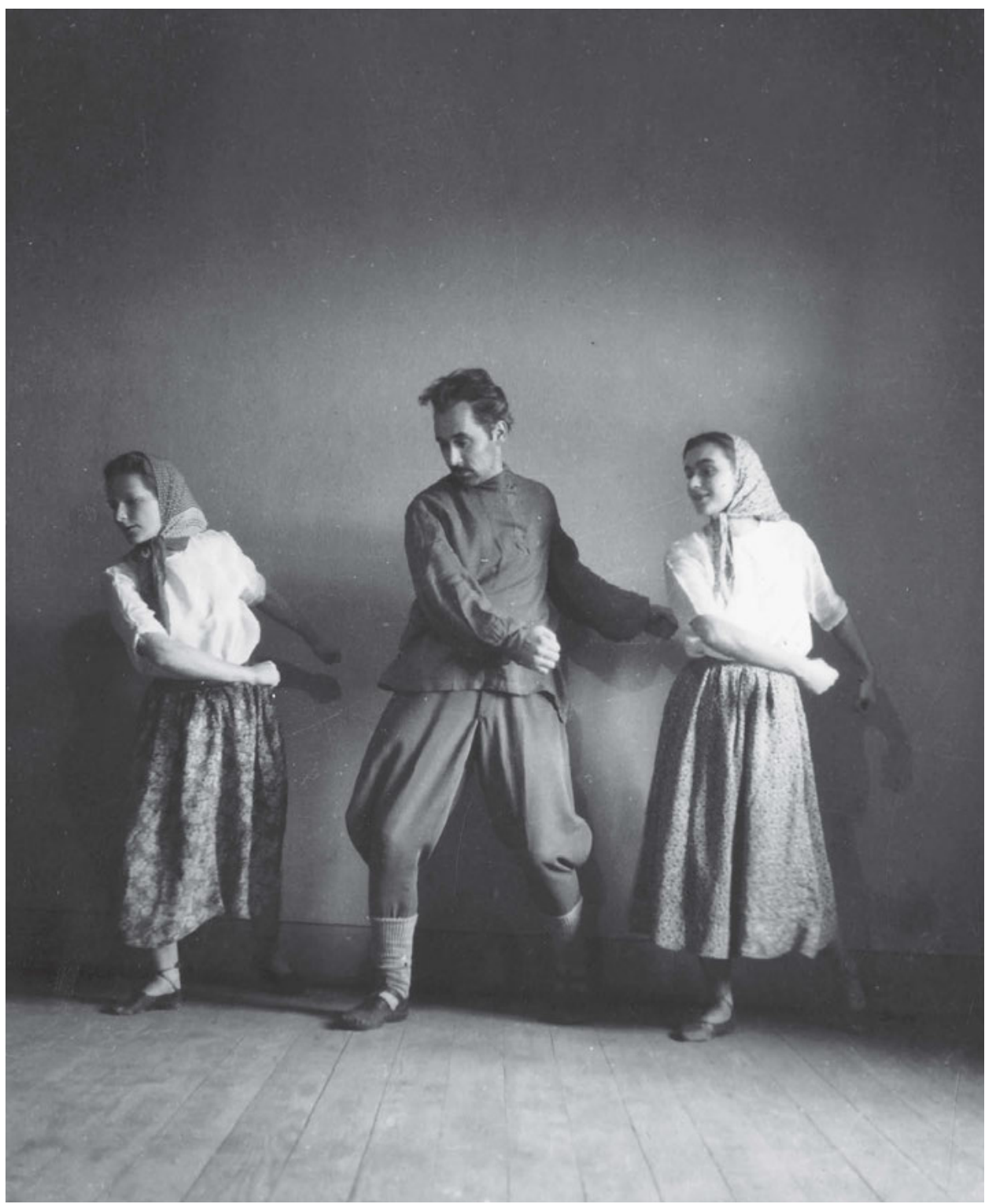

Anika Radošević, Žorž Skrigin and Nada Borozan of the Theatre of People's Liberation of Yugoslavia rehearsing for a ceremony honouring the Second Session of the AVNOJ in Jajce, 1943. Photo: Žorž Skrigin. Museum of Yugoslavia. 


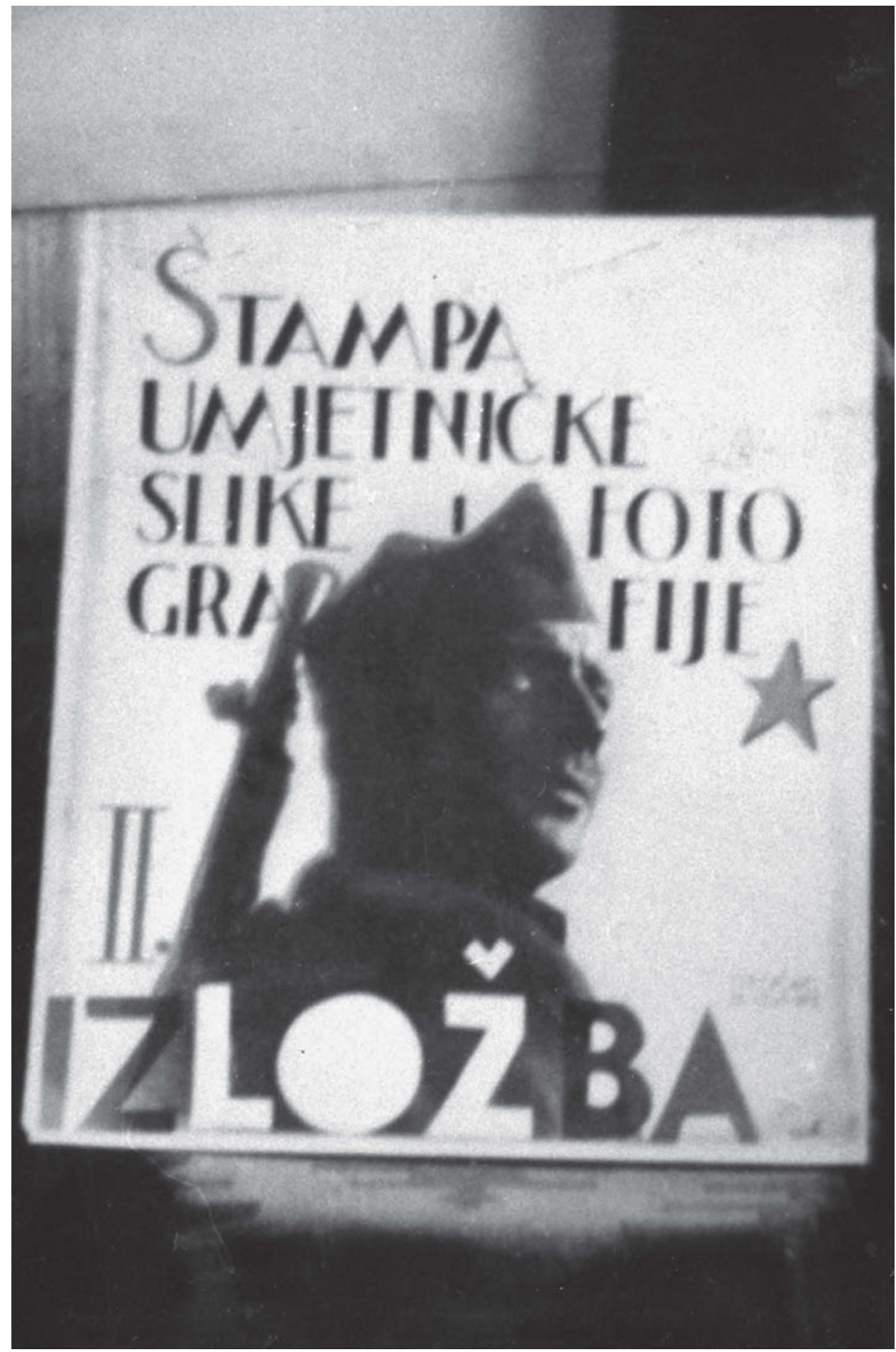

Poster for the Second Exhibition of Pictures and Photographs, Otočac, 11 June 1943. Photo: Franjo Mosinger. Croatian History Museum, HPM/MRNH-F-3427. 


\section{Sic Transit Gloria Mundi: An Actor and a Ballet Dancer as Partisan Photographers}

Vjekoslav Afrić's final role at the Croatian State Theatre was playing the eponymous hero in Faust. The post-war Croatian director Slobodan Šnajder used Afrić in this role as a template for his 1980s play Hrvatski Faust (Croatian Faust), which continues to disturb audiences to this day. The fictional figure of Afrić and the Croatian National Theatre in its present-day form (located on a square that was until recently named Trg maršala Tita: Marshal Tito Square) reveal ideologically charged memories at odds with attempts at collective forgetting. Afrić's 1942 diary entry continues to be relevant today, as it hints at the theatre's social role and speaks of the people in the audience, and of art's emancipatory action:

Liberated Partisan territory was unimaginable without an intense cultural and artistic life. Alongside the formation of the first military units, the first literacy courses, schools, libraries, news posters, print and photo exhibitions, teaching courses and newspapers were organised. Ultimately, almost every larger military unit wanted to have its own art and culture group. Every village in the liberated territory also had its own amateur art and culture group. They sang folk and Partisan songs, played folk games, organised performances, staged dramas, recitations, organised cultural and social evenings [...]. The Lika audience was extremely interested in our performances; we often performed in front of audiences of several thousand people. If news got out that we were holding an event in a certain village, even villagers from surrounding places some distance away would flock to hear the Zagreb actors. There were even audiences from Axis-occupied territory, for whom leaving the territory to attend our performances was a special feat undertaken at great risk. ${ }^{31}$

In the same year, Afrić and Žorž Skrigin began preparations for the theatre production of Branislav Nušić's play, Sumnjivo lice (A Suspicious Character). They established the first Partisan ballet, Okupator (Occupier), featuring, besides Skrigin himself, the wonderful Anika Radošević, along with Nada Borozan, a brilliant dancer, and Dara Tatalović, with the poet Junus Međedović appearing in an acting role. One of Afrićs diary entries written after a performance of Sumnjivo lice on 23 November 1942 (performed before an audience consisting of seventy captured Ustashe-controlled Croatian Home Guards) is telling of the power of Afrićs mind. It also speaks of his spiritual condition and that of his colleagues, and to his position as a cultural worker who left the comfort of the city for a life in the forests with the Partisans. In this situation, reality was much more interesting than art. At a moment in history when life and the stage had swapped places, the performers were compelled to reconsider their role and face those who, unlike them, had been prepared to collaborate: 
They cheered and applauded as if they were Partisans. There were also a few people from Zagreb known to us among them. After the performance they informed us in detail about the opportunities available in Zagreb, especially in Zagreb theatre. Among these familiar names was also the brother of a ballerina well known to us. He, it was understood, knew all the gossip, intrigue and inside news on the theatre scene. He updated us on every twist and turn in the situation in Zagreb theatre after we had left. Afterwards, I thought a lot about his news, and it was unbelievable how this environment that I had left had now become so alien to me, after being so familiar just a few months ago. Is it really possible that, even today in the middle of the biggest war and revolution, some people can sit peacefully in a restaurant, throw parties at home, act on a stage for an audience that includes occupiers, earn a little something on the side as the musical entertainment at soirées and cabaret performances, chat about gossip and backstage scandals, have flings, speak and recite over announcements on the radio, over the same radio that spouts the biggest lies and abominations, that shamelessly tricks and deceives the entire population, that screams the occupiers' praises and flaunts as loudly as possible their lack of humanity and brutality? Can I, dare I understand all this? If I understood, I would also have to forgive. And what am I supposed to understand? Are they really cut from a different cloth than we are and thus unable to opt for a life like ours? [...] I look at the members of the Home Guard - What? Should I pity them? Should I scorn them? Should I try and understand them? What should I think about my good and respected colleagues in Zagreb? And the more I think about them, the more I feel like this entire psychological process of mine has been turned upside down. Just like in a camera. Instead of understanding them to love them, I love them, and in so doing, I begin to understand them. When this war is over and if we're still alive, and they are too, we'll sit down together in a restaurant or at a party in someone's home and we'll talk about our experiences. They'll talk about their acting successes, affairs and gossip, and we'll talk about our war experiences and [...] draw a line under everything. We will be of interest to each other once again. 'Sic transit - Gloria Swanson!' as my friend Dubajić would say. ${ }^{32}$

Sic transit gloria mundi (So passes the glory of the world) is Afrićs act of forgiveness to his colleagues, his reconciliation, the supreme gesture of an intellectual, artist and revolutionary rejecting privileges in favour of his own political being and political action, and thereby circumventing Gramscian hatred of a lack of determination in others. Afrić also emphasises his critical review of the role of art itself and the Theatre of People's Liberation, emphasising that within the Partisan movement different, often diametrically opposed attitudes towards art prevailed..$^{33}$ This reveals to us a dilemma freed from the dogmatism and moralising that characterises present-day attempts to represent the entire Partisan period in a new light. Uninterested in the limelight or in acting fame, rather than becoming a cynic Afrić serves as an engaged cultural worker who continues to examine the conditions in which he works. From the same diary, we also learn that during Afrić's time in the Partisans, he used a camera that he brought with him from Zagreb, along with several rolls of film, when he left with a group of work colleagues on 22 April 1942. The first group also included Ivka and Joža Rutić and Salko Repak. Milan Vujnović, Zvonimir Cvija and Žorž

\footnotetext{
32 Vjeko Afrić, 'Sa Kazalištem narodnog oslobođenja u Bihaću', in: Bihaćka republika, vol. 1, Nataša Todorović (ed.), Bihać 1965, pp. 513-514.

33 Ibid., p. 525.
} 


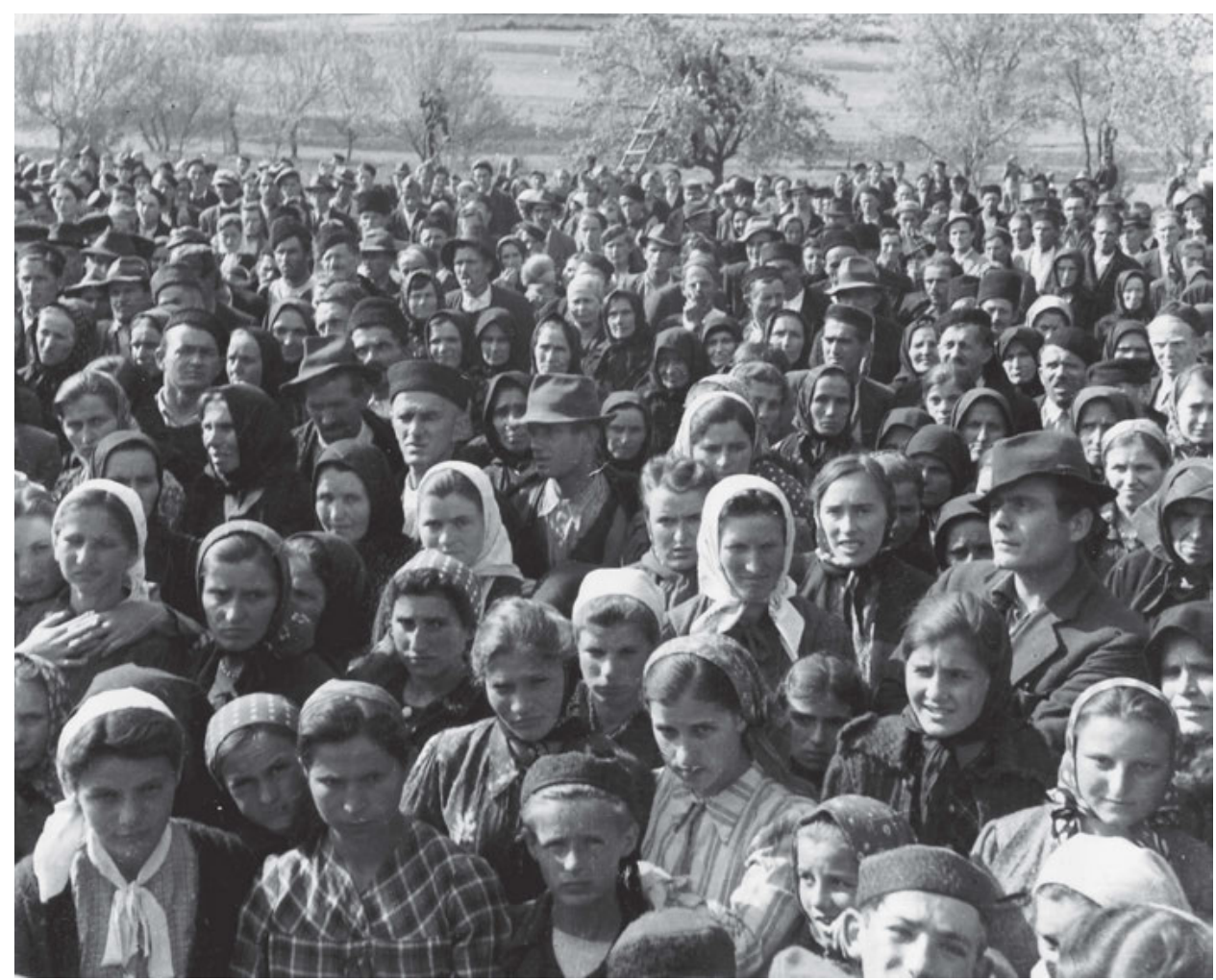

Audience of performance by the Theatre of People's Liberation of Yugoslavia, Lika 1942. Photo: Žorž Skrigin. Museum of Yugoslavia, MRNJ III - 3716.

Skrigin were in a second group that left Zagreb the same day. ${ }^{34}$ Upon leaving his Zagreb flat, Žorž Skrigin destroyed one set of his photographs, out of fear that in the hands of the Ustashe, the images might compromise people close to him. He carried several rolls of film with him, and a Rolleiflex camera that he used during his time in the Partisans.

Before the war, Žorž Skrigin had been a prominent member of Fotoklub Zagreb and one of the top prizewinning photographers in the country and on the international stage. While in the Partisans, he was responsible for some of the movement's most important images. In following the First Croatian Proletarian Brigade on the move towards the coast, Skrigin took art photographs at Plitvice Lakes, before later taking the first photographs of combat too. On the road that linked Senj and Novi Vinodolski on the Croatian coast near the island of Krk, the Partisans prepared an ambush at the point where the road passed between the hills and the sea. The brigade's commander, Milan Žeželj, was involved in selecting the best place from which to record the action. Skrigin describes these moments thus: 
I set up the camera quickly and got in position so I could photograph as best as possible. The enemy was awfully close by, they were already passing the road beside me - why weren't we firing? I knew that the agreement had been that Banina would give the signal to attack by firing his revolver. Artillery was passing by, then an armoured vehicle - why weren't our forces attacking when this was the best moment to take photographs? I lay motionless so the Italian aide-de-camp couldn't see me; not a sound of human voices, and in the distance just the hum of a motor resounding. All this left me in a state of nervous tension. I was starting to fidget when I suddenly heard a revolver shot, and off the sparkling sea, calm as a mirror, rebounded its loud echo. Confusion broke out. I heard shouts: 'Proletarians advance! Strike!' At that moment I pointed my camera at the attack, when above my head our heavy machine gun shook us, having

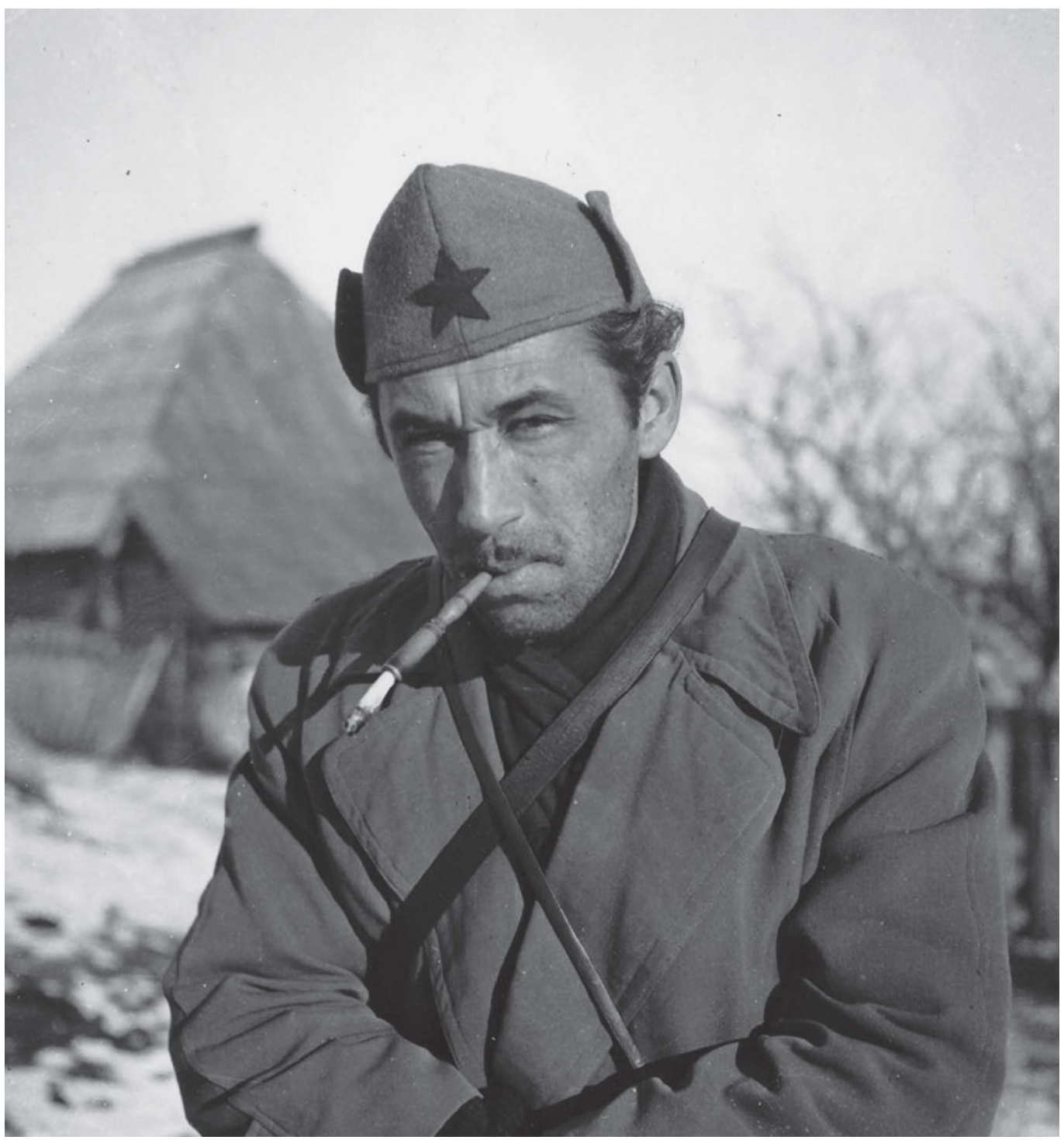

Žorž Skrigin of the Theatre of People's Liberation of Yugoslavia. Photo: Žorž Skrigin. Institute for the History of the Workers' Movement of the People of Yugoslavia, accession no. unknown. 
taken up position a few metres behind me. This was my first mission. Bullets whistled above my head; it was the first time l'd heard anything like this and the first time l'd smelt the scent of gunpowder. Instinctively, I pressed my head to the ground, lower and lower, thinking: What if I'm killed on my first mission - and worse - by one of our own bullets? But then a vanity awoke in me - Am I really unable to record what's happening down there on the road? I turned the Rolleiflex upside down, held my arms above the top of the shelter, and observed the events on the road in the reflex mirror and thought to myself: I only hope our machine gun hits me in the hand rather than in the head! ${ }^{35}$

The Partisan unit suffered no losses in this ambush, while on the Italian side two artillery pieces were destroyed, and three light machine guns, numerous fire arms, thousands of rounds of ammunition and one revolver were seized, with Skrigin subsequently claiming the revolver for himself. ${ }^{36}$ As a member of the Theatre of People's Liberation, under the control of the Supreme Command of the People's Liberation Army and Partisan Detachments of Yugoslavia, Skrigin was well placed as a photographer - he was less exposed to front-line combat and well equipped with photographic supplies. In the Croatian village of Mlinište, he was one of the first to photograph Josip Broz Tito. He was constantly on the move with the main body of the People's Liberation Army and socialised with the poet Ivan Goran Kovačić, whom he photographed right before Kovačićs death in east Bosnia after the Fifth Offensive (Battle of Sutjeska). ${ }^{37}$ His Zagreb war comrade Vjekoslav Afrić saved the text of Kovačić's poem, 'Jama' (The Pit), which he first read publicly to the injured members of the First Proletarian Brigade. In these verses, describing the weight of war and pain, the poet hinted at his own death:

Began to sob and never have ceased yet,

With throat alone, for now I have no eyes;

With heart alone, for my tears the knife

Of murderers has gorged away. I am deprived

Of eyes to see you, and that strength is gone.

But who are you, and whence? I only know

That your light warms me. All - Sing! for I can feel

At last I live; even though I'm dying now,

This in sweet Liberty, with Vengeance stolen

From death. Your singing gives my eyes back light,

Strong as our People, and our sun as bright. ${ }^{38}$

35 Žorž Skrigin, Rat i pozornica, Belgrade 1968, pp. 22-23.

36 Ibid., p. 163.

37 Ibid.

38 Ivan Goran Kovačić, The Pit. Poem, 1943: With plates and concluding remarks by the translator Alec Brown, trans. Alec Brown,

Zagreb 1961. 


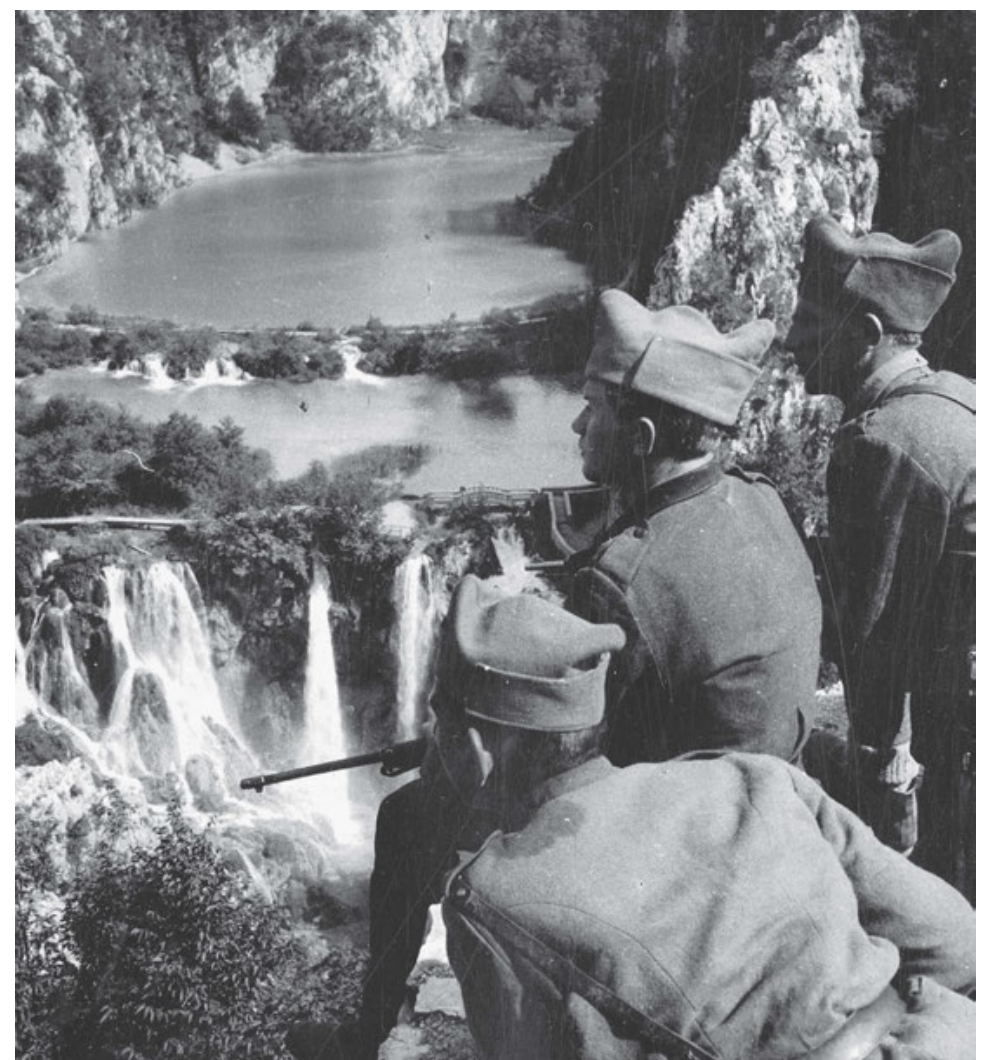

Partisans keeping watch, Plitvice Lakes, 1942. Photo: Žorž Skrigin.

Museum of Yugoslavia, accession no. unknown.

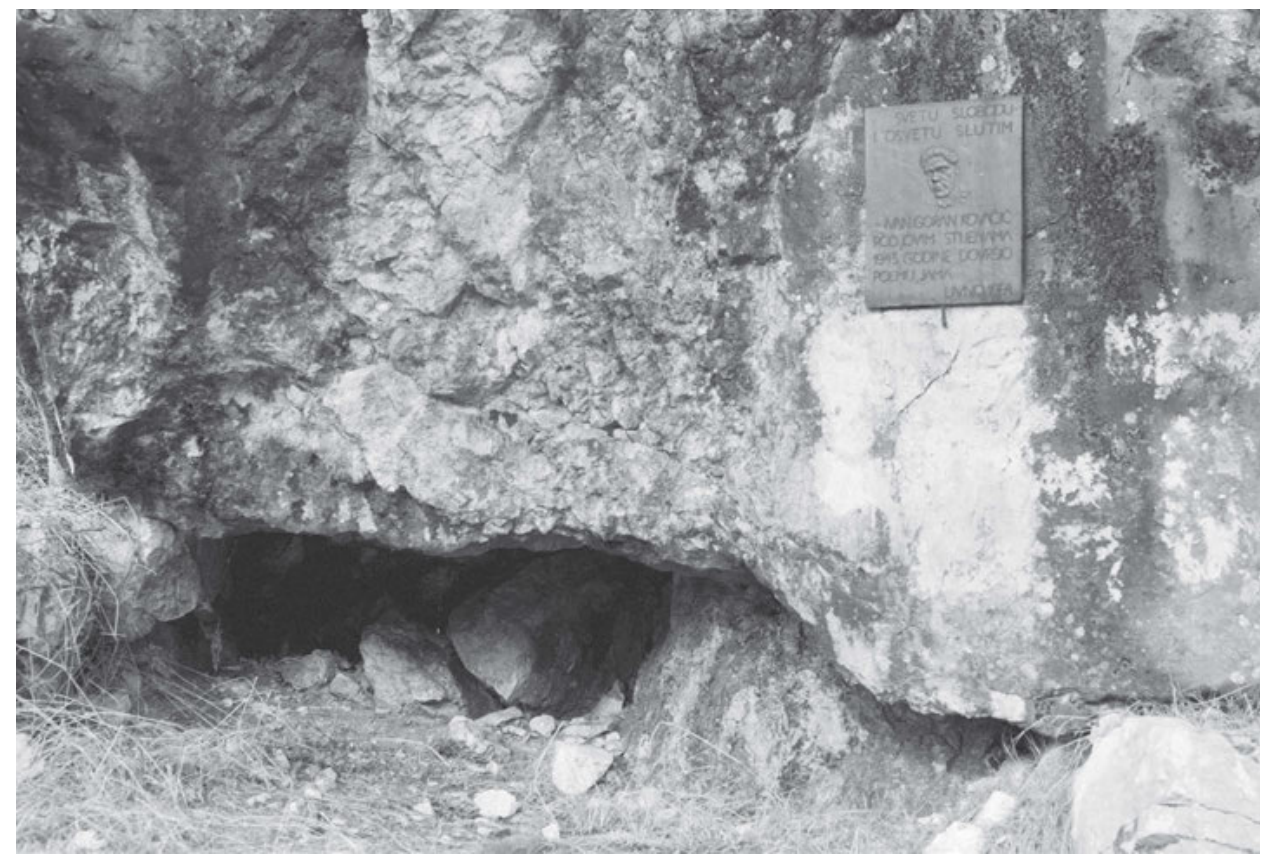

Plaque commemorating spot where Ivan Goran Kovačić finished writing the poem 'Jama', Livno, 2017. Photo: Davor Konjikušić. 
Except for Skrigin who left for the battlefield, most members of Fotoklub Zagreb remained in Zagreb. Milutin Mudrinić-Mudri, a member of the club from 1936 who worked as a teacher of Croatian, Latin and gymnastics - a polyglot who spoke eight languages - was killed together with his oldest son Veljko in Jasenovac in 1943. Just a few of his photographs have survived. He mostly taught literature at the Second Classical Grammar School of Zagreb, ${ }^{39}$ and later at the Third Boys' Secondary School (realna gimnazija). He was well known for cultivating a love of socially engaged phrases among his pupils, saying to them: "Give me your hand, worker!" - Now that's real poetry for you, children, not the dilettante kind $[\ldots]]^{\prime 40}$

\section{The First Group of Cultural Workers in Occupied Europe}

Although postponed a year because of an enemy offensive, the First Congress of Cultural Workers of Croatia was held in the small Croatian town of Topusko from 25-27 June 1944. This was a unique gathering in occupied Europe, of exceptional importance in the development of Partisan photography. As part of the congress, an exhibition of paintings and photographs was held on the evening of 26 June. ${ }^{41}$

In Otočac, the war-photography unit of the propaganda department of the ZAVNOH was formed, ${ }^{42}$ founded by Hugo Fischer Ribarić - a photographer from Crikvenica, together with Elvira Kohn and Đurđa Koren (née Šipušić), who were among the few female Partisan photographers. Other members of the unit included the journalist and publicist Mahmud Konjhodžić, film lab technician Slavica Biluš and graphic designer Karlo Nađ. ${ }^{43}$ Ribarić was responsible for leading the propaganda department at the ZAVNOH.

The Partisan Mladen Iveković also took photographs to document the activities of the ZAVNOH. He was a well-known lawyer and pre-war member of the Communist Party of Yugoslavia from 1934. He helped set up the newspaper Pregled and was a member of the editorial board of Novi list, Odjek and Naše novine. Early in the war, in January 1942, he was imprisoned in Jasenovac concentration camp. The Partisans managed to get him released, however, in a prisoner exchange eight months into his incarceration. As a member of the AVNOJ Executive Committee, the main editor of the daily Vjesnik and head of the propaganda department of the ZAVNOH, Iveković had the opportunity to take photographs all over Croatia and in Bosnia and Herzegovina. His photographs of Vladimir Nazor, Dr Ivan Ribar and Ivan Goran Kovačić deserve a special mention. The selection staff of the photo-

39 HDA (Croatian State Archives), collection 216 (MNP NDH), box. 680, no. 8693.

40 Pavle Jakšić, Nad uspomenama, vol. 1, Belgrade 1990, p. 49.

41 Prvi kongres kulturnih radnika Hrvatske, Topusko, 25-27 June 1944. ČSP, 8/1976. no. 2/3, 16-17; see also Drago Roksandić, 'Prvi kongres kulturnih radnika Hrvatske (Topusko, 25.-27. lipnja 1944): Iskustvo i aproprijacije', in: Intelektualci i rat $1939-1947$. Zbornik radova s Desničinih susreta 2011, Drago Roksandić and Ivana Cvijović Javorina (eds.), Zagreb 2012, p. 112.

42 Dušan Graovac, 'Organizacija i djelatnost NOO-a u Lici između Drugog i Trećeg zasjedanja ZAVNOH-a', in: Treća godina Narodnooslobodilačkog rata na području Karlovca, Korduna, Like, Pokuplja i Žumberka, Đuro Zatezalo (ed.), Karlovac 1977, p. 745.

43 Branka Hlevnjak and Rhea Ivanuš, Hrvatska antiratna fotografija: Prvi svjetski, Drugi svjetski i Domovinski rat. Zagreb: Udruga za

promicanje oblikovanja i umjetnosti, Ljubljana 2008, p. 113. 


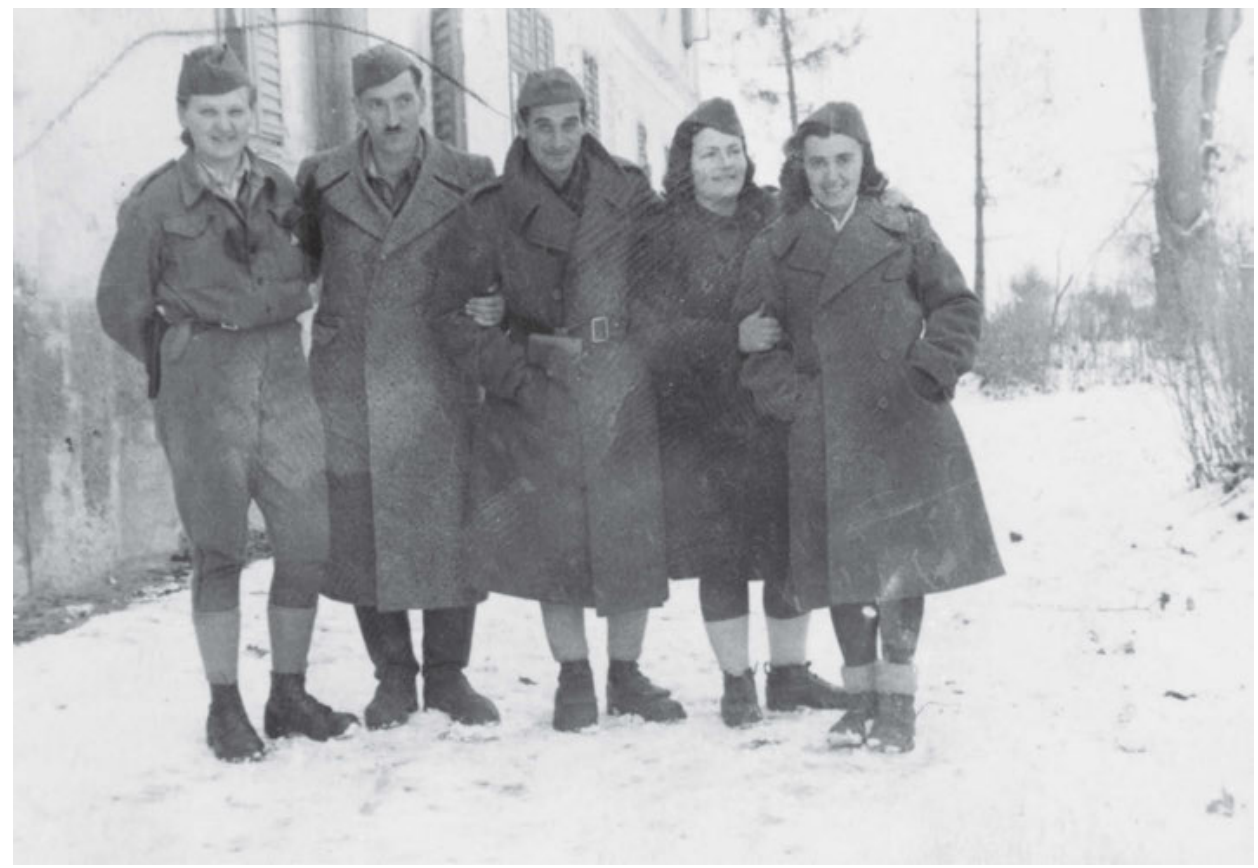

Members of the photography unit of propaganda department at ZAVNOH: Đurđa Koren (left), Karlo Nađ, Hugo Fischer Ribarić, Slavica Biluš and Elvira Kohn (right), Topusko, Autumn 1944. Croatian History Museum, HPM/ MRNH-A-2602-f33-27a.

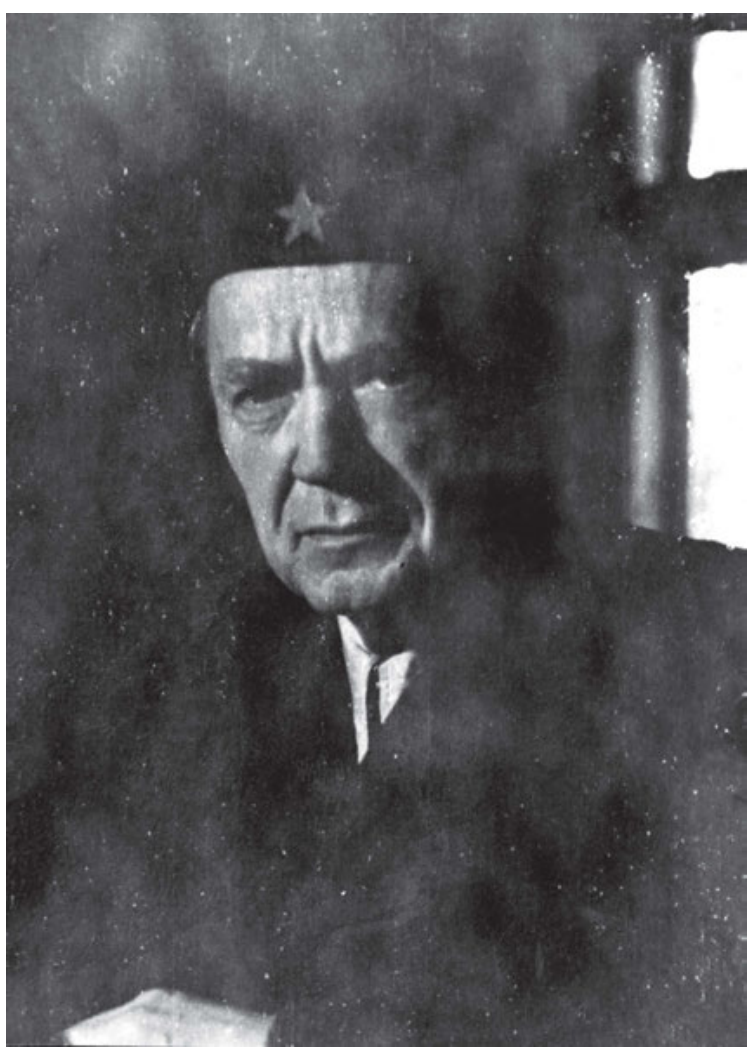

Dr Ivan Ribar, chairman of the AVNOJ. Otočac, 1943. Photo: photography unit at ZAVNOH. Croatian History Museum, HPM/MRNH-A-2601-f90-30. 
graphy exhibition in Topusko faced numerous problems because the photographs were not sorted by theme and lacked captions. Recently taken images from the session of the Croatian ZAVNOH and the Unitary People's Liberation Front were missing. They lacked basic equipment and an enlarger, which Hugo Fischer Ribarić had supposedly left in a hideaway. ${ }^{44}$

A similar congress had been held in the town of Hvar two years before. That conference, held on 19 December 1942 for the cultural workers of Dalmatia, was organised for authors, composers, architects and artists. As the ZAVNOH developed further, at its third session it set up departments for administration and law, public health, the economy, education, social politics and propaganda - organised along the lines of the People's Liberation Committees, from the county level upwards. ${ }^{45}$ This laid the foundations for the post-war emergence of regional Museums of the People's Liberation. On 3 September 1944, all area and district-based People's Liberation Committees received an order demanding that they gather materials for museum displays, including photographs they considered of special significance. ${ }^{46}$ The prominent art historian and then curator of the Archaeological Museum in Split, Cvito Fisković, invited people at the newspaper Slobodna Dalmacija to begin gathering everything from water pipes and medical supplies to photographs. ${ }^{47}$

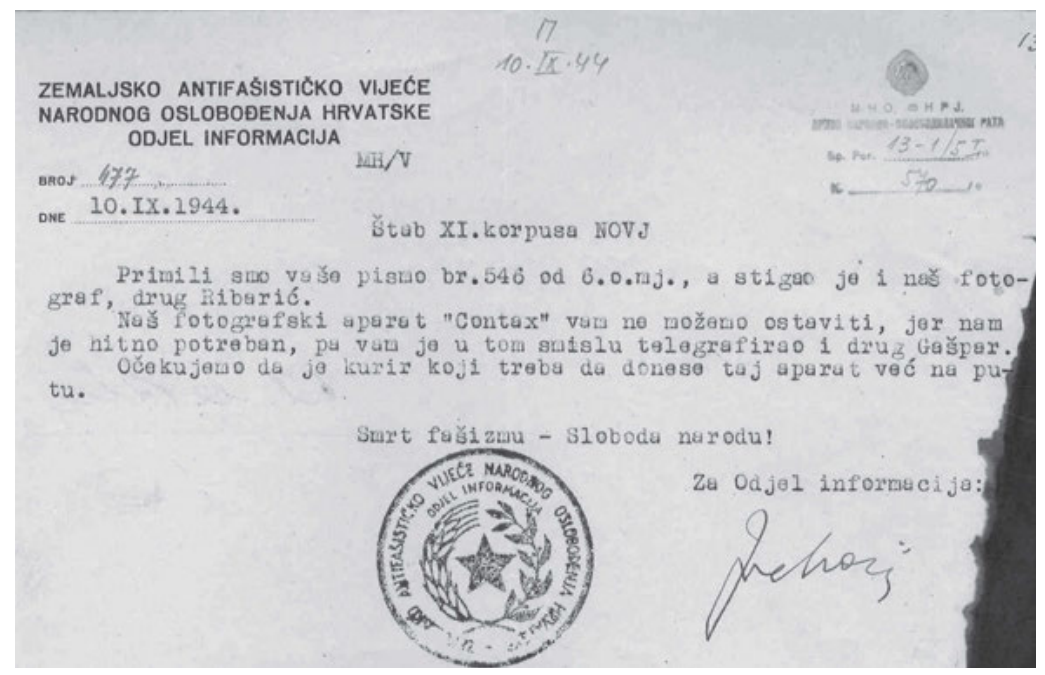

Dispatch from ZAVNOH to the Sixth Corps of the People's Liberation Army of Yugoslavia about the lack of photographic equipment. Military Archive Belgrade, NOVJ-K570 F5i 13.

44 HDA (Croatian State Archives), ZAVNOH II/Propaganda Department (Information Section), June 1944, box. 30/206, NV32/2905; see also Roksandić 2012 (see note 41), p. 115.

45 Sabor u Topuskom. Treće zasjedanje Zemaljskog antifašističkog vijeća narodnog oslobođenja Hrvatske, Zagreb 1945, p. 51.

46 Zemaljsko antifašističko vijeće narodnog oslobođenja Hrvatske, zbornik dokumenata 1944, Zagreb 1975.

47 Vladimir Dedijer, Dnevnik III 1941-1944, Rijeka 1981, p. 204. 


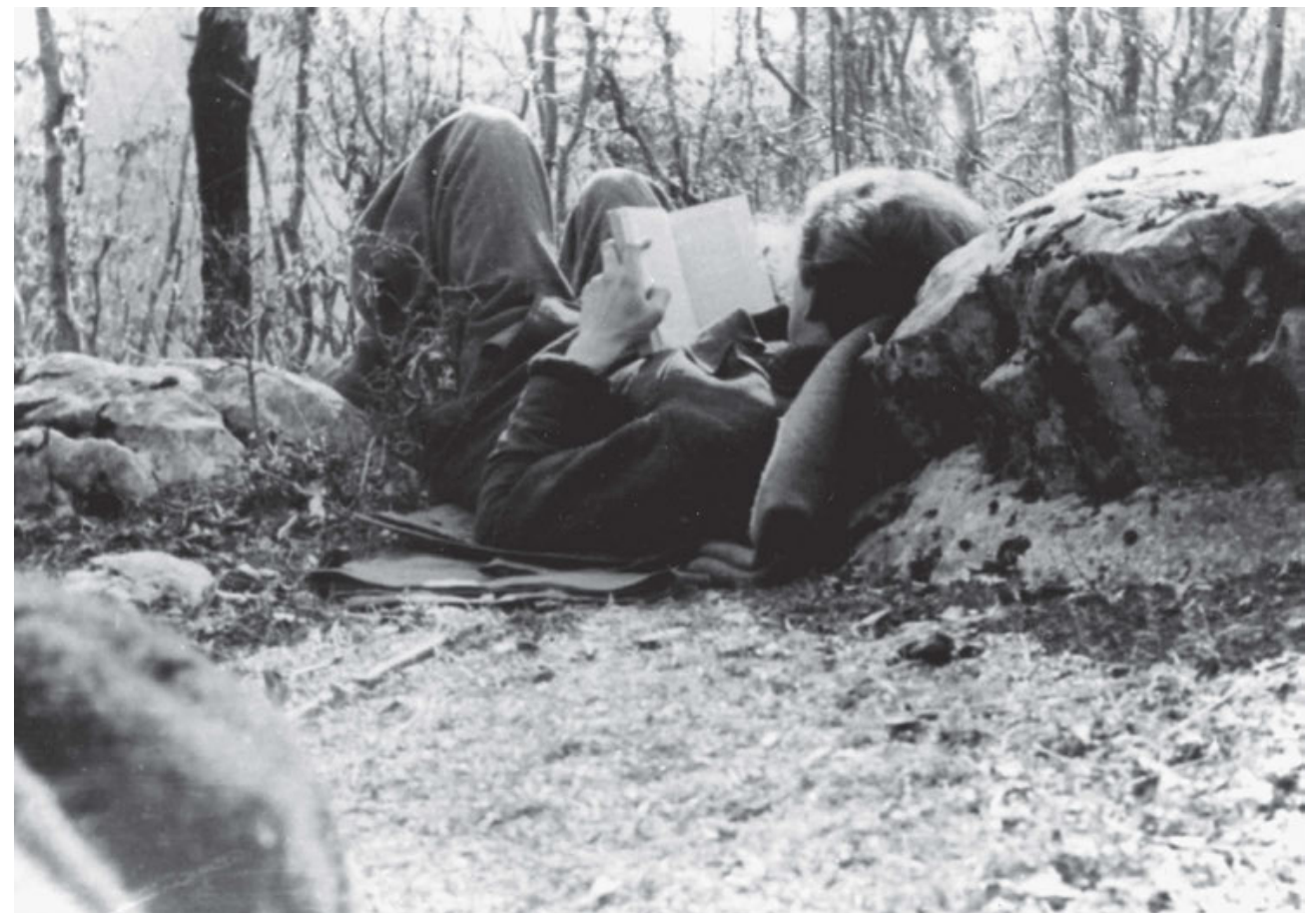

The poet Ivan Goran Kovačić reading. Photo: Mladen Iveković. History Museum of Bosnia and Herzegovina, FNOB 6440.

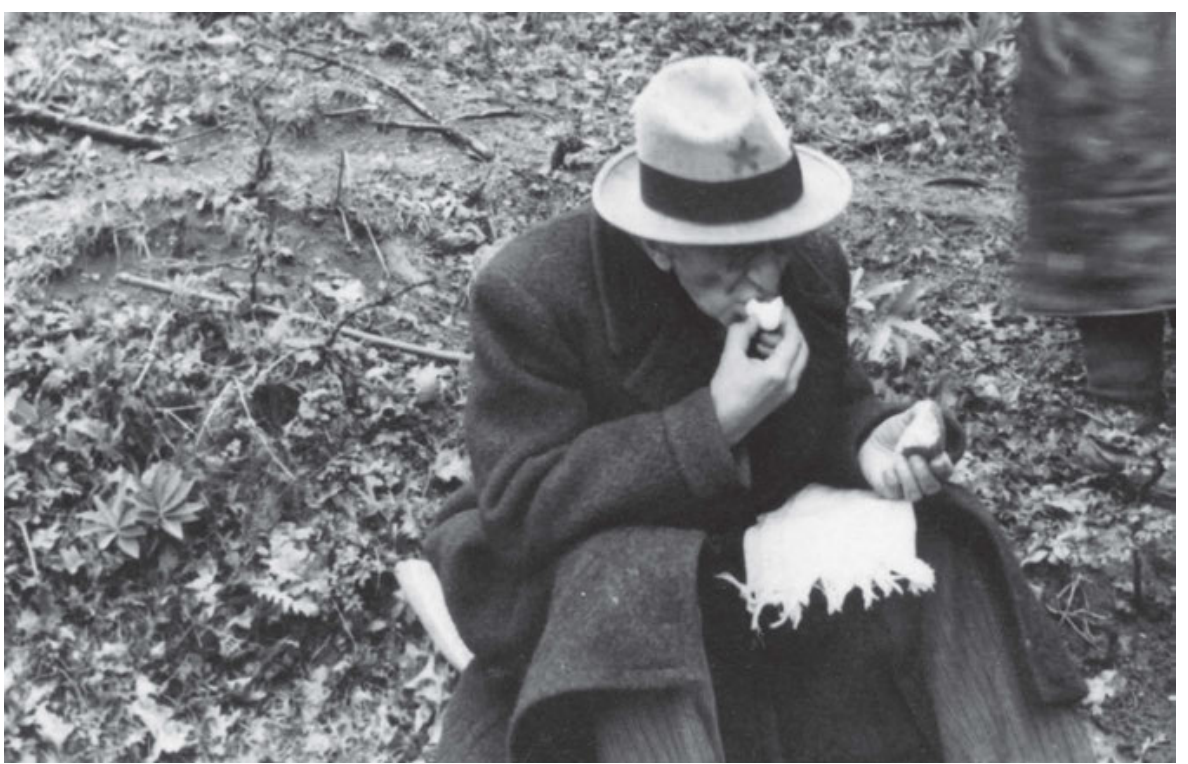

The poet Vladimir Nazor eating an apple. Photo: Mladen Iveković. Croatian History Museum, HPM/ MRNH-A-6337/135. 


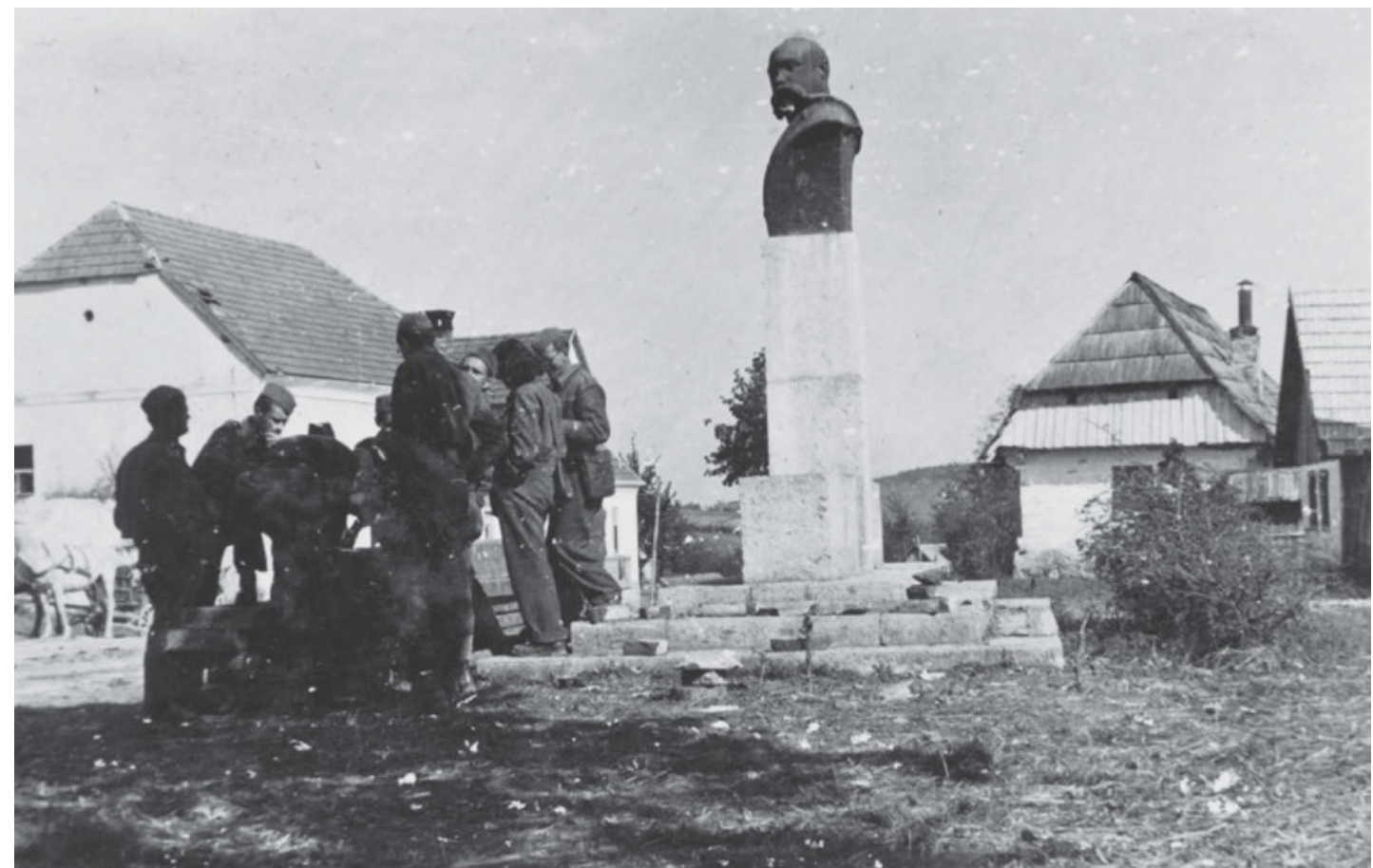

Partisans gathered beneath a statue of Eugen Kvaternik, Rakovica, summer 1944. Photo: Photography unit of ZAVNOH. Croatian History Museum, HPM/MRNH-A-2601-f129-7.

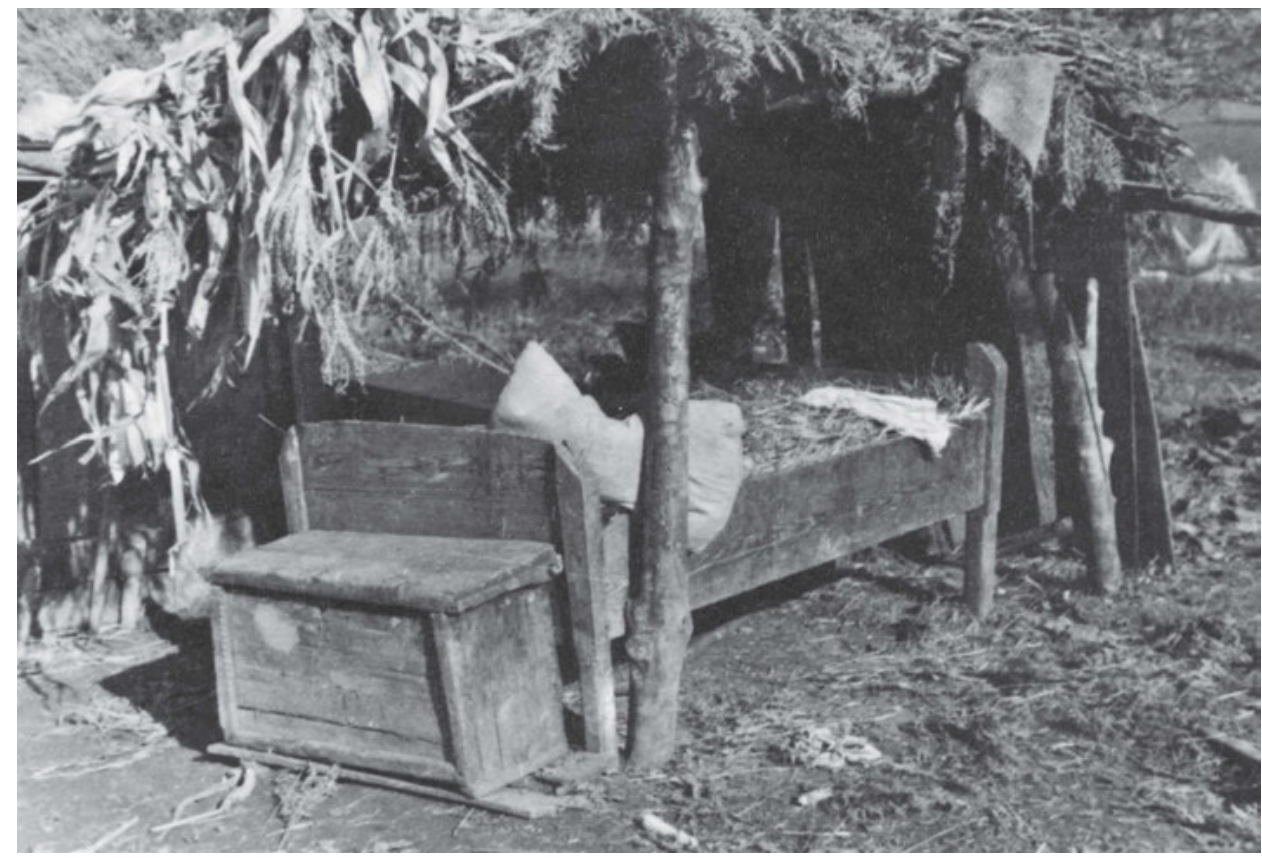

Makeshift dwelling at Kordun, 1944. Photo: Photography unit of ZAVNOH. Croatian History Museum, HPM/MRNH-2602 f88-34a. 


\section{IZLOŽBA UMJETNIKA PARTIZANA}

\section{A N K E T A}

U ciljursto uzze sutadnje izmedju umjetnika i sirokih narodnih slojeva, molimo vas, da ocgovorite na siljedeca pitanja:

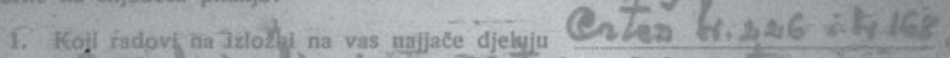
Lovoly hahensis va'strowe moupatoral iny-

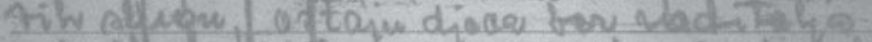

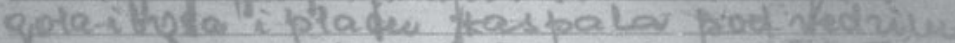

2. 798 zasto we nome iffar je uavod

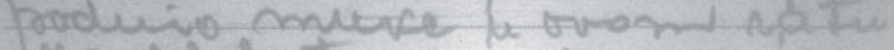

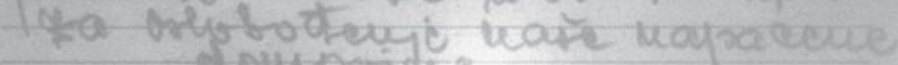

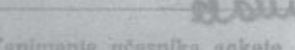

then

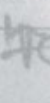

Visitor survey feedback card. Croatian State Archives, ZAVNOH Archives.

ZEMALJSKO ANTIFAŠISTIČKO VIJECEE

$36 h$ NARODNOG OSLOBOĐENJA HRVATSKE

Predsiednistvo br. 373

Glavnom Etabu Frvatske

7) 28 druge Juru - J.K. Vorozain.

Noli se drugerski neslov, de pošalje radiogrem:

+ Hod mojih u Pjljeni noiezi se na tavanu u jednoj kistri

filmski speret u limenoj kutiji. Toj eparet odmoh uputite

po kuriru ze Propegendni odjel ZaVivol-a.

$$
\text { Püstek Wertin }
$$

Smrt fasizmu - Sloboda nerodut

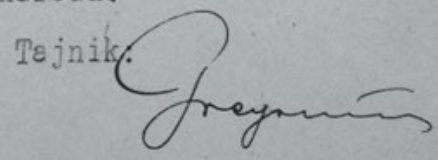

Dispatch informing the General Staff of Croatia of the discovery of a camera in an attic and the order to send it directly to the ZAVNOH's Propaganda Department. Croatian State Archives, ZAVNOH Archives. 


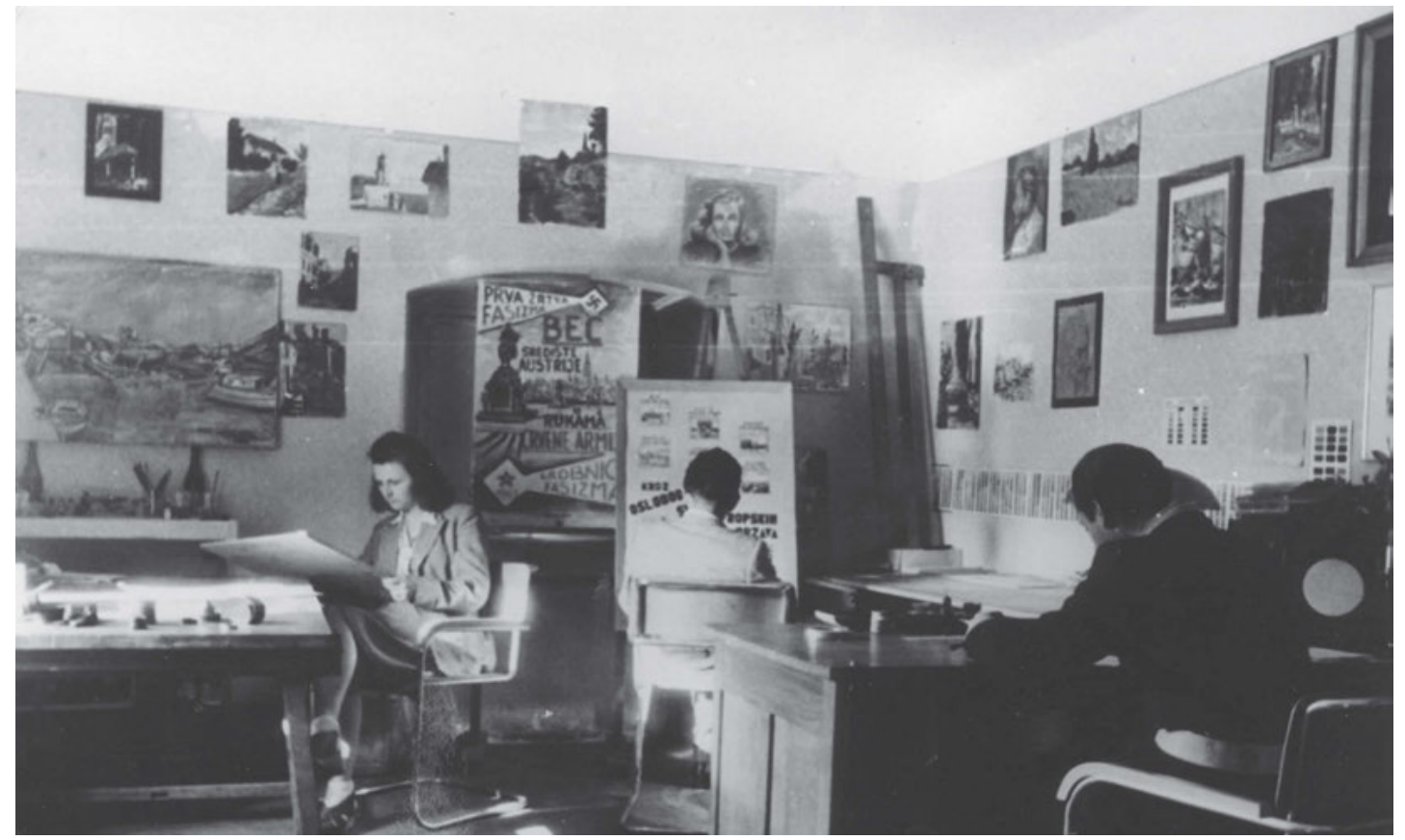

The ZAVNOH's picture archive and news desk, Dubrovnik, 1945. Photo: Nikola Rubčić. Croatian History Museum HPM/MRNH-F-8259.

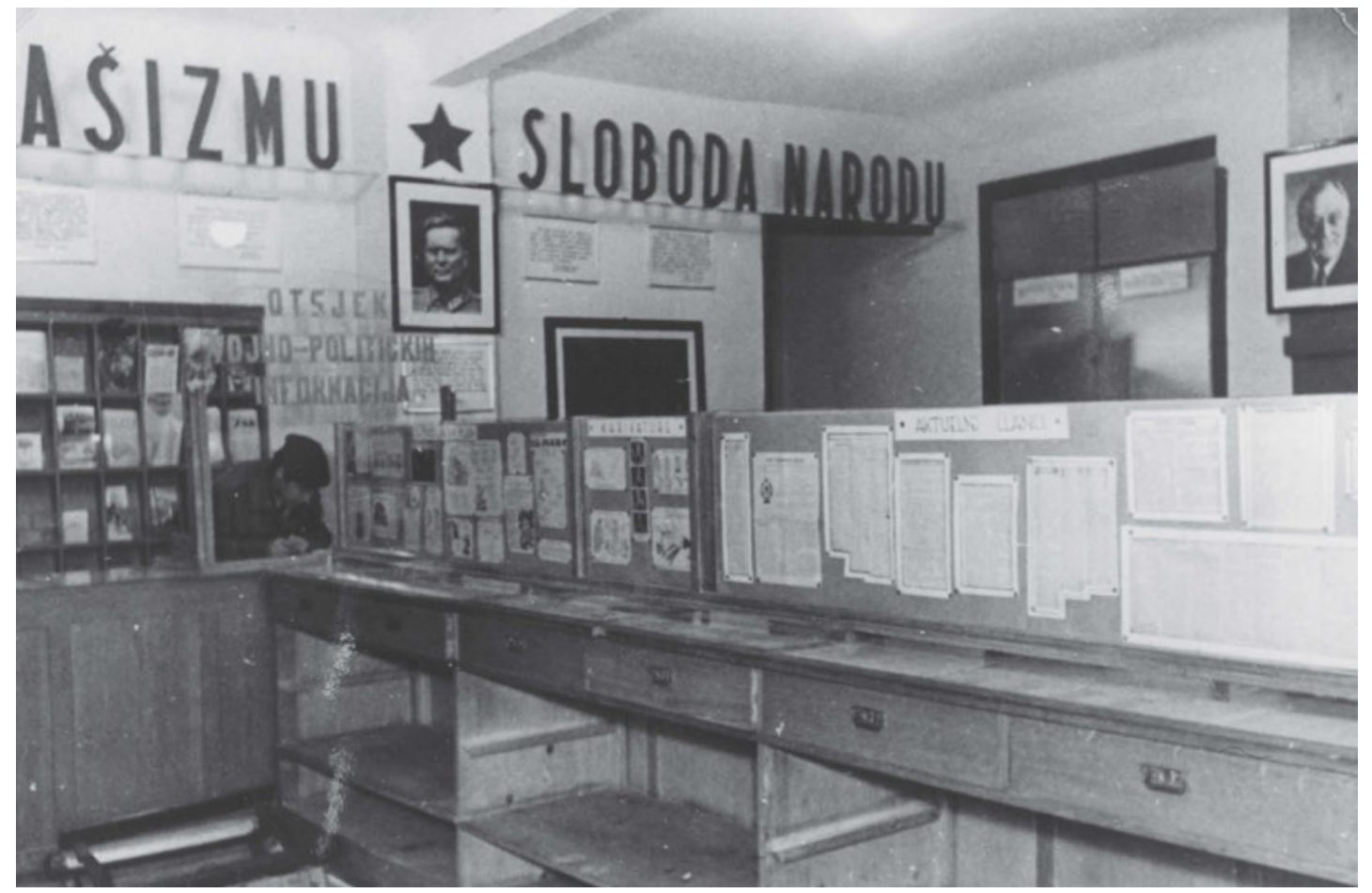

Information Office Exhibition, Dubrovnik, 1945. Photo: Nikola Rupčić. Croatian History Museum, HPM/MRNH-8247. 


\section{Franjo Mosinger's Photo Diary}

After the war, many photographs were preserved in photo albums, such as Nikola Rubčić's Rad odjela informacija u Dubrovniku (Work of the Dubrovnik Information Department), ${ }^{48}$ while the Zagreb photographer and Partisan Franjo Mosinger made a personal photo diary combining photography and text. This is a unique and distressing eye-witness account of his time in the Partisans, which leads us through his Partisan journey and work:
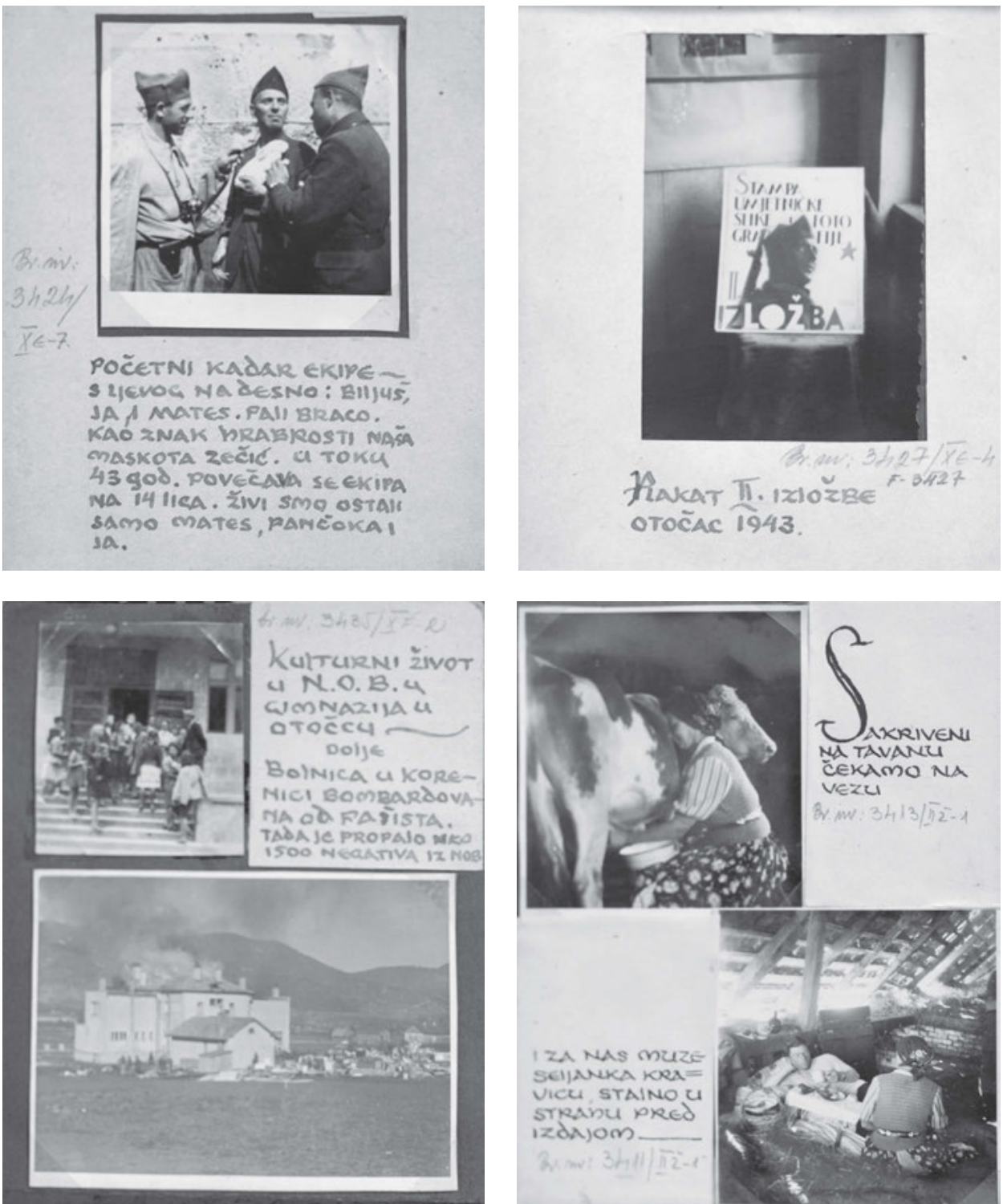

Excerpts from Franjo Mosinger's diary. Croatian History Museum. 
In early spring in the fateful year of 1943 , comrade Jovica Trzun led me to the Partisans. [...] From the village of Borčec outside Stenjevec, we set off beneath the Zagreb hills, passing through the village of Sesvete. We were really roughing it - I got to know the woods, its beauty and its horror. [...] At a house in Turopolje, we found a shelter on the next stretch. A villager, our loyal friend, put himself in mortal danger by helping us. [...] Hidden in the attic, we were waiting for our connection. Behind us, a village woman was milking a cow. Constantly in fear of betrayal [...]. As fate would have it, three hours after arriving in the village, an Ustashe formation showed up. It turned out their headquarters was in a neighbouring house. It was as if we were mice caught in a trap. For eight days we lived hidden in the shadows. We expected the Ustashe to enter the barn beneath us at any moment. And on the third day, they came in to requisition a cow. They didn't notice us.

From then on, the village woman barely dared enter the barn. They were all scared to death. We couldn't stay forever. [...] Day eight. [...] We dressed as villagers and went to the village wood. We passed the Ustashe guards unperturbed. Through an opening in the hayloft, I took photos of this scene right before our departure. Our host family's daughter didn't understand the danger her entire family were in, and she spent the time playing, without a care in the world. [...] At night we walked on further. Child guides led us. Every five kilometres one would take over from the other. At twilight they led us to a group in the woods. Just ten kilometres outside Zagreb, the heart of 'Independent Croatia', were dozens of Partisan 'saboteurs'.

The commander received us in high spirits. 'In two to three hours things'll get rough', he told us. 'You'll have your work cut out, you'll see!'

We camped out on the ground. Around us lay packets of paper, typewriters, pencils - all seized the day before from a nearby county. At 10 a.m. we got up and travelled two kilometres to a railway track, not far from Odra. The commander had put wires on the line. The train passed over them and with a loud crash, it flew off the tracks; the locomotive, the trailing tender and two carriages fell to the side. From one of the carriages, distraught faces ablaze with fear. [...] A month passed. Otočac became the liberated territory's main town. A team of war painters was established under my leadership. ${ }^{49}$

\section{Female Photographers in the Partisan Movement}

Elvira Kohn, one of the few female Partisan photographers, also worked in Croatia. She began her photography career in 1932 in the Dubrovnik studio Foto Jadran, owned by Miho Ercegović. She took commercial photographs while working for him, and her art photography was influenced by the New Objectivity. Of Jewish heritage, she was fired from the studio after Ercegović caved in to pressure from his business partner after the founding of the Independent State of Croatia. She continued to work for him in secret, however. ${ }^{50}$ Just before her death in 2003, Elvira Kohn gave her final interview to the Vienna-based Institut für jüdische Geschichte Österreichs, in which she said:

49 Text from Franjo Mosinger's original photo diary, which is stored in the Croatian History Museum.

50 Lea Šiljak, 'Elvira Kohn', in: centropa, URL: http://www.centropa.org/biography/elvira-kohn\#During\%20the\%20War (accessed 30

May 2021). 
Besides wearing a badge, we were forbidden from working in the state and public services and were deprived of our freedom of movement. We could go to the beach or market only up to a certain time of day; a curfew was imposed on us. In Dubrovnik the state authorities were in Croatian, that is, Ustashe hands but the military authorities were in Italian hands. It was lucky for us that the Italians were in power. The Germans, in collaboration with the Ustashe, attempted to put us in their concentration camps, but the Italians made it clear to them that they were in power in Dubrovnik and that they had the right to do with us as they wished. [...] They took us to a large Italian passenger ship and many Dubrovnik residents came to see us, including my boss, Miho Ercegović. When I saw him, I walked towards him and returned the camera. But he said: 'No, you keep it, and whatever happens will be caught on film.' We were first taken to Hotel Vrek in Gruž, a few kilometres from Dubrovnik. We stayed there for a couple of months, and in early January 1943 we were taken to Kupari. There were around 1,200 Jews. ${ }^{51}$

In May, the Jews at Kupari were transferred to the concentration camp on the island of Rab, which was dissolved after Italy's surrender. After Elvira Kohn's liberation, she joined the Partisans with her Leica camera, which she managed to keep with her during her stay in the concentration camp. The Partisans were surprised to see a female photographer, yet they nevertheless suggested she join ZAVNOH's war photography unit, and tasked her with photographing all events. Kohn said the following in relation to this:

I was the only woman photojournalist in the ZAVNOH. There were two other photojournalists men - who were also sometimes called up for other duties, called up for other jobs, so sometimes I was the only ZAVNOH photographer. After Supreme Command formed its own department for public relations, I started working for them and stayed there until the war ended. [...] We arrived in Zagreb on 9 May 1945 at around 5 p.m. We crossed Old Sava Bridge and arrived at the main square. The welcome was incredible. People were out on the streets all over Zagreb; they waited for us to pass, they clapped, they waved flags. The atmosphere was glorious, full of emotion, people were delighted and thrilled. Everyone knew that the war had ended, that the Ustashe and Germans had left the city, that Zagreb was liberated. After the celebrations on the main square, our group, Partisans who had been together in the war departed for Zvonimirova St., just recently home to Pavelićs headquarters. We decided to spend the night in Pavelićs headquarters and sleep there as an act of victory over the Ustashe. We were warned not to touch anything, as there was a risk that the Ustashe might have laid bombs and munitions here. We could still smell the smoke in the courtyard at the headquarters; the Ustashe must have burnt documents and papers the day before they were driven out. On my first night in Zagreb, I slept on a table in Pavelić's headquarters, in a military overcoat and with a pistol beneath me. ${ }^{52}$ 
In Serbia another female photographer also worked as part of the Partisan movement Slavka Abramović. She learnt the craft immediately before the Second World War. Just before the war started, Hungarian fascists interned her and her family in a concentration camp in the town of Senta where they lived, and she remained there for the following three months. After her release from the concentration camp, she departed for Belgrade and Valjevo. In 1944 she joined the First Montenegrin Battalion of the First Proletarian Brigade, along with her sister, Zora. She was then transferred to the brigade's cultural and propaganda section, where she worked as a photographer until September $1945 .{ }^{53}$

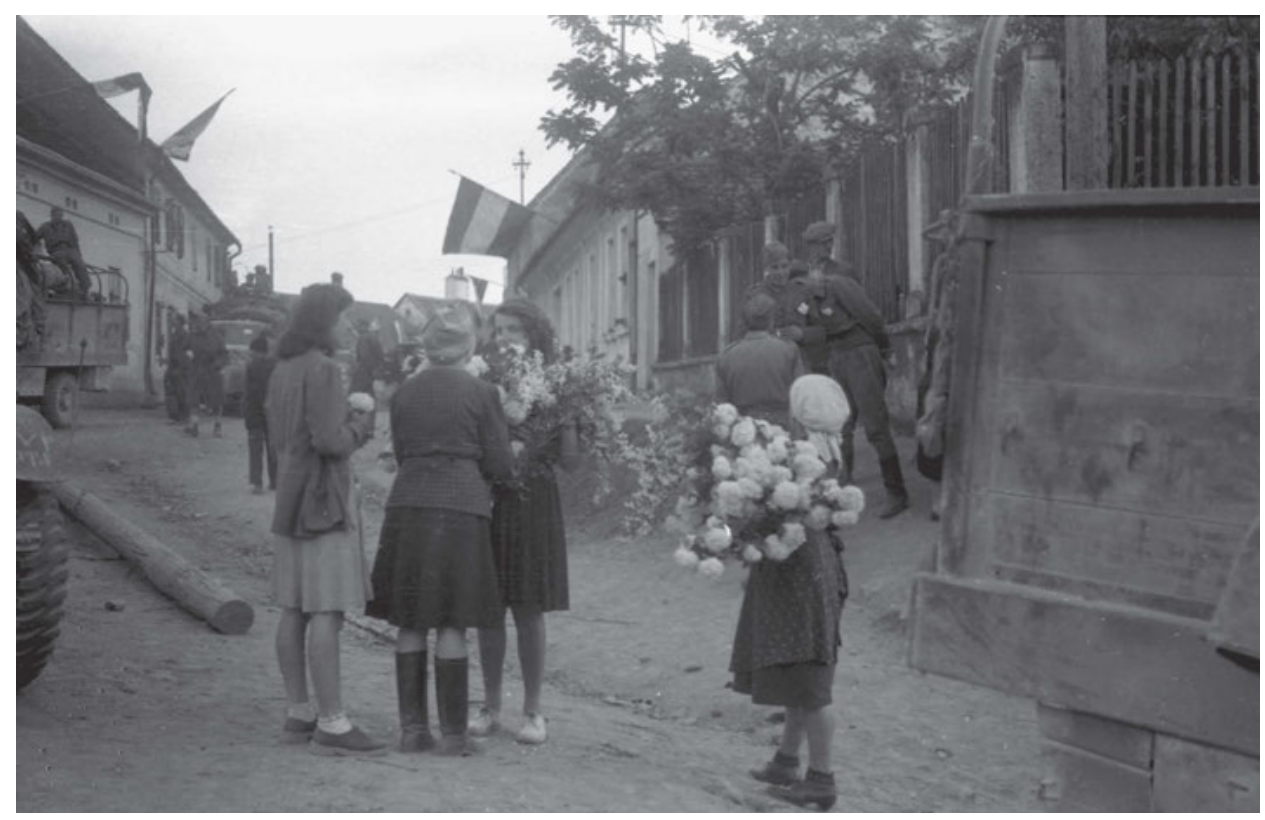

Karlovac, Croatia, after the liberation, May 1945. Photo: Elvira Kohn. Croatian History Museum, HPM/ MRNH-11474/18a.

\section{Gattin and Bernstein: A Dalmatian Photographer and an American Journalist}

In Dalmatia the Agitprop District People's Liberation Committee for Dalmatia had a photography section that was founded and led by Živko Gattin, together with the former war reporters Slavko Zalar, Jure Ruljančić and Anđelko Batinić. ${ }^{54}$ Gattin was the only Partisan photographer in Croatia who managed to shoot film in colour. After the liberation of Split on 5 November 1944, the Dalmatian photography unit set up an exhibition in the Eden cinema in Split. The exhibition traced the development of the People's Liberation Struggle, enemy war crimes, the liberation of Split, and life in the liberated city. ${ }^{55}$ The exhibition was

53 Milorad Čukić and Špiro Lagator, Partizanke Prve proleterske, Belgrade 1978, p. 161.

54 Nataša Mataušić, Koncentracioni logor Jasenovac, Zagreb 2008, p. 46.

55 Arhiv VII, NOB Archives, CS K16, reg. br. 34/1. 
opened by Cvito Fisković (the curator at the Archaeological Museum mentioned earlier), who was then head of the education department at the District People's Liberation Committee. In his opening comments, he said:

Here you will see the occupier's crimes, the execution of our children, our burnt-out villages, our tortured but persistent fighters. You will experience once again the anxious and great days of liberation through these photographs. They show how our people were tortured, how hard they fought [...]. And isn't it strange that right here, in this old Gabinetto di lettura [reading room], which is really a Gabinetto di delitto [crime room] the truth comes to light. Under this roof, autonomists and freaks turned into fascists, they built our gallows, making a show to Europe of spreading culture among barbarians. ${ }^{56}$

In Gattin's records, which I received from his family while researching this topic, he writes that his love for photography stemmed from his father, Ivan, a seagoing captain, representative of the American company Standard Oil and leader of the photography section in the Croatian hiking society Mosor. As a young man, Gattin had closely read the photography magazines of the time, following his idols such as Tošo Dabac, Milan Pavić, Franjo Fuis, Žorž Skrigin and Mladen Grčević. From them he learnt photographic techniques and methods for enlarging film. In his records, he wrote:

To this day I remember the magazine's [Foto revija's] methods for the fine-grained and soft development of film, using brilliant negatives for great enlargements: metol $6 \mathrm{~g}$, sodium sulphite $150 \mathrm{~g}$, borax $6 \mathrm{~g}$, distilled water $1 \mathrm{l}$; developing the film at precisely $20^{\circ} \mathrm{C}$ took 6 minutes. I used that excellent solution extensively throughout my life whenever developing black-and-white film [...]. When, at the end of summer 1942, I left for the Partisans, I took my Plaubel Makina with me and a supply of Agfa Isopan ISS film. At first I photographed the Partisan camp in Moseć, our hosts in Milešina below Svilaja, the Tokićs and Miletićs and their families, and the units of the emerging Third Dalmatian Brigade..$^{57}$

Gattin's father's film lab, located in the attic of their family home, became the first Partisan lab in Klis Kosa (Solin) near the Croatian city of Split. Immediately after the Italian occupation, Gattin joined the League of Communist Youth of Yugoslavia, and then chose to join the Partisans upon coming of age:

Up until then we had written slogans around Split, distributed political literature, helped the movement in the forests. That day, after our main meal, a person came to my house and whistled in front of it. We lived in Kukuljevićeva St., which is now Tršćanska St. I got up and left the table, didn't say anything to anyone at home and set off to join the Partisans, walking a safe distance of around 50 metres behind the person who had given the signal. When we arrived in Stinice, a guy from Vranjic slowly rowed over to meet us. He also gave me some tuna, as if we

56 Antifašistički Split, ratna kronika 1941.-1945: Listopad 1944. -svibanj 1945. Od oslobođenja grada do kraja rata. Odricanja i muke okrunjeni pobjedom, URL: http://www.ratnakronikasplita.com/kronika/1944-2 (accessed 30 May 2021).

57 Živko Gattin's records, provided with the kind permission of Ingrid Gattin Pogutz. 
were going on a fishing trip, and we rowed along shore to a place called Barbarinac. There was a third person waiting for me there; we passed through a vineyard and headed uphill along the old Klis road. Two milkmaids from Solin were waiting for me among some pine trees and they took me to Blaca on the slopes of Mali Kozjak. [...] When we arrived in Muć, I joined the Mosećki Detachment, whose commander was Duje Bašić from Solin. At that time Mirko Marasović, who was also a member of the Provincial Committee, said he was looking for someone to teach the detachment how to operate the mimeograph [a stencil duplicator] to print pamphlets. We then started printing Naš glasnik, whose main editor was the journalist Eli Finci, a Jew from Sarajevo. They suggested I get involved, but I wanted a gun. Marasović said to me: 'Printing pamphlets and newspapers is worth the same as four guns!' I took the Plaubel Makina with me and immediately started shooting photos, although there weren't any opportunities to develop them yet. I soon joined the agitprop group of the Provincial Committee for Dalmatia, which the Germans drove out of Livno. They were in Mosor, in the field, below Gornje Sitno. It was then decided that we would make a newspaper, and we called it Slobodna Dalmacija [Liberated Dalmatia], because it was founded on free territory. ${ }^{58}$

This kind of eye-witness account is extremely important, as most of the photographers and witnesses have since passed away, leaving few records about the context in which the photographs were taken. In a conversation for Slobodna Dalmacija, Živko Gattin revealed how he got fellow photographers Jure Ruljančić and Slavko Zalar to join him:

I requested that Maksimilijan Baće, leader of the staff, have him [Slavko Zalar], seconded to us but he didn't want to come. We argued, almost got into a fight, but then he relented. He was made number two in command. The next was Jure Ruljančić who had a well-known photo studio in Marulićeva St. He joined in Split when Italy fell. They kept him on at Slobodna Dalmacija as a typesetter. I almost didn't manage to get him either. It was just us six till the end of the war. One of them was the student Hrvoje Vidović from the Faculty of Electrical Engineering in Zagreb. While the photojournalists were embedded with the troops on the ground, someone had to look after the picture archive. It wasn't like today - the enemy could have launched an attack by parachute or ship at any time, wiping out everything, which is what happened with the picture archive of the Supreme Command in Drvar when the Germans attacked. [...] The first issue of Slobodna Dalmacija featuring our photographs was published while we were on Vis, and the copies were made on a printing machine that Jure Kaštelan and I brought from the scrubland of Blaca on Brač. The zincographs - made by transferring images to a photogravure plate of zinc or copper - were produced in the liberated Italian city of Bari. The plates with the photographs would be made there and sent back to us. [...] Under the Italians, the punishment for spreading and reading anti-fascist propaganda was prison; under the Germans, it was execution by firing squad. Yet despite this, people read and carried such propaganda far and wide. ${ }^{59}$

The photographers of Slobodna Dalmacija shot images of liberated territory in Livno, Split and on the islands of Čiovo, Hvar and Vis, where exhibitions were organised and news-

58 Damir Šarac, 'Dr Živko Gattin: Za čitanje 'Slobodne' se strijeljalo!', in: Slobodna Dalmacija, URL: https://slobodnadalmacija.hr/ kultura/dr-zivko-gatin-za-citanje-slobodne-se-strijeljalo-204129 (accessed 30 May 2012).

59 Ibid. 
papers produced. On Vis, in February of 1944, members of the photography unit also put together their first exhibition entitled Narod Dalmacije u borbi za oslobođenje (The People of Dalmatia in the Struggle for Liberation). ${ }^{60}$ Afterwards, the exhibition moved to a local school on Lastovo, and then on to Drvar for the Second Congress of the United Alliance of Anti-Fascist Youth of Yugoslavia, held on 2 May 1944. According to Gattin's account, he and Slavko Zalar carried the exhibition in two bags, across Ravni kotari in northern Dalmatia to Drvar, where it was set up in one of the sheds of a timber yard named Šipad.

The exhibition then moved on to the liberated town of Hvar to coincide with the Congress of People's Liberation Committees of Dalmatia being held there. The next stop was the Eden cinema in Split, then Šibenik and then on to Belgrade, where Dalmatian war photographers were also waiting, anticipating the end of the war.

Gattin's account of his journey to Drvar also sheds light on the fantastic and thrilling tale of the American journalist Walter Bernstein, whom Gattin was ordered to accompany. Besides travelling together on foot, Gattin helped Bernstein carry the bag containing the exhibition contents. His story is especially interesting as, while serving as a lieutenant in the US Army, Bernstein managed to infiltrate the liberated territory without his superiors' knowledge and was the first Western journalist to interview Josip Broz Tito. The interview was later published in the magazine Yank, The Army Weekly. ${ }^{61}$

In 1941, as a young man aged twenty-two, Bernstein enlisted in the American army where he worked as a correspondent in the Middle East. During this time, indeed until 1944, the

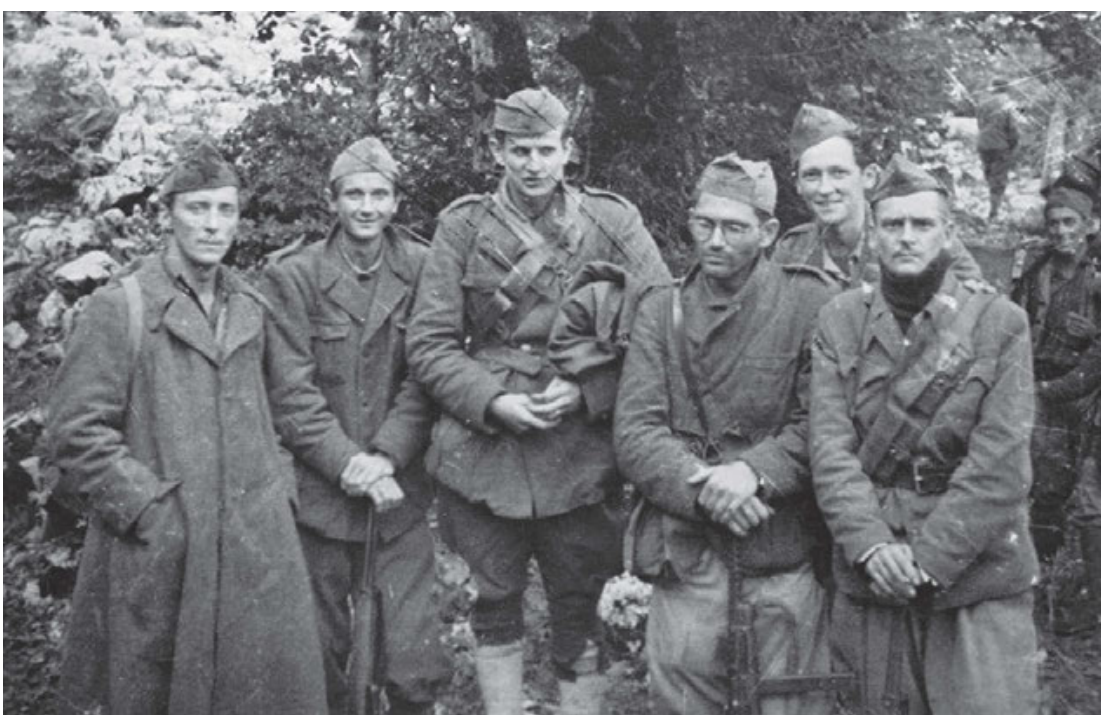

The war photography team of Slobodna Dalmacija: Ruljančić (left), Zalar, Kohn, Batinić, Gattin and Klišmanič (right), Vis 1944. Photo: Slobodna Dalmacija. Private collection of Ingrid Gattin Pogutz.

60 Hlevnjak/Ivanuš 2008 (see note 18), p. 113; Walter Bernstein, 'Interview with Tito of Yugoslavia', in: Yank, The Army Weekly, 16 June 1944, New York, pp. 8-9.

61 Bernstein 1944 (see note 60). 
Partisan movement remained subject to Allied, particularly British, censorship, as the UK government continued its support of King Peter II, the last king of the Yugoslav government in British exile and a member of the Karađorđević dynasty. Although the People's Liberation Army did receive some Allied assistance in the form of weapons and other equipment, the Allied news blackout was pervasive. Breaking it was key, as this was the prerequisite for the Partisan movement being recognised as the only legitimate anti-fascist movement in Yugoslavia. In turn, this was a precondition for future international recognition of the new state after the war.
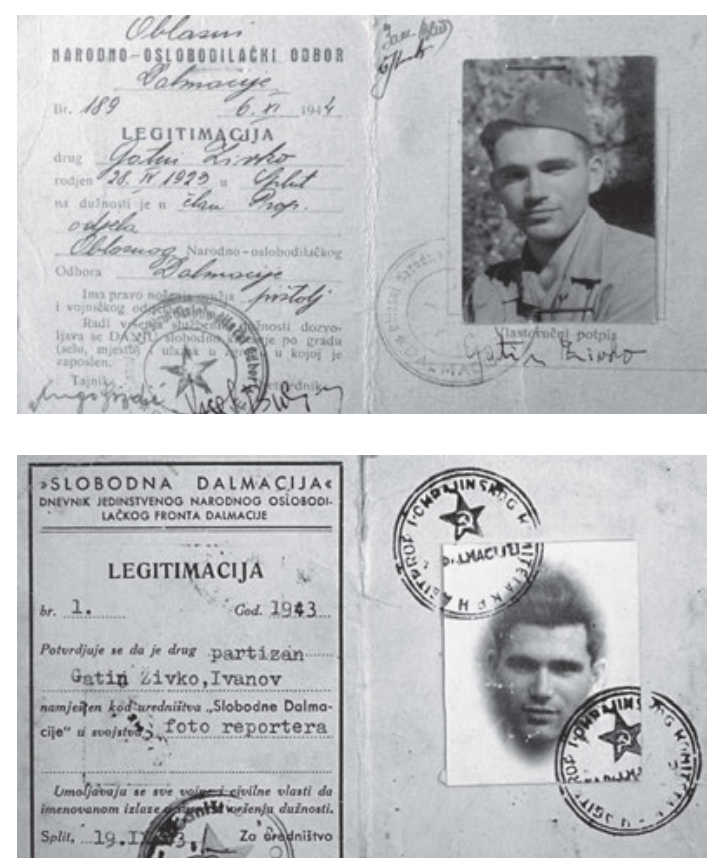

Živko Gattin's personal documents. Private collection of Ingrid Gattin Pogutz.

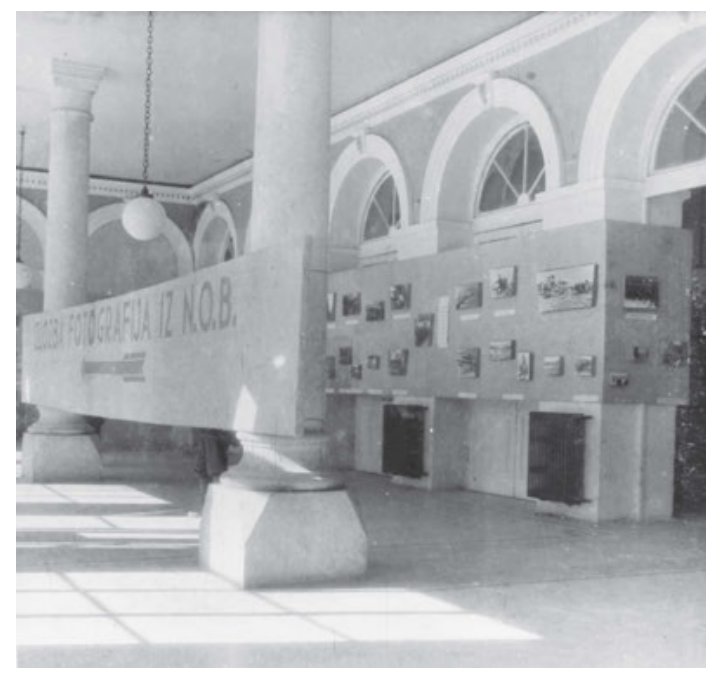

During the conference, an exhibition of photographs of the People's Liberation Struggle went on show. Installation view with banner bearing the slogan: 'Exhibition of photographs recording the People's Liberation Struggle', Hvar, 12-13 October 1944. Photo: Miloš Žanko. Croatian History Museum, HPM/MRNH-F-43.

Sadly, Walter Bernstein died in January 2021. In his later years, he lived in New York and in 2017 he agreed to a conversation for this book. During the war, he received an invitation to visit Yugoslavia from Vladimir Dedijer and Milentije Popović, whom he met in Cairo. Shortly afterwards, he travelled to Bari in Italy, a vital Allied navy base at the time, on his own initiative. His goal was to set off for Yugoslavia, which was still under Axis occupation but also under an Allied news blackout.

I came to the special Balkan section of the US Army, which supplied weapons to the Partisans. I went to speak with the American officer and told him that I wanted to travel to Yugoslavia. He laughed and said no one had been allowed to travel to the Partisans. He said: 'Stay here and 

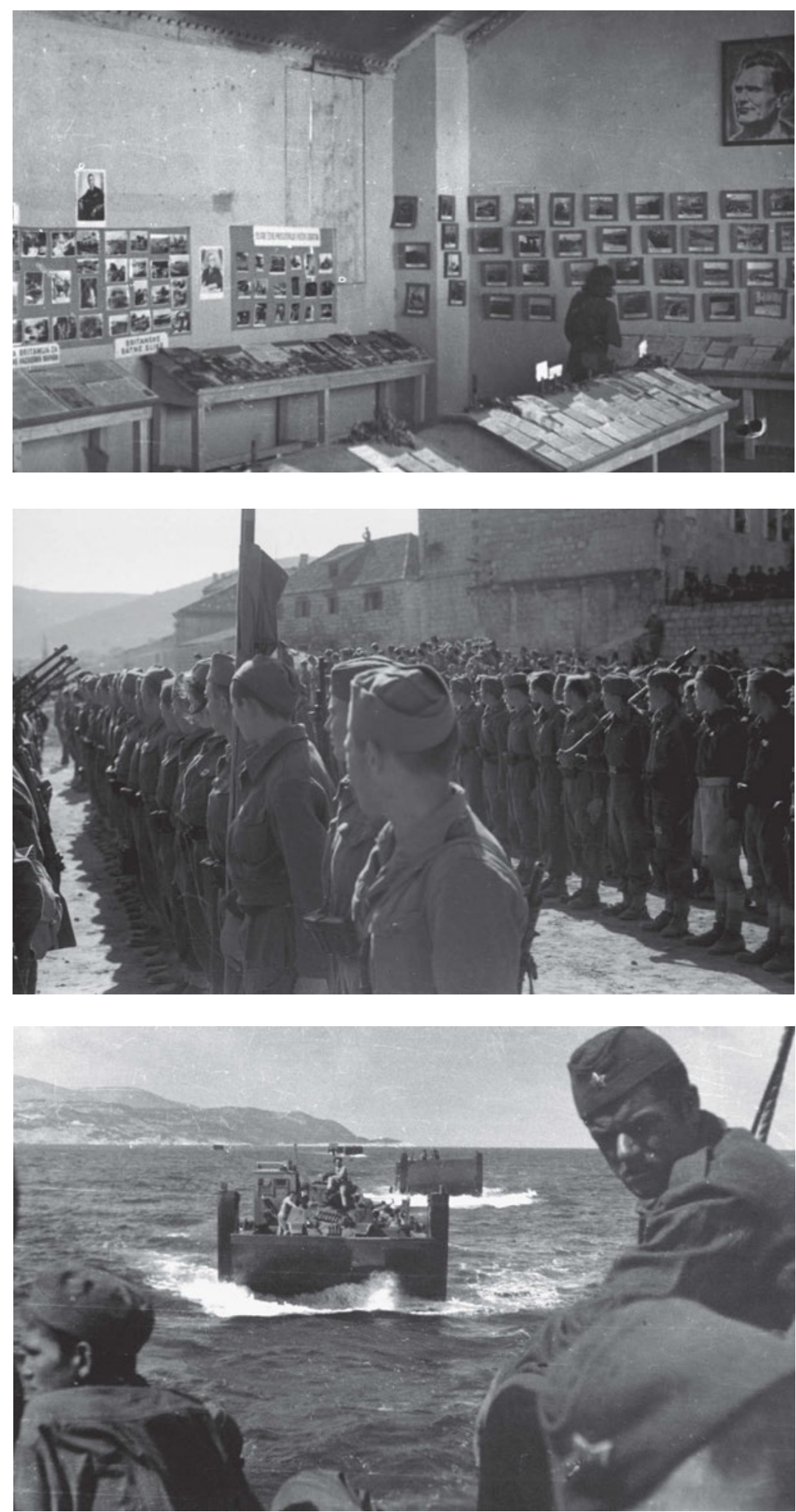

View of exhibition held at the Second Congress of the United Alliance of Anti-Fascist Youth of Yugoslavia, Drvar, May 1944. Photo: Živko Gattin. Croatian History Museum, HPM/MRNH-A-11701/52.

Parade of First Dalmatian Brigade on the island of Vis, September 1944. Photo: Živko Gattin. Croatian History Museum, HPM/MRNH-A2602-f146-69.

Sea convey of munitions, coast of Vis, 1944. Photo: Živko Gattin. Private collection of Ingrid Gattin Pogutz. 


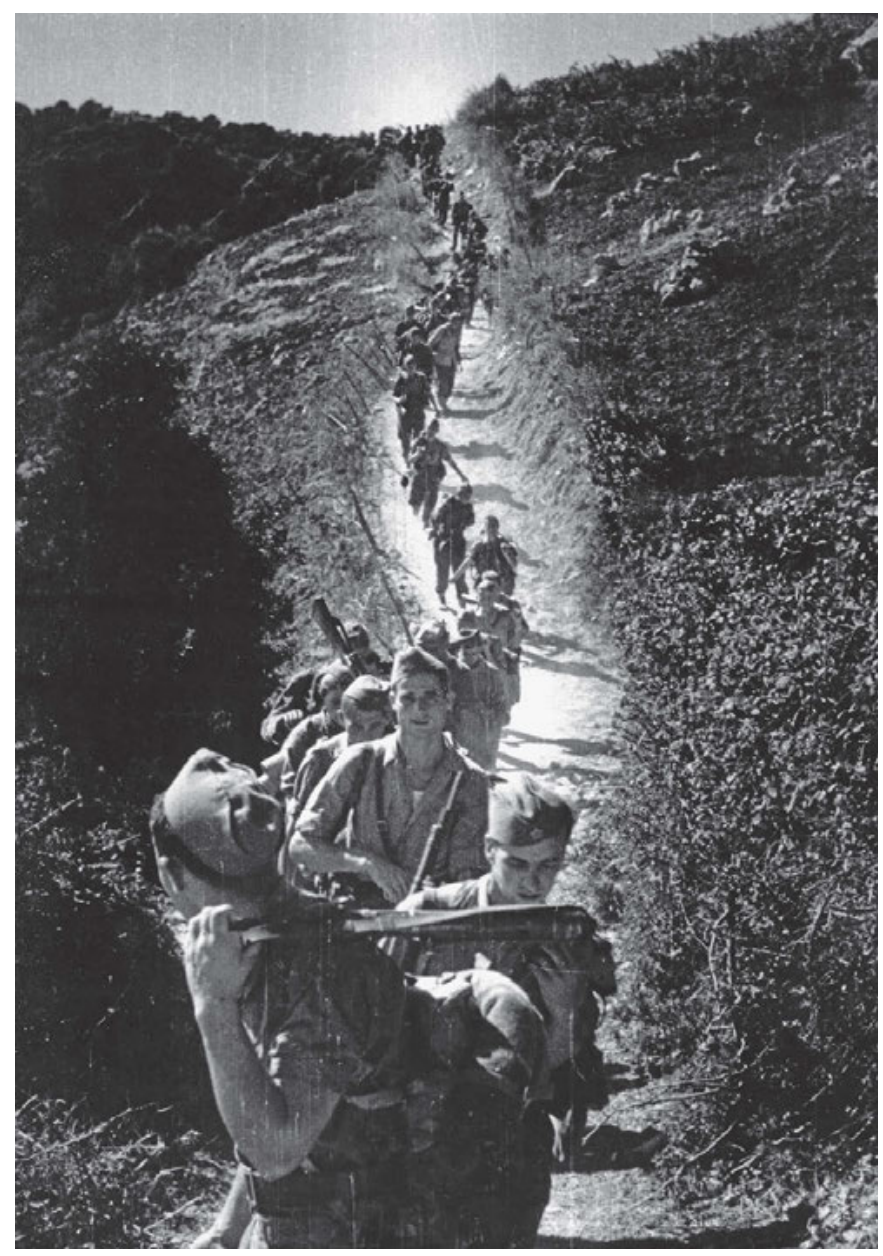

Partisans liberate Hvar, September 1944. Photo: Živko Gattin. Private collection of Ingrid Gattin Pogutz.

write articles about us.' Then I told Dedijer that I hadn't been permitted to travel to Yugoslavia, to which he replied: 'Fuck him, this is our state and if you want to come, come! We'll take you there. ${ }^{62}$

On the way to Drvar, Bernstein's bag with all items and a camera was stolen in the night. After this incident, Gattin gave him his camera and all the rolls of film that he had shot on the journey from Vis, because he deemed it important that the photographs be published in the American press. After arriving in Drvar, Bernstein also organised a first meeting with Tito:

I remember him being in a big cave, a cave that protected the house he was in. I remember him having a big dog. He welcomed me from behind a big table and I just saw him briefly the first time. I believed everything I had seen in the Partisans; it grabbed me, and I wanted to be part of it all. From today's position, I think I was very young and my questions were naive. He was really impressive, his whole being. He wasn't fat as in later years. I knew that before the war, he had 
travelled illegally by pretending to be a rich entrepreneur. I had the feeling that he was capable of anything and everything and all that he did was tremendously important to me. ${ }^{63}$

The conversation between Bernstein and Tito was conducted in English, and the interpreter was a woman called Olga. The next day was supposed to include a second meeting for the young American lieutenant, but it unfortunately did not happen.

After the first preliminary conversation with Tito, another, longer, conversation had been agreed for the following day. That evening I decided to go for a walk and came across a British officer who was really surprised to see someone in Allied uniform. He was an unimportant officer on a British mission to the Supreme Command. He sized me up and asked me who I was. I explained to him what I was doing here, and then he said that I had broken all possible commands and that I had to go with him. He took me to the British mission where Randolph Churchill, the son of Winston Churchill, could be found. He thought it was funny that they'd come across me in Drvar, but he then said that I was under arrest and that they would send me back to Bari. On the plane back, I sat with him and remember him being terribly drunk. I was disappointed and somewhat afraid. I didn't know what would happen to me and I didn't believe anyone except the Partisans. I was scared then that they wouldn't publish what I had written. I wanted to stay with the Partisans for longer and write many more articles. At the same time, I knew that the British had organised a first official visit to the Partisans, with a handful of journalists and photographers. They were meant to be the ones who would tell the official story of the Partisans. ${ }^{64}$

Bernstein left for Bari as a military prisoner. However, outside Bosanski Petrovac on 9 May 1944, a plane did in fact land with the first official team of war correspondents to arrive with Allied command's permission. The team consisted of a reporter from Time magazine, Stojan Pribićević (son of the politician Svetozar Pribićević), a photographer for Reuters named John Talbot, the British photographer Gene Fowler and an American photographer named Slade. Six days later, a dinner with Tito was organised for them ${ }^{65}$ and they are regarded to this day as the first Western press delegation to visit the Supreme Command. This is because their reports were published before Bernstein's interview in the issue of Yank released on 16 June 1944. In the interview, Bernstein wrote:

Tito's cosmopolitanism becomes more apparent the longer you are with him. He isn't a simple peasant leader, but rather a man of the world. In fact, Tito is an exceptionally sophisticated person in the best sense of the word. There are moments when he gives you the impression of being a good actor - he wears the uniform with talent. ${ }^{66}$

A few months later, Bernstein sent Gattin a package with his roll films and published several more articles in which he mentioned their journey together. ${ }^{67}$ Before the war, Bernstein had not been a member of the Communist Party, but his journey to Yugoslavia was about him fulfilling his youth ideals, contributing to the struggle and breaking through the news

\footnotetext{
63 Ibid.

64 Ibid.

65 Walter E. Roberts, Tito, Mihailović and the Allies, 1941-1945, Durham, North Carolina 1987, p. 227.

66 Bernstein 1944 (see note 60).

67 Walter Bernstein, 'Walk Through Yugoslavia' in: Yank, The Army Weekly, 28 July 1944, New York, pp. 8-9.
} 
blackout. Before Bernstein, only the Associated Press had had a conversation with Tito, in writing, through a Partisan intermediary in Bari. Allied command censored the interview, however, and only after several interventions, including by President Roosevelt himself, was the conversation published on 21 May 1944. This conversation was crucial in recognising the People's Liberation Army and key to future support from the Allies. ${ }^{68}$ The first photographs that passed through the Allied military censors were published on 6 December 1943 in Life, and they were taken by the British lieutenant Lambton Burn. ${ }^{69}$

Just a few days after the conversation between Tito and Stojan Pribićević, on 25 May 1944 Axis forces launched their Seventh Enemy Offensive and the landing operation on Drvar. In the Germans' operation codenamed Operation Rösselsprung (Knight's Leap), the Supreme Command barely escaped with their lives, and many foreign intelligence officers and Partisans died. The Allies whisked Tito off Yugoslav territory in a Russian plane to Bari. In Drvar, Pribićević and Talbot were captured, as were the other two foreign press photographers, but Pribićević was soon freed in a Partisan counter-attack. The others were liberated in the end. The Partisan photographer Vili Šimunov-Barba, the first photographer to work for Yugoslavia's official news agency, TANJUG (Telegraphic Agency of the New Yugoslavia), did not have such luck and died in an attempt to save his negatives from fire from the road linking Drvar and Oštrelj. Born in Ogulin with the birth name Vilim Schwarz, he changed his name to Šimunov and joined the Partisan movement when the quisling Independent State of Croatia was established. He collaborated with the Communist Party of Yugoslavia before the war, too, and in Drvar he set about creating the Partisan press archive. He was also the first official photographer of the Supreme Command of the People's Liberation Army and the Partisan Detachments of Yugoslavia (NOV i POJ).

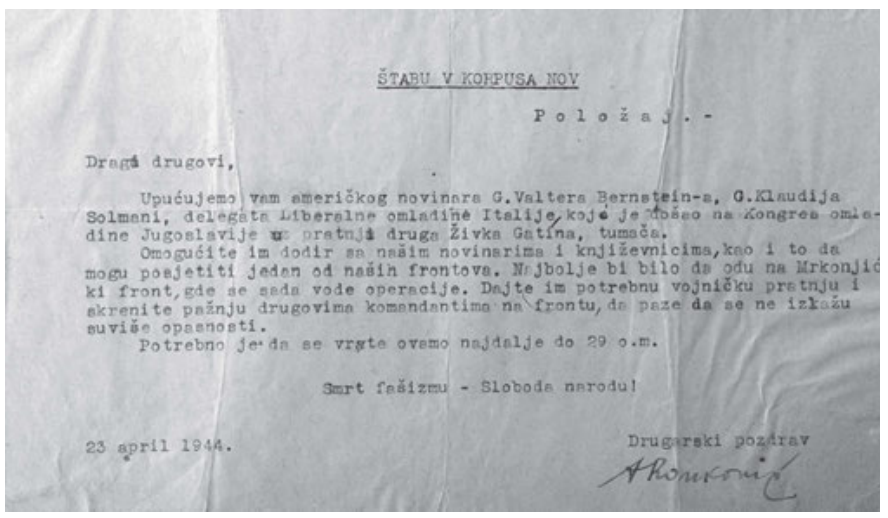

Aleksandar Ranković's order confirming that Walter Bernstein accompanied Živko Gattin. Private collection of Ingrid Gattin Pogutz.

68 Roberts 1987 (see note 65), pp. 227-228.

69 Nikolina Kurtović, Communist Stardom in the Cold War: Josip Broz Tito in Western and Yugoslav Photography, 1943-1980, doctoral thesis, Toronto: University of Toronto, 2010, p. 55. 


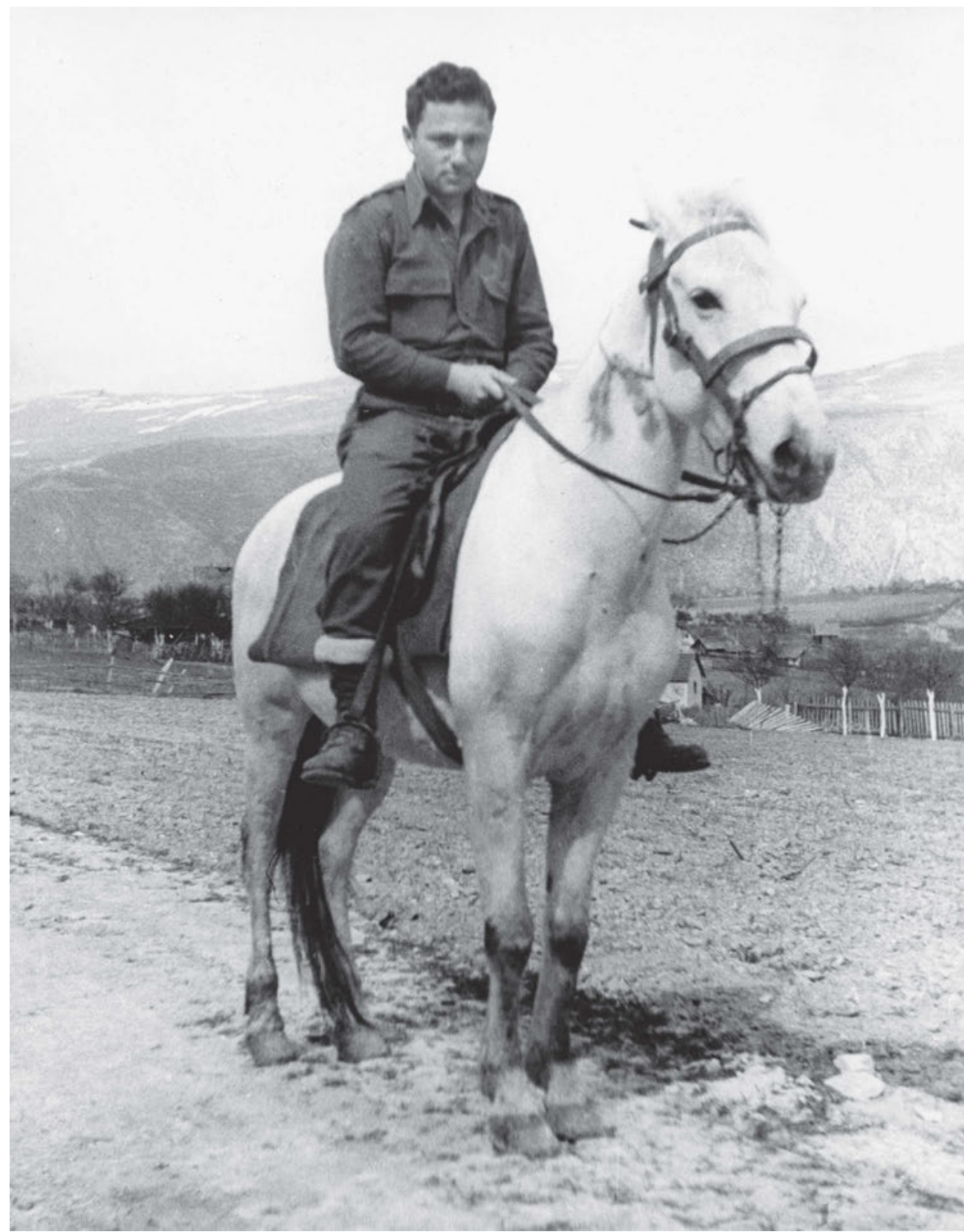

Walter Bernstein on horseback on route to Drvar. Photo: Živko Gattin. Private collection of Ingrid Gattin Pogutz. 
Dalmatia, Slavonia, Bosnia, Serbia, Slovenia ...

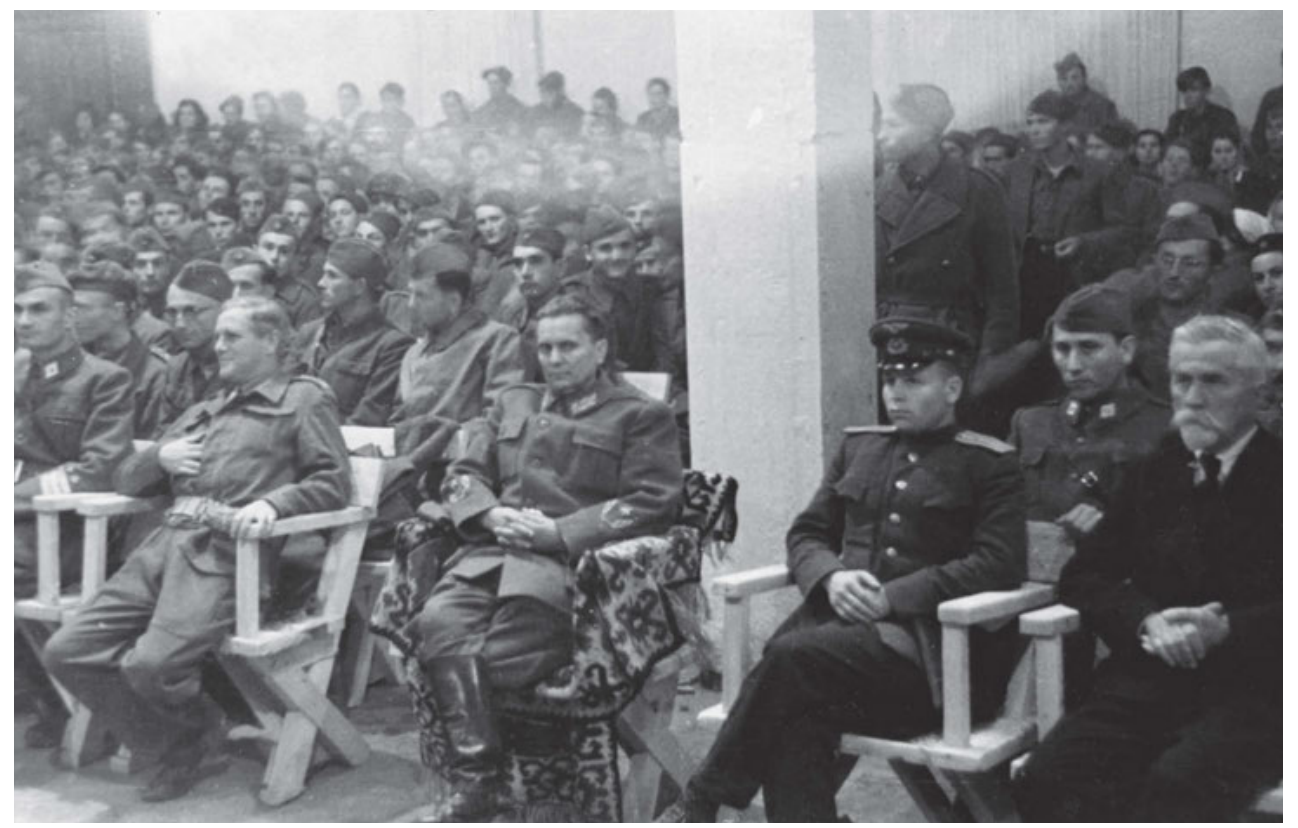

Second Congress of the United Alliance of Anti-Fascist Youth of Yugoslavia, Drvar, 1944. Randolph Churchill (left, with hand on chest) and Josip Broz Tito (centre). Photo: Živko Gattin. Private collection of Ingrid Gattin Pogutz.

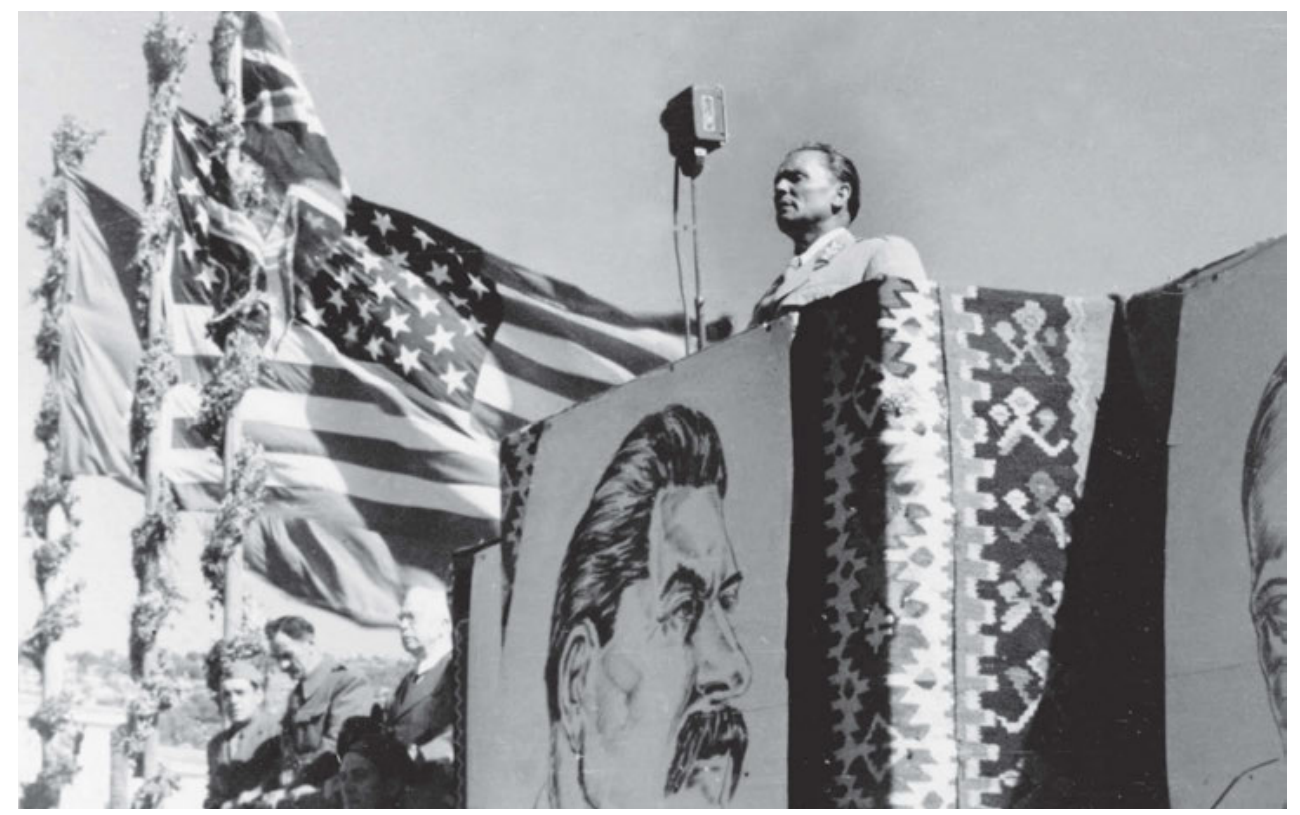

Tito's speech on Vis, 1944. Photo: Živko Gattin. Private collection of Ingrid Gattin Pogutz. 
Besides the Dalmatian photographers discussed above, Ante Roca deserves a special mention. In 1943 he joined the headquarters' support unit of the North Dalmatian Division. ${ }^{70}$ When tasked on one occasion with acquiring equipment, he fell into enemy hands and was captured by German soldiers. After interrogating him, they brought him to a prison camp in the Croatian town of Slavonski Brod. He managed to escape from there and later worked as a photographer for Vjesnik. ${ }^{71}$

A lesser-known fact to this day is that Stevan Benčić, the pre-war photographer at the daily newspaper Politika and parliamentarian in the Assembly of the Kingdom of Serbs, Croats and Slovenes, was also involved in the Partisan movement. Love brought him to Hvar, and over time he expanded his business down to Dubrovnik and Budva. He photographed tourist sights and made postcards. He was the Agfa representative for this part of Dalmatia. During the short-lived period of Ustashe rule on the island of Hvar he was imprisoned, but his family managed to have him freed by bribing local officials. He supported Božo Novak with equipment, and Novak later became an important Croatian journalist. In 1943, Stevan Benčić joined the ranks of the Partisans, where he later came across Vladislav Ribnikar, who helped him get involved in TANJUG. It was also during this time that he shot Tito's portrait, which was later used on postal stamps.72

The Zagreb small-business owner and photographer Ernest Grgić has also been overlooked in the history of Partisan photography. He was involved in the workers' movement even in the 1930s, before leaving for the Spanish Civil War as a volunteer. He collaborated with Vili Šimunov-Barba in the Partisans, and they worked together on creating the Partisan picture archive. During the war he was a radio telegrapher for the Fifth Krajina Corps, ${ }^{73}$ and he also organised telegraphy and photography courses.

One of the especially impressive collections of photographs, now in the Croatian History Museum, was amassed by the photography section of the District People's Liberation Committee of Slavonia, in which Pero Dragila, Vlado Potočjak, Mate Tačković and Milan Crnelić worked. ${ }^{74}$ This photography section even made photomontages for special occasions, such as to celebrate Serbian Orthodox Christmas. They successfully held photography exhibitions, such as the one held in Orahovica in 1944.

A mother with her children at the site of their burnt-down house in the village of Knezovljani in Banija, Central Croatia, April 1945. Photo: Ante Roca. Croatian History Museum, HPM82093-2.

Besides the photographers mentioned so far in this collection, there is one photographer unknown to this day - whose square-format photographs stand out in style and quality. After extensive research, the person behind these images is likely to be Miro Matašin, boss

\footnotetext{
70 Rhea Ivanuš, 'Ratni ciklus Ante Roce Svjetlo na pepelu i Zadar 1944', in: Ante Roca fotograf stvarnosti, Tončika Cukrov (ed.),

Zagreb 2013, p. 71.

71 Andrija Mutnjaković, 'Ante Roce', in: ibid., p. 15.

72 According to the oral account of Stevan Benčić's daughter and the Croatian historian Zorica Stipetić (1 December 2017).

73 Metod Antunac, 'Neretva i Sutjeska', in: Veze u NOB-u, Ratna sećanja 1941-1945, Radomir Petković (ed.), Belgrade 1981, p. 221.

74 Hlevnjak/Ivanuš 2008 (see note 18), p. 114.
} 


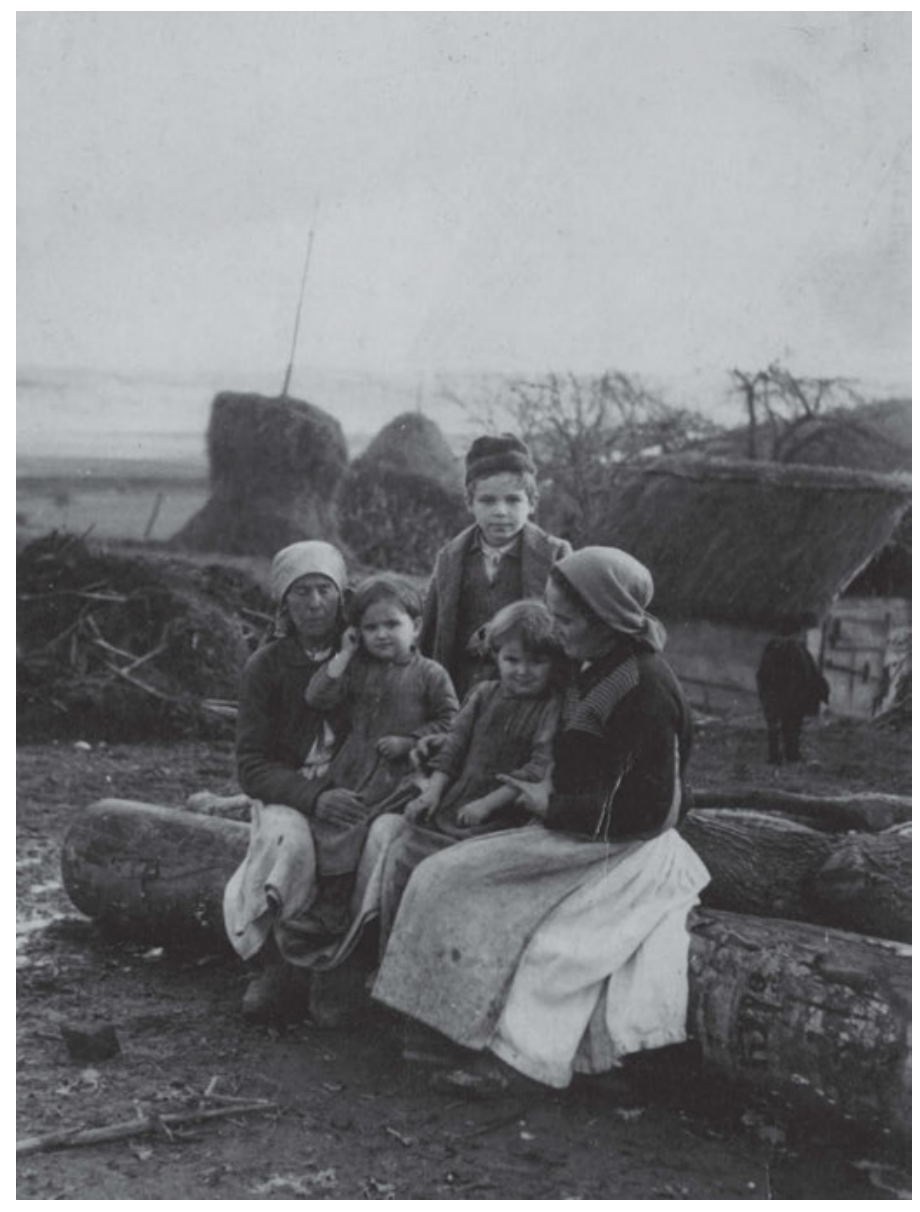

A mother with her children at the site of their burnt-down house in the village of Knezovljani in Banija, Central Croatia, April 1945. Photo: Ante Roca. Croatian History Museum, HPM-82093-2.

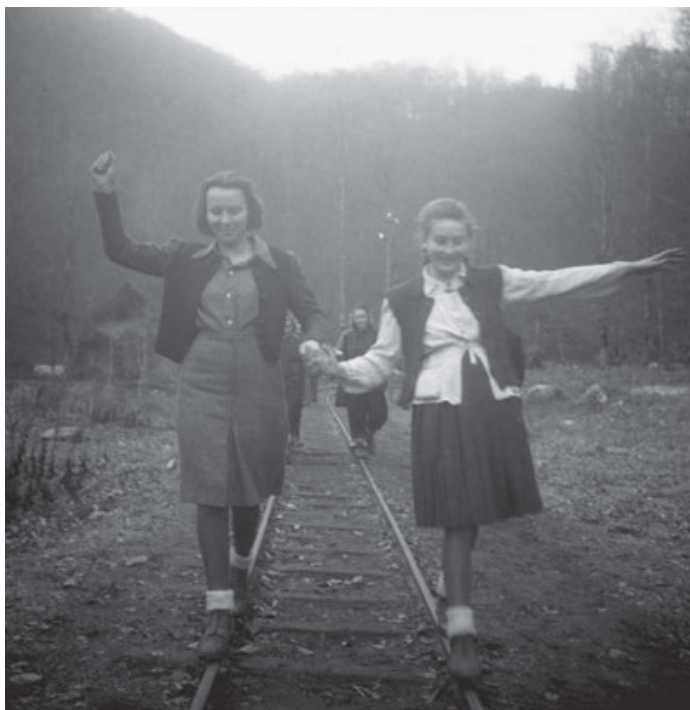

Partisan women in Slavonia, 1944. Photo: Miro Matašin. Croatian History Museum, HPM/ MRNH-A-2203/1837.

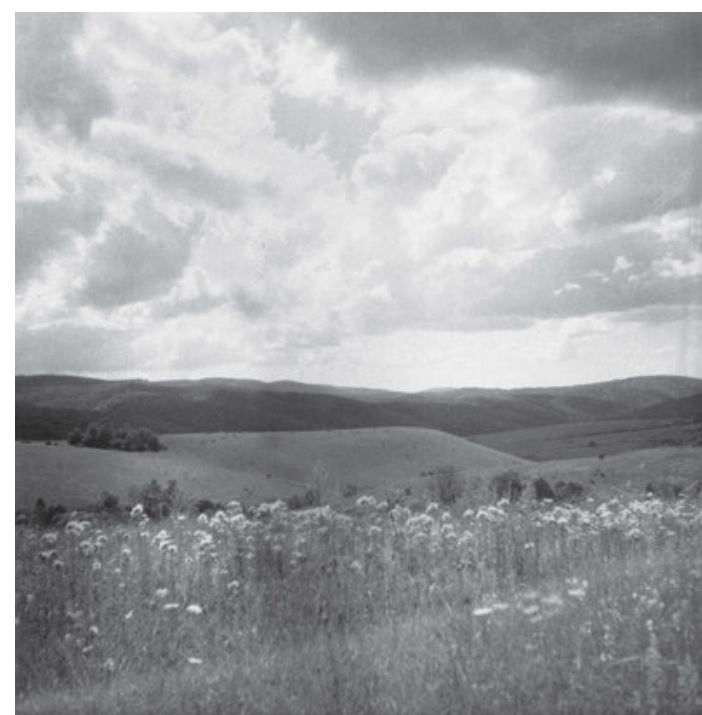

Slavonia. Photo: Miro Matašin. Croatian History Museum, HPM/MRNH-A-2203/1695. 
of the photography unit of the District People's Liberation Committee of Slavonia. The photographer is named in a caption beneath the picture dated 31 May 1944, taken in Duboka River on the mountain of Papuk. According to the caption, the image shows the surgeon Jože Koporc and the scrub nurse Meri Barvinski. ${ }^{75}$ By analysing the style, format and technical qualities, we can say that this picture is almost certainly the same camerawork as the other square-format photographs in the Croatian History Museum collection. The name stated in the caption, however, is 'Marašin'. This is most likely a mistake, however, as there is no record of a Partisan photographer with this surname. The Partisan photographer Miro Matašin was also active after the war, as the exhibition catalogue of war photography from Salon Becić in Slavonski Brod in 1981 confirms. ${ }^{76} \mathrm{~A}$ copy is held in the Petar Preradović National Library in Bjelovar, in a local-heritage collection about people from Bjelovar. The 1981 exhibition was the first time Matašin had shown most of his photographs, which tells us that this talented photographer faded into obscurity after the war.

Who, then, was Miro Matašin? He was born in the village of Uljanik, near Garešnica in Croatia, and his father was a county clerk and trader. After finishing school, just as war was breaking out, he bought his first camera and processing equipment and took up amateur photography. At the age of twenty-two, he transported his photography equipment in a farm cart, arriving in 1943 on the outskirts of Zvečevo. At that time, he used cameras like the Leica and Rolleiflex, which was also why most of his photographs were in a square, $6 \times 6 \mathrm{~cm}$ format. He set up a film lab on the outskirts of Zvečevo, and Nikola Popović and Drago Pavlić worked with him. He also became the photographer for the staff of the Fortieth Division, and later accompanied Kosta Nađ and the general staff of the Third Army in liberated countries up to the border between Slovenia and Austria. He was demobilised in 1946,

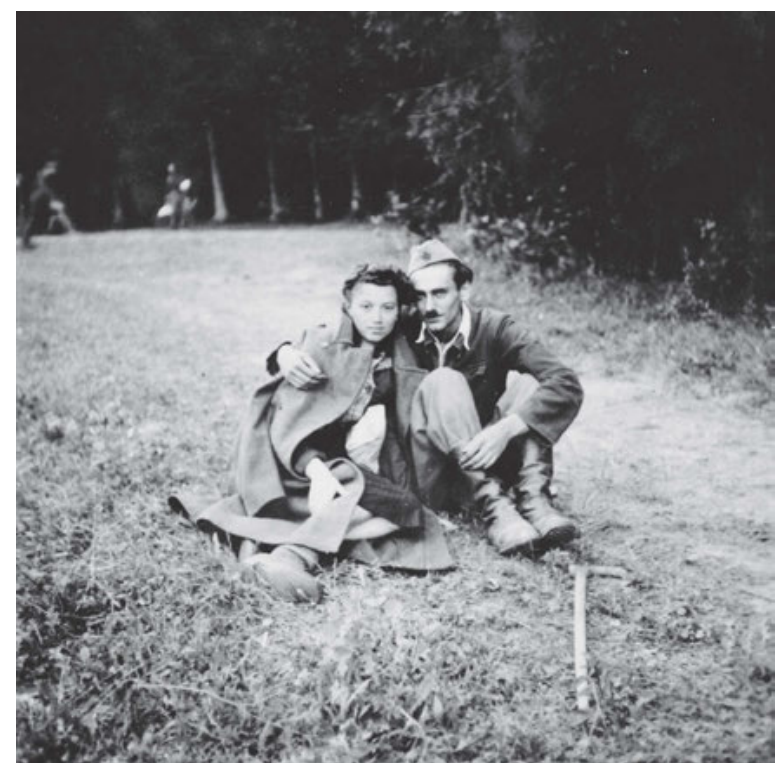

Ljutoč on Papuk mountain, convalescent home for the injured of the Sixth Corps, 1944. Photo: Miro Matašin. Croatian History Museum, HPM/ MRNH-A-2203/1718.

75 Braco Kocković, I tamo smo samo ljudi bili (tragovima partizanskih ranjenika), Zagreb 1982, p. 57.

76 Miro Matašin, Ratne fotografije: Salon Becić (exh. cat.), Slavonski Brod 1981. 


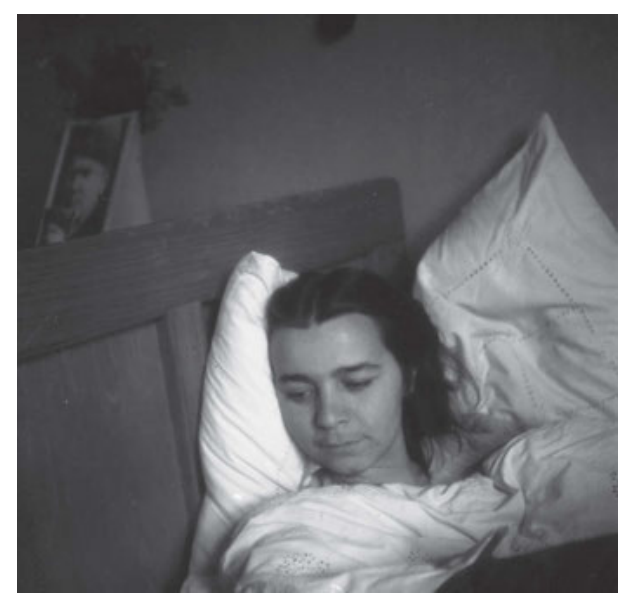

A young Partisan in hospital, Slavonia, 1944. Photo: Miro Matašin. Croatian History Museum, HPM/MRNH-A-2203/1780.

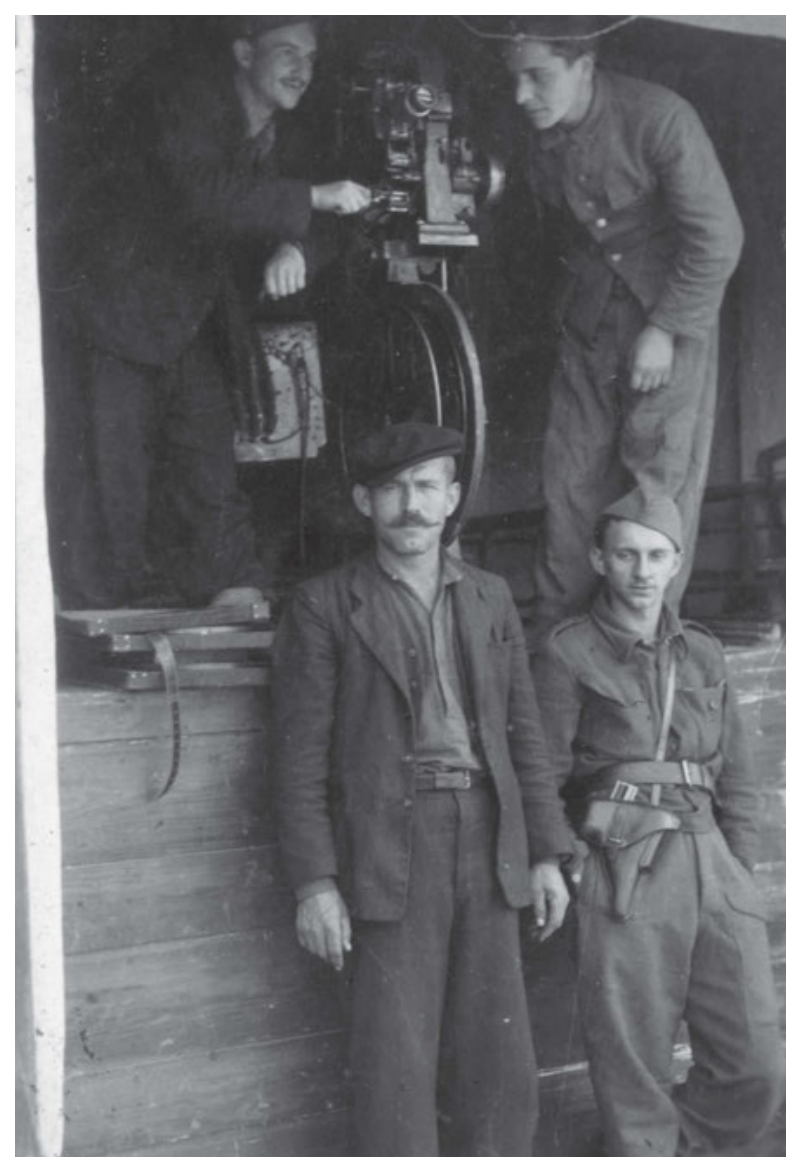

Projectionists in the first Partisan cinema team, Novo Zvečevo, Slavonia, 1943. Photo: Unknown photographer with the District People's Committee for Slavonia. Croatian History Museum, HPM/MRNH-F-4312.

and then sold photographic equipment for the company Univerzal. ${ }^{77}$ This self-effacing photographer of great talent shot some of the most technically and artistically impressive photographs of the Partisan struggle. The people in his pictures are relaxed and often photographed from a distance, resulting in a propensity for the medium long shot, a format now customary in contemporary photography.

Jovan Ritopečki and Nikola Bibić were some of the Serbian photographers who matured as professionals during their time in the Partisan movement. During the war, Ritopečki worked as a radio technician, war correspondent and photographer for the First Vojvodina Brigade. After the war, he worked for a time as a TANJUG photographer and for the daily newspaper Politika. In 1966 he left for Vienna and became a photographer for the Votava news agency. Four years later he became an independent photographer, working on assignment for the Austrian public broadcaster, ORF, and for other public institutions. His photographs of the lives of so-called Gastarbeiter ('guest workers') in Austria were shot during this time. 


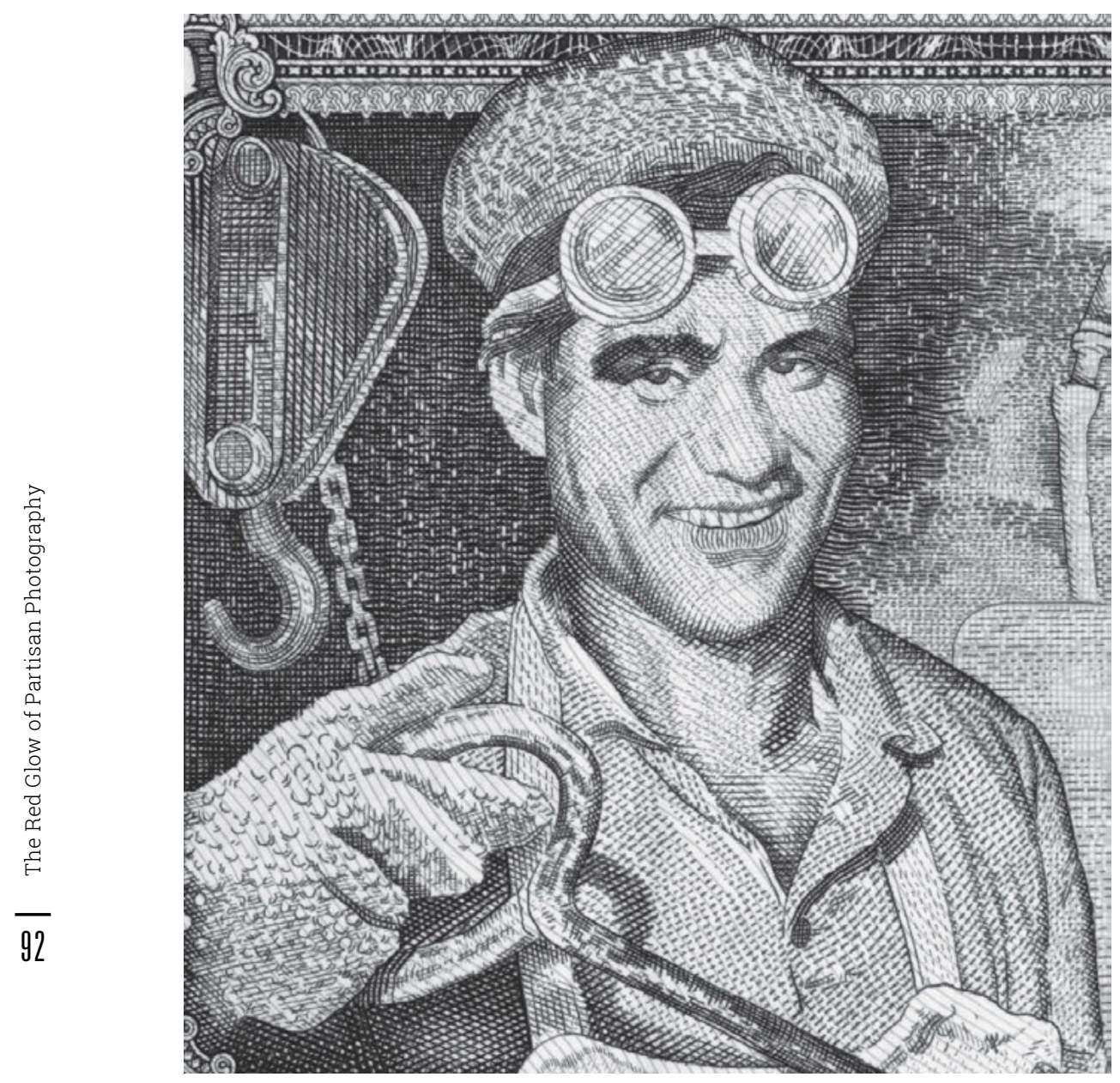

Nikola Bibić's portrait of the Zenica furnace worker Arif Heralić, taken in 1954 and subsequently featured on 1000 dinar notes.

Nikola Bibić learnt his craft from the Serbian photographer Aleksandar Aca Simić, a Belgrade resident not to be confused with Aca Simić from Čačak, who was the official photographer of the Chetnik movement ${ }^{78}$ and a member of the Second Ravna Gora Corps, nowadays widely known as the official photographer of the Chetnik leader Draža Mihailović. During his time in the Partisans, Bibić organised amateur photography courses. His successful photography career continued after the war, and in 1957 he won a World Press Photo prize. He is the photographer behind the portrait of a smiling metal worker (Arif Heralić from Zenica, Bosnia and Herzegovina) whose face was included on 1000-dinar notes in the early 1960s. Vojdrag Berčić filmed a documentary about him in 1967 entitled Devalvacija jednog osmijeha (The Devaluation of a Smile). 
In Bosnia and Herzegovina, the cultural worker, writer and revolutionary Drago Mažar should also be mentioned. This leader of a wartime uprising in Banja Luka was the commander of the Sixth Lika Detachment and he worked as an intelligence officer in the Operational Headquarters of Bosanska Krajina. He lost two brothers in the war - Josip MažarŠoša and Ivica Mažar. All three men were declared official heroes after the war. Drago Mažar shot his first photographs in 1942. Only some of his works have survived. They are now publicly archived at the Archives of the Republic of Srpska but were incompletely accessioned and remain uncatalogued. Some of these photographs were published in the (unpaginated) book Partizanski album, although the images are clearly listed with accompanying technical data. The preface reads as follows:
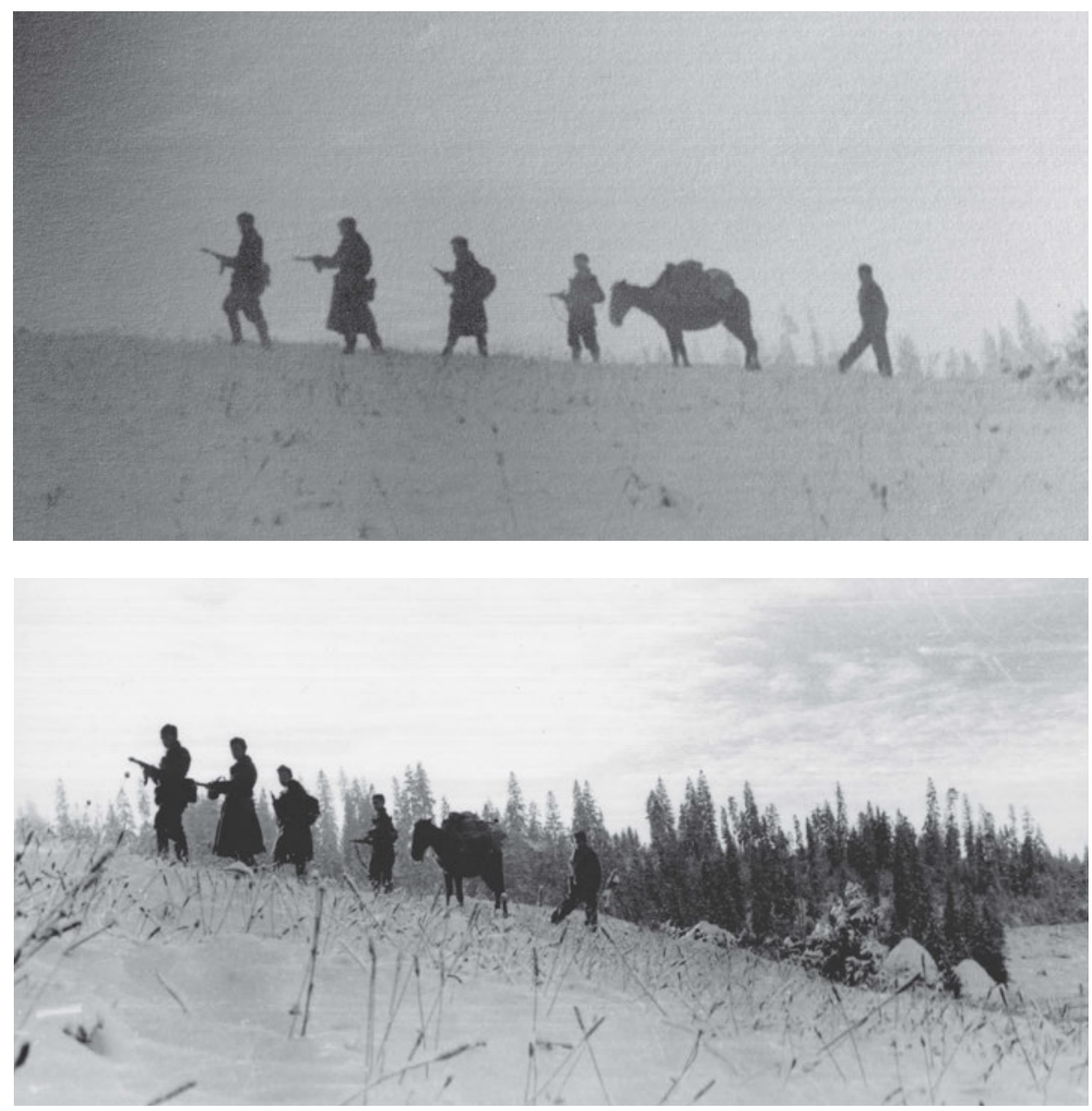

Unidentified scenes shot by photographer Drago Mažar. Archives of the Republic of Srpska, accession no. unknown. 

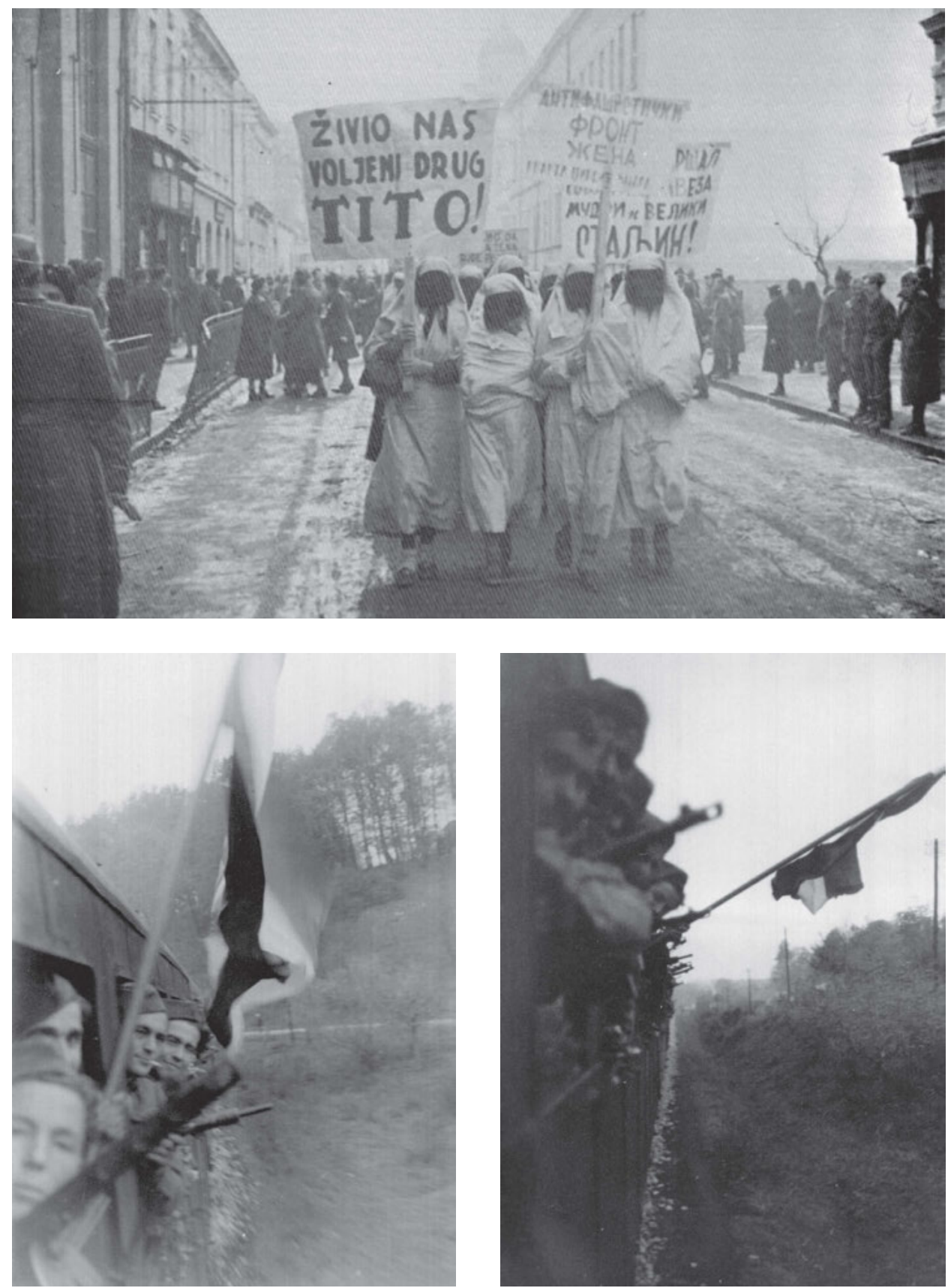

Unidentified scenes shot by photographer Drago Mažar. Archives of the Republic of Srpska. 

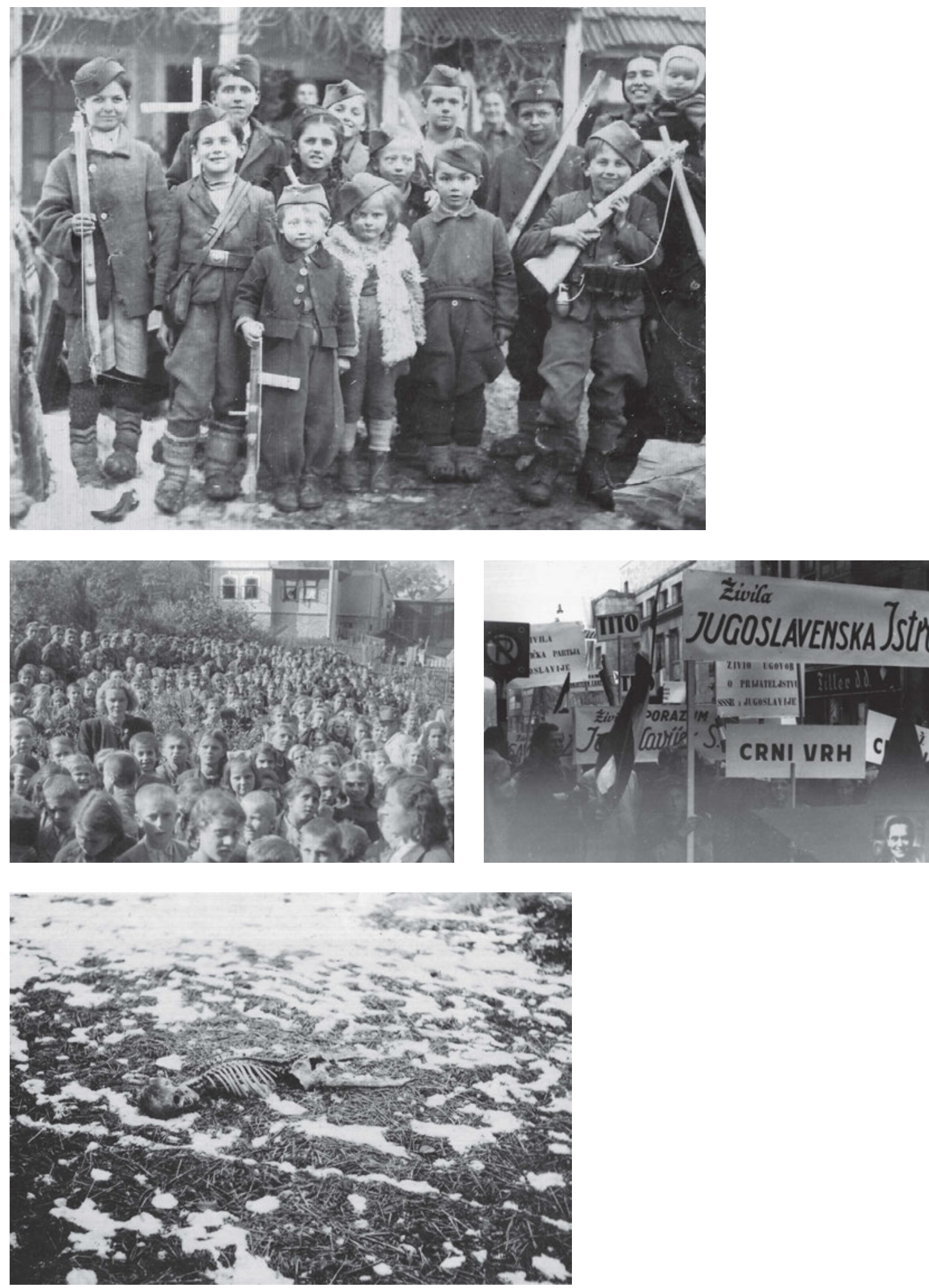

Unidentified scenes shot by photographer Drago Mažar. Archives of the Republic of Srpska. 

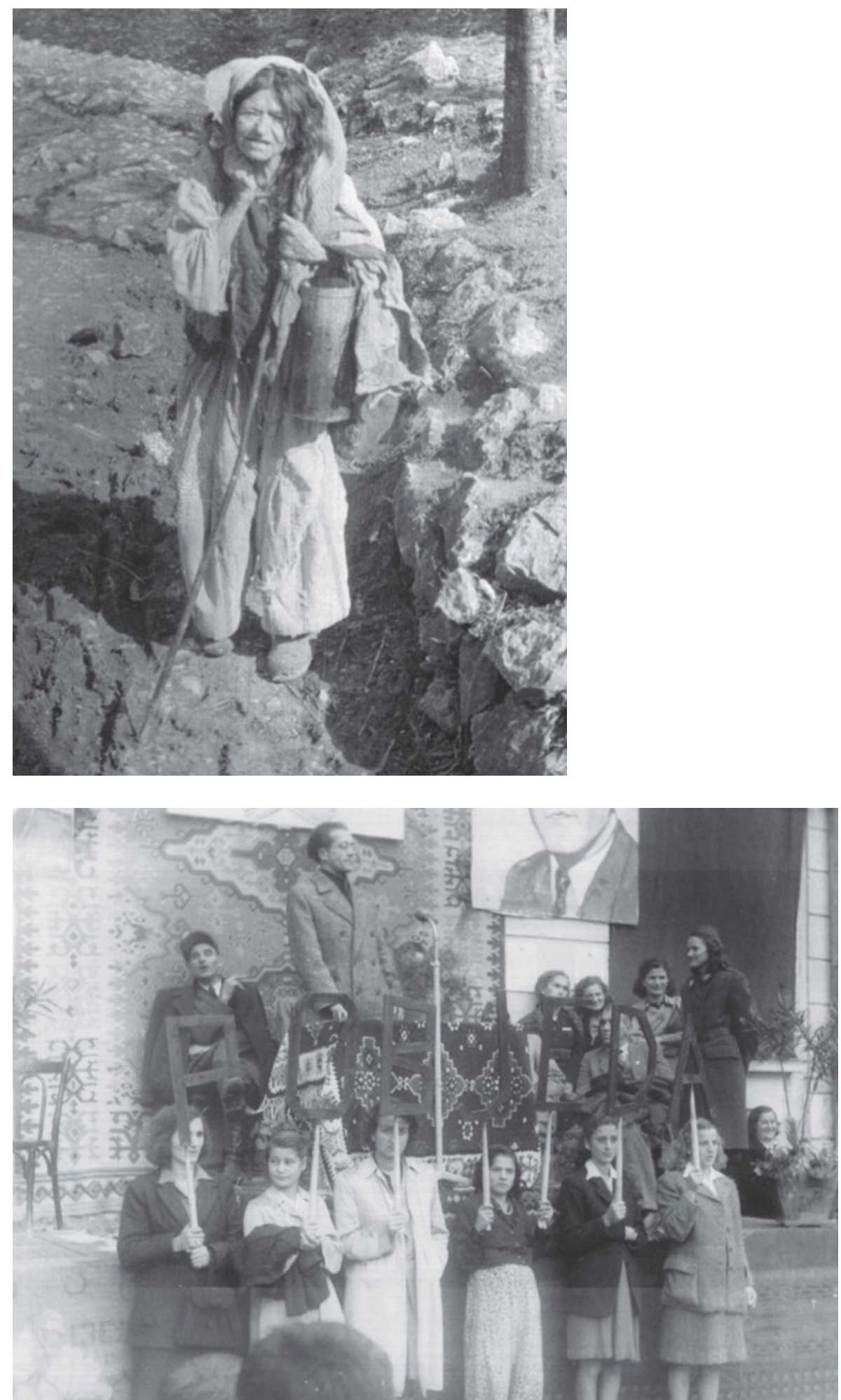

Unidentified scenes shot by photographer Drago Mažar. Archives of the Republic of Srpska. 
Photography doesn't record words, but it does convey the force of situations. These pictures are an important and inspirational confession of a 'photographer'. They are proof of our revolutionary principles and means, relations and opportunities. Yet, together in that powerful witnessing there is also poetry, sometimes with the hardly perceptible tone of an accident only just survived, and more often with the united enthusiasm of an equivalent hope. ${ }^{79}$

The main themes in his photography are freedom and emancipation. Mažar was a socially engaged photographer who captured horrifying scenes of suffering at Kozara in 1942 and the consequences of Operation Western Bosnia. In this operation, German and Ustashe forces, with the support of some Chetnik units, murdered 24,480 civilians, with as many as 8,893 being children under fourteen. According to data supplied by the Ministry of Health Associations and the Red Cross, a further 7,469 children were abducted from 138 villages in the Kozara area. ${ }^{80}$

Throughout the entire war, Savo Orović81 photographed events in the Partisan movement by following units in Montenegro, Bosnia and Herzegovina, Dalmatia, Sandžak, Lika and Kordun. Vladimir Dedijer wrote in the preface to Orović's book Photographs from the National Liberation War (published in English in 1951):

In the first few months of the uprising, Partisan photography units were disorganised; there were just a few amateur photographers working with the scarce resources available. Unfortunately, many of these photographs were destroyed in offensives. How many fighters, how many amateur photographers were lost on the battlefields along with their cameras and films? How many precious pictures were destroyed due to the lack of necessary conditions for developing films? ${ }^{82}$

Skrigin also photographed Josip Broz Tito in Mlinište in September of 1942, while Orović was working on a portrait shoot of the commander. Later, they photographed many famous figures too, such as Koča Popović, Ivan Milutinović, Sava Kovačević, Milovan Đilas, Fjodor Mahin, as well as cultural workers such as Ivan Goran Kovačić, pictured in Livno, where he allegedly just finished writing the poem 'Jama'. As a professional officer, Orović took photographs with military precision. His framing was always extremely precise and his photo enlarging technique meticulous, although his camerawork is somewhat unadventurous in style. One of his most important photographs, depicting Tito injured with a hand on his bandage, and Dr Ivan Ribar, was taken on 9 June 1943 during the battle at Sutjeska, which the poet Kovačić did not survive.

79 Drago Mažar, Partizanski album (with preface by Jovo Popović), Belgrade 1981, unpaginated (4 July).

80 Dragoje Lukić, 'Zločini okupatora i njegovih saradnika nad decom kozarskog područja 1941-1945. godine', in: Kozara u Narodnooslobodilačkoj borbi i socijalističkoj revoluciji: radovi za naučnog skupa održanog na Kozari (Mrakovica) 27. i 28. oktobra 1977. godine, Zdravko Antonić and Joco Marjanović (eds.), Prijedor 1980, p. 283.

81 Savo Orović was a Montenegrin freedom fighter and officer in the army of the Kingdom of Montenegro, a Great War veteran, and later colonel in the Kingdom of Yugoslavia. At the outbreak of the Second World War, he established contact with Partisan units, but in 1942 after the Partisans' defeat in Montenegro, he retreated to Bosnia and Herzegovina. In May 1943 he was awarded the rank of lieutenant general.

82 Savo Orović, Fotografije iz Narodnooslobodilačkog rata 1941-1945, Belgrade 1951, p. 6. 
Orović wrote a letter in December 1943 to Supreme Command, in which he spoke of the scarcity of photographic equipment. Attached to the letter were all photographs taken from December 1941 up to that point, ${ }^{83}$ only 124 in total: 84

Here you are, I am sending you the requested photographs of Partisan campaigns, of Partisan life itself, because the campaigns are mostly carried out at night, and so the most beautiful and pivotal moments of combat cannot be photographed. I am sending almost everything I have photographed and preserved, irrespective of its importance, but neglecting to send one part [that has remained] with the photographer in Bihać and Livno. ${ }^{85}$

His testimony speaks of strict Partisan rules that banned photographing Partisan hospitals, ${ }^{86}$ with further restrictions on the photographing of Allied units, especially on Vis. ${ }^{87}$ In contrast to Orović, the photographer Pavle Bojčević shot a series of photographs from a notably high angle. These shots taken by Bojčević are some of the most powerful photo-

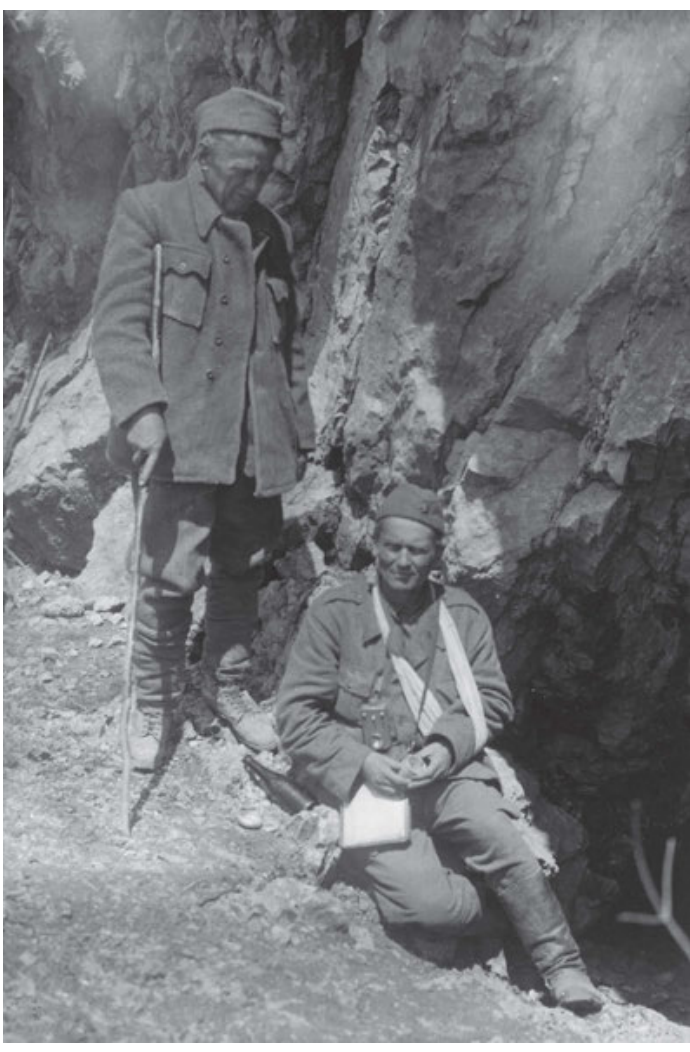

Josip Broz Tito injured at the Milinklada post at Sutjeska, with Dr Ivan Ribar. Photo: Savo Orović. Museum of Yugoslavia.

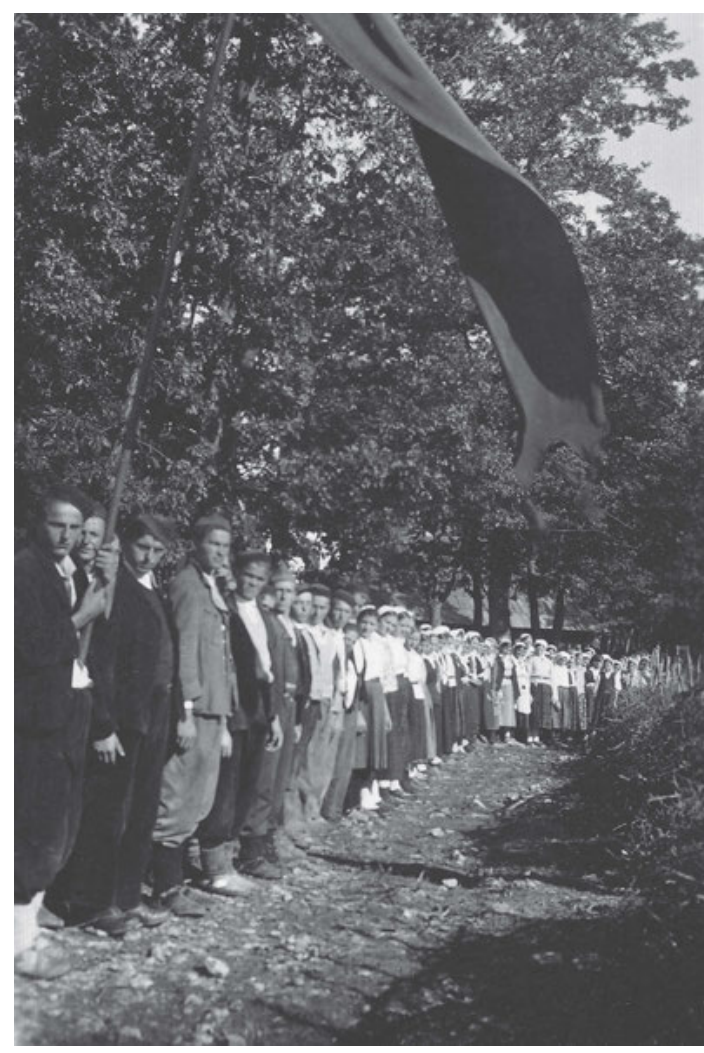

Youth troops at a meeting in Suvaja at Bosanski Petrovac on 25 October 1942 during elections for the District People's Committee. Photo: Savo Orović. Provided with the kind permission of Marko Strpić.

\footnotetext{
83 Ibid., p. 114.

84 Savo Orović, Ratni dnevnik 1941-1945, Belgrade 1972, p. 448.

85 Ibid., p. 448.

86 Ibid., p. 332.

87 Ibid., p. 584.
} 


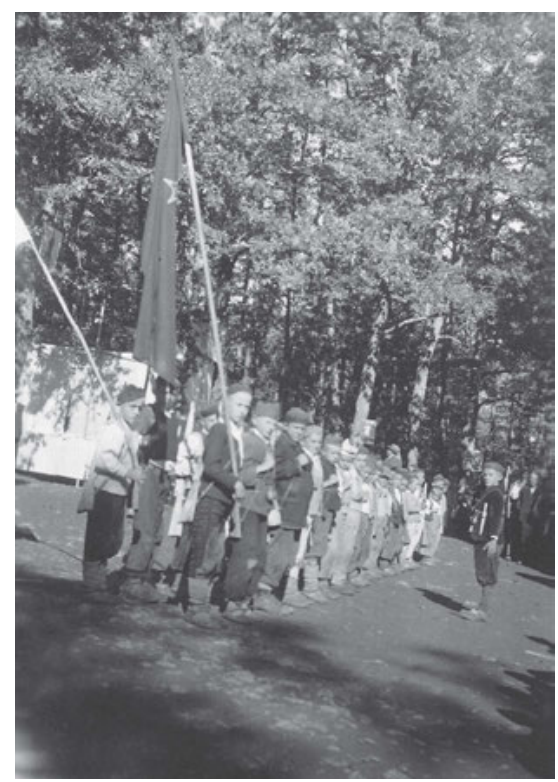

Youth troops at a meeting in Suvaja at Bosanski Petrovac on 25 October 1942 during elections for the District People's Committee. Photo:

Savo Orović. Provided with the kind permission of Marko Strpić.

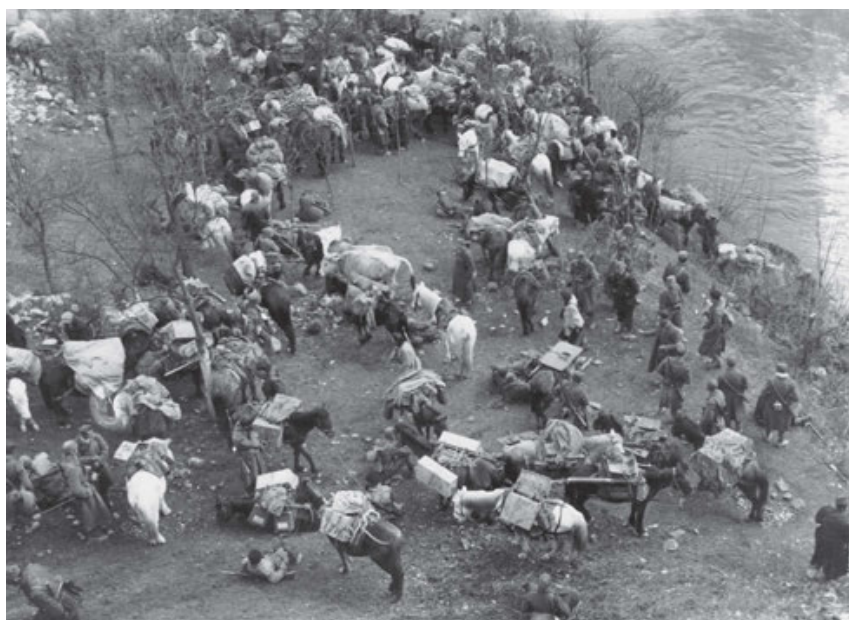

The Battle of Neretva, April 1943. Photo: Pavle Bojčević. Museum of Yugoslavia, MRNJ III - 4557.

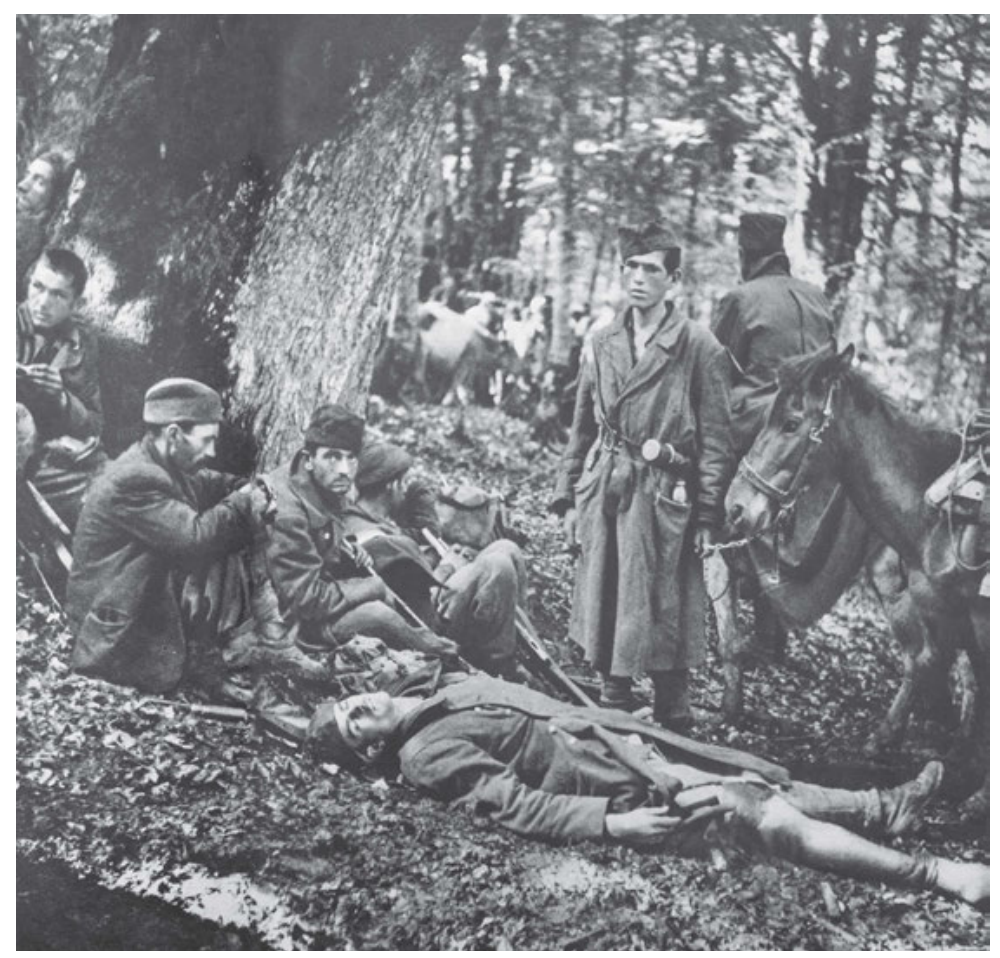

Milinklada at Sutjeska, 9 June 1943. Photo: Žorž Skrigin. Reproduced from the book Rat i pozornica (War and Stage), Belgrade Tourist Press, 1968. 


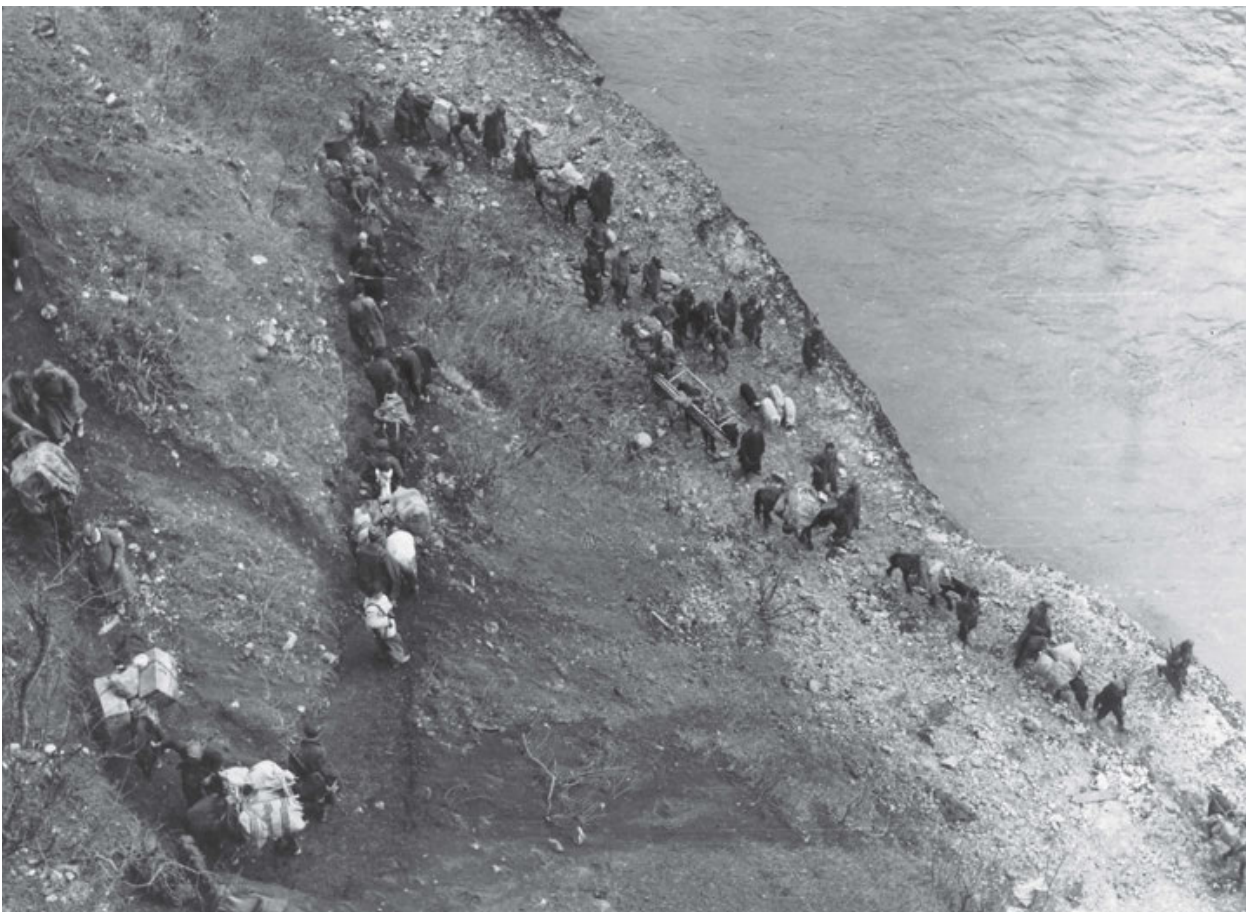

The Fourth Enemy Offensive, April 1943. Photo: Pavle Bojčević. Museum of Yugoslavia, MRNJ III -4557

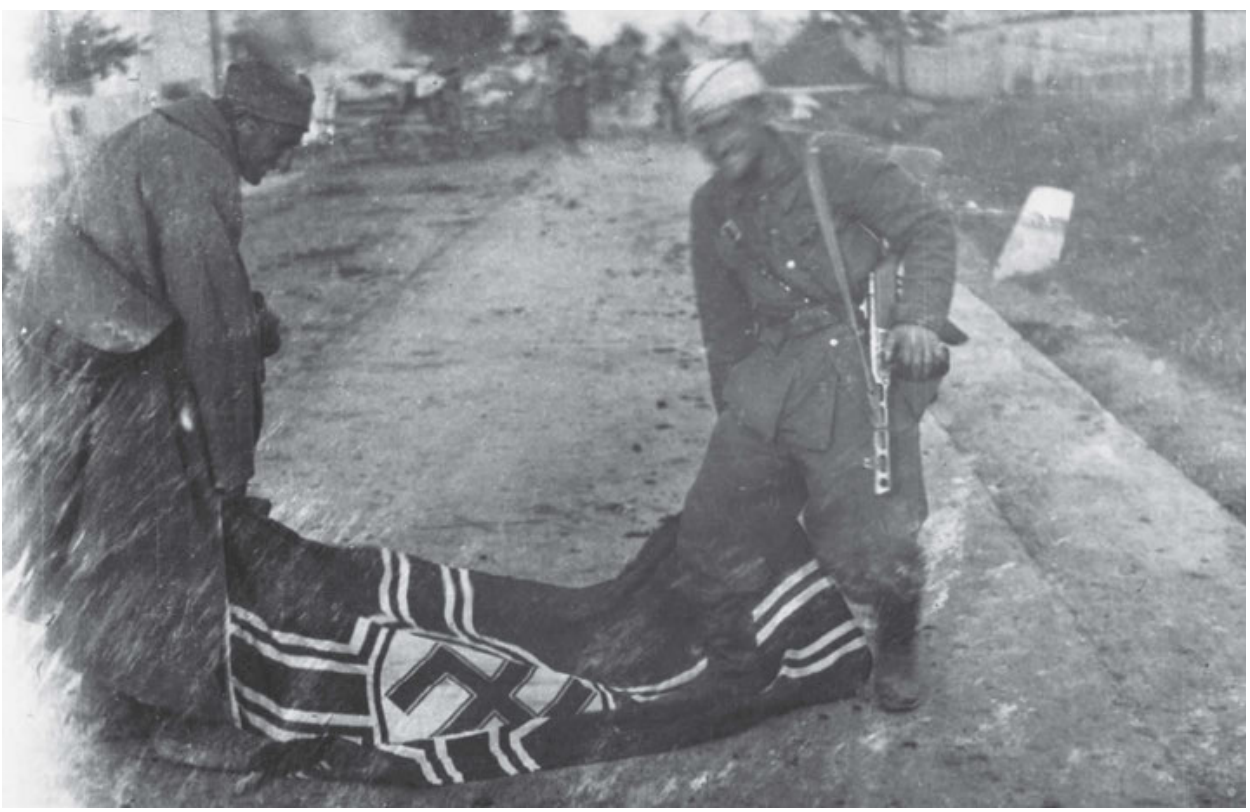

The Corps of the People's Defence of Yugoslavia in Macedonia, 1945. Photographer unknown. Military Museum Belgrade, 13290. 


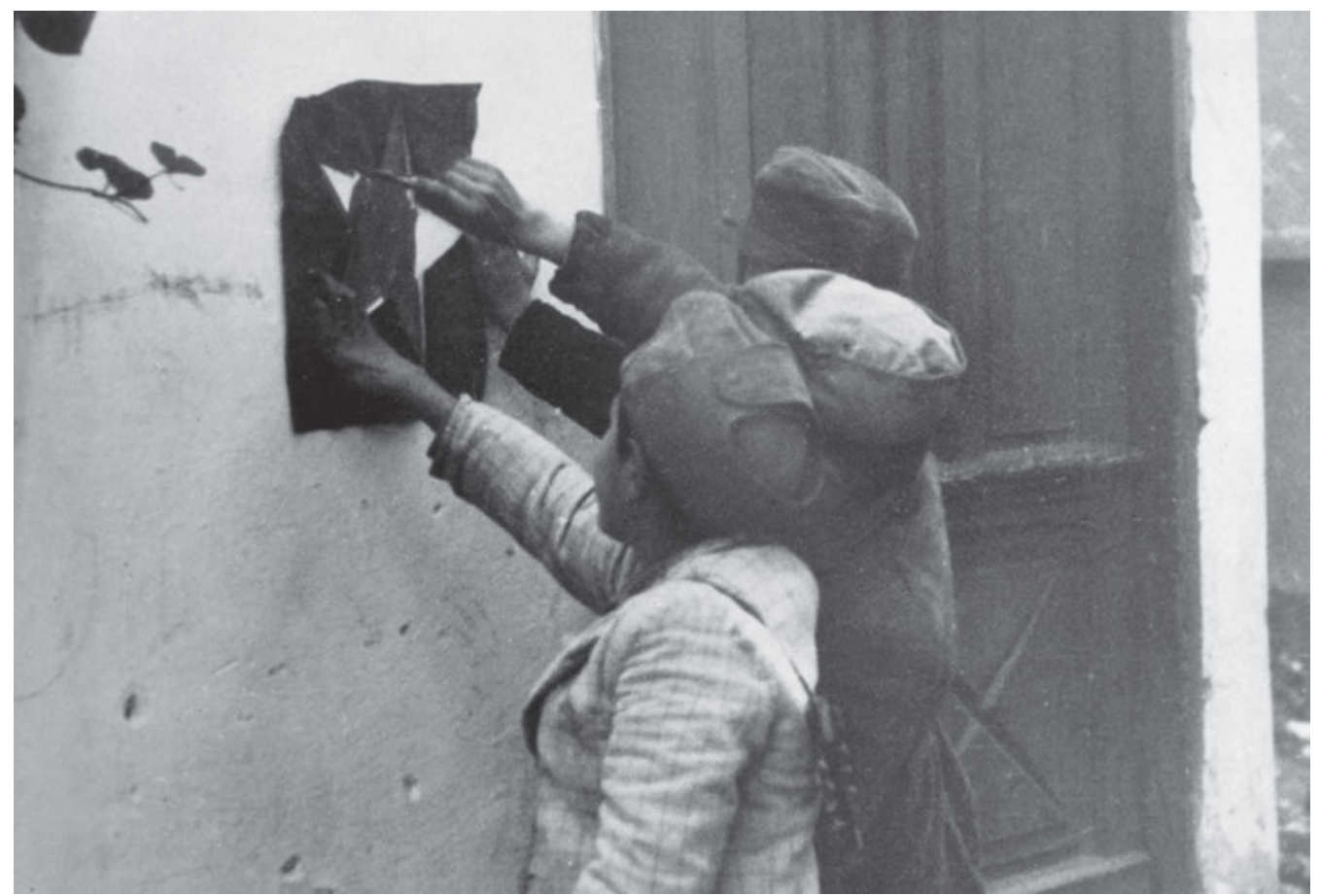

Pioneers paint five-pointed stars on the walls of houses, Skoplje 1945. Photographer unknown. Military Museum Belgrade, 13288.

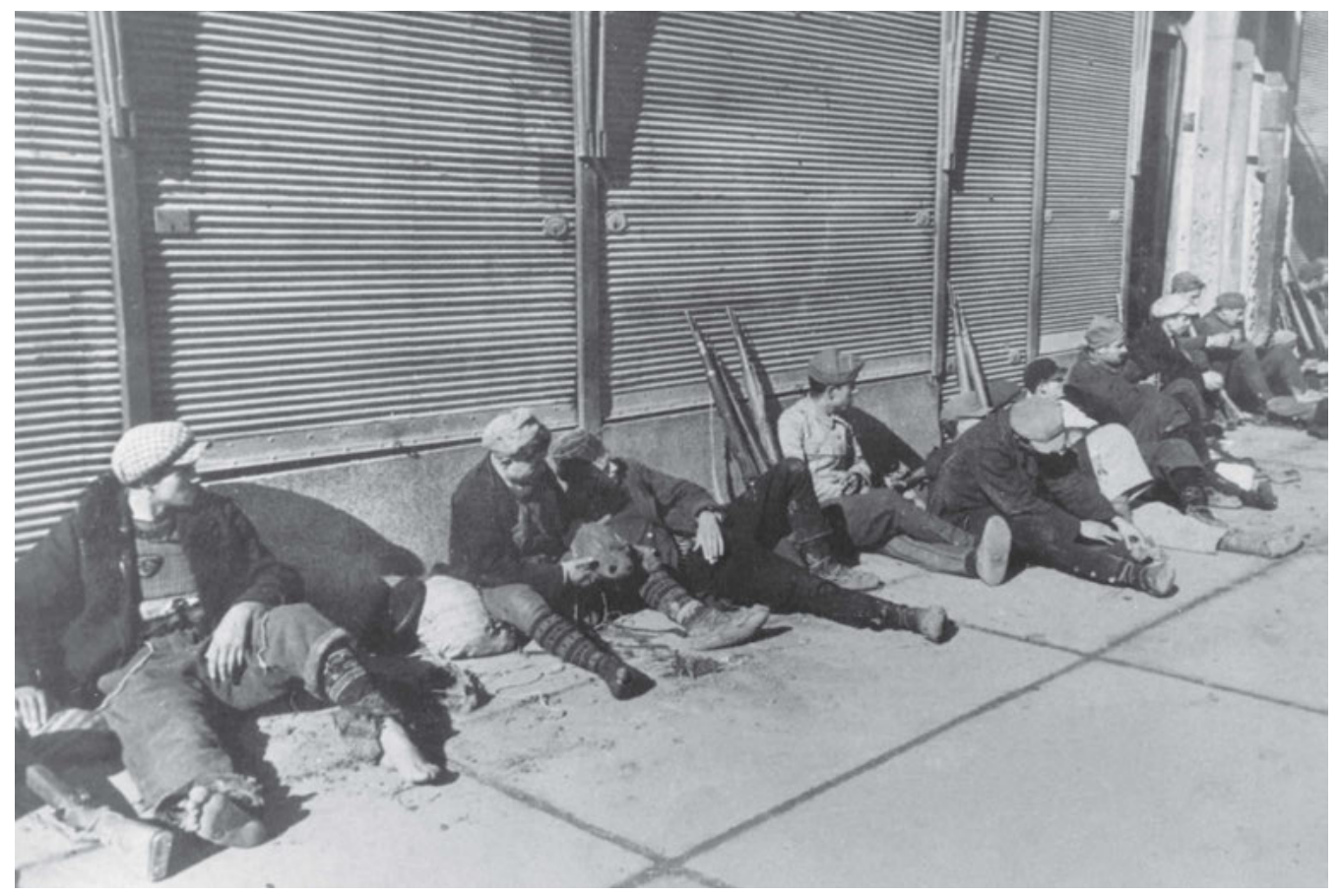

Off-duty soldiers from Macedonian units, November 1944. Skoplje. Photographer unknown. Military Museum Belgrade, 413050. 
graphs of Partisan columns and troop movements. The angle of his shots achieved a monumentality that resulted in filmic scenes that almost appear directed.

In Macedonia, the situation in publishing and cultural production was exceptionally bad. This was ascribed to the division of the state into a Bulgarian and Albanian component, and to the pro-Bulgarian leadership of the regional Communist Party of Yugoslavia, which was late in instigating an armed uprising. Although the Partisan movement itself became a mass movement in 1942, the Central Committee in Macedonia sent Svetozar VukmanovićTempo to organise and strengthen the actions of the Communist Party of Yugoslavia. Yet, in his report to the Central Committee of the Communist Party of Yugoslavia two years later, dated 22 April 1944, he mentions that in Macedonia there were only four newspapers to speak of, with only a handful of journalists and one opera singer from Sofia worth mentioning, but no photographers. ${ }^{88}$ The same information is repeated in all subsequent reports sent during wartime.
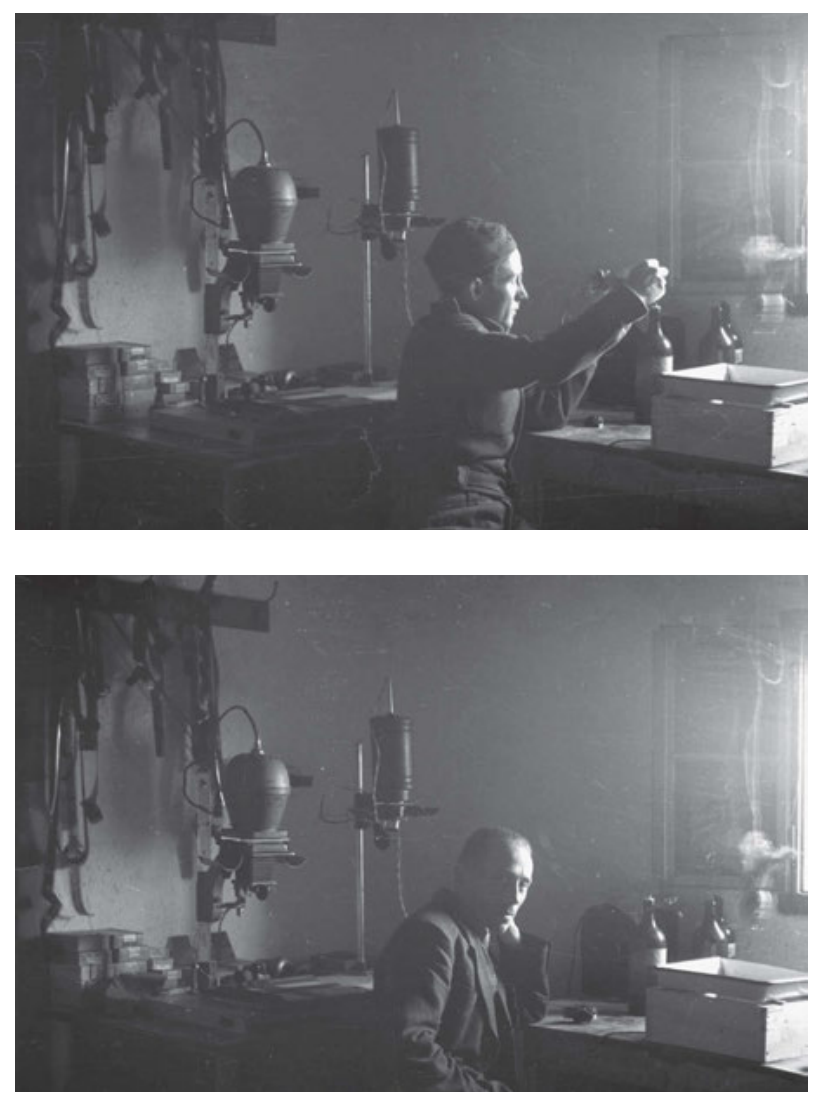

Franjo Veselko, head of the Slovenian war photography unit, at work in the film lab, 23 October 1944. Photo: Maksimilijan Zupančič. National Museum of Contemporary History of Slovenia, TN389/38 


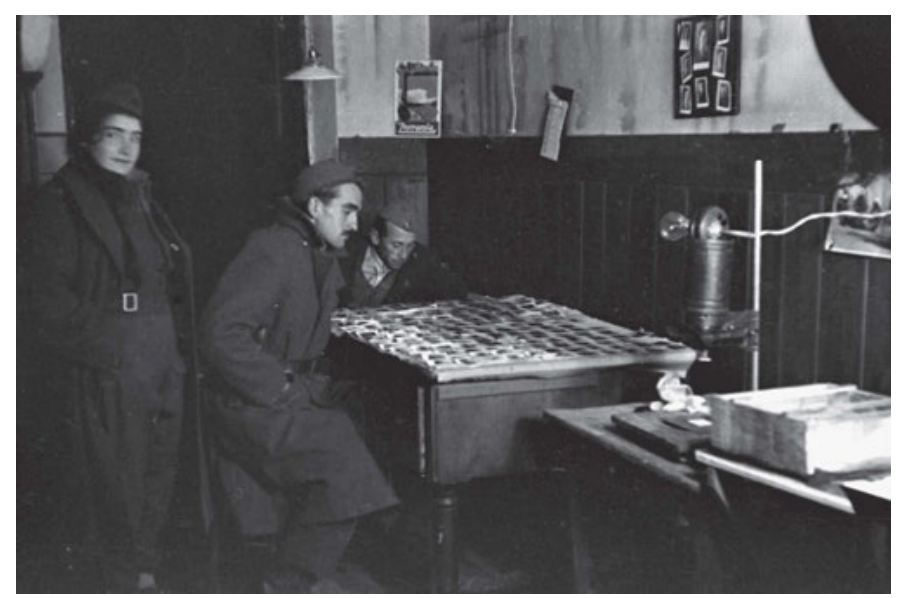

Photography unit of the Slovene People's Liberation Committee of Črnomelj. Photo: Alfred Kos. National Museum of Contemporary History of Slovenia, TN529/4.
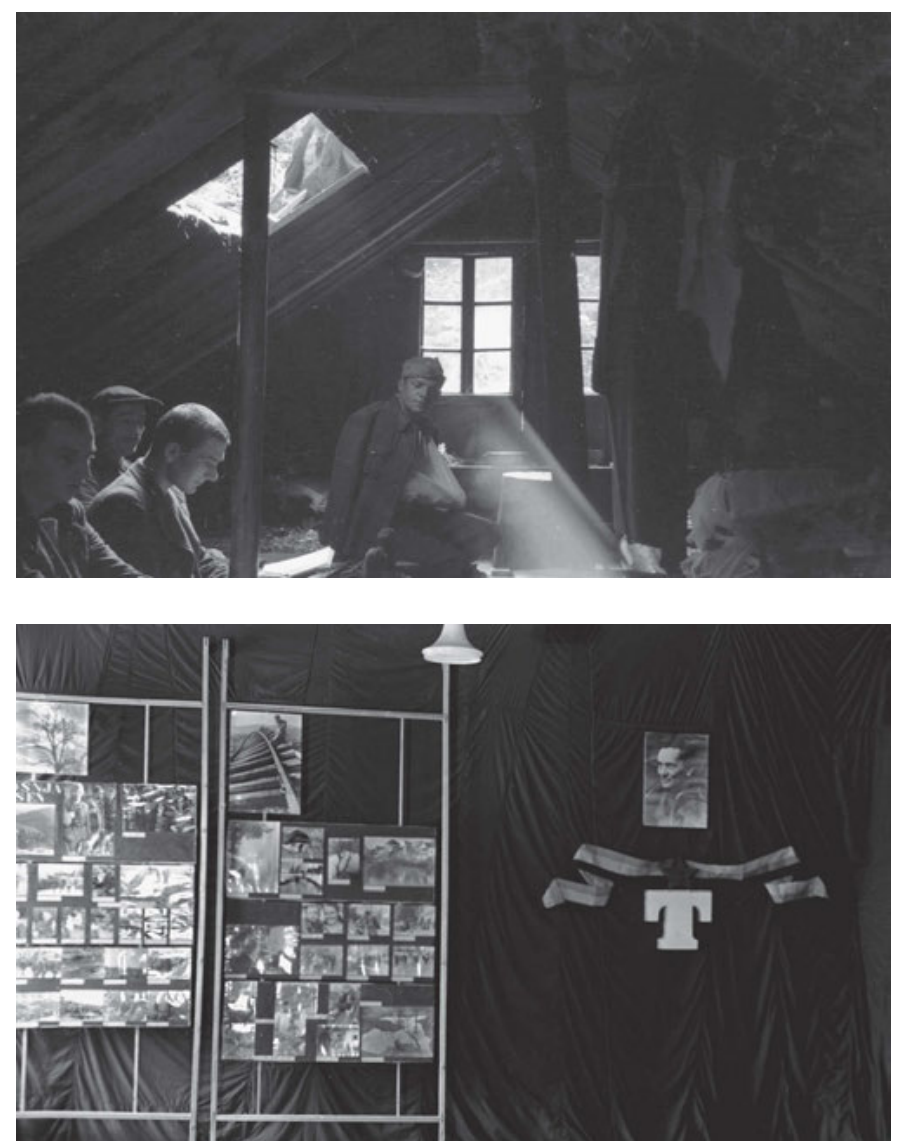

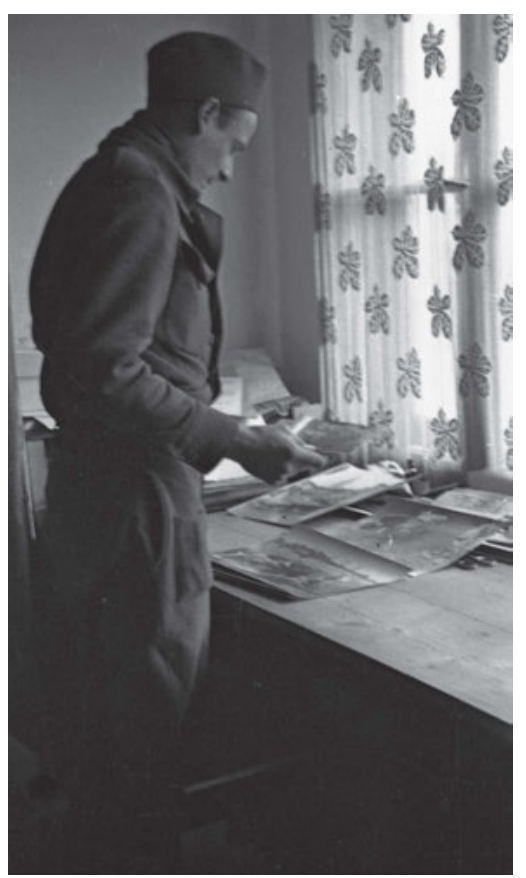

Work in the film lab, Črnomelj.

Photo: Alfred Kos. National Museum of Contemporary History of Slovenia, TN529/22.

Partisan hospital Zgornji Hrastnik, spring 1944. Photo: Dr Janez Milčinski. National Museum of Contemporary History of Slovenia, 1227/15.

Photography exhibition in Črnomelj, 25-31 December 1944.

Photo: Jože Bitenc. National Museum of Contemporary History of Slovenia, TN526/1. 


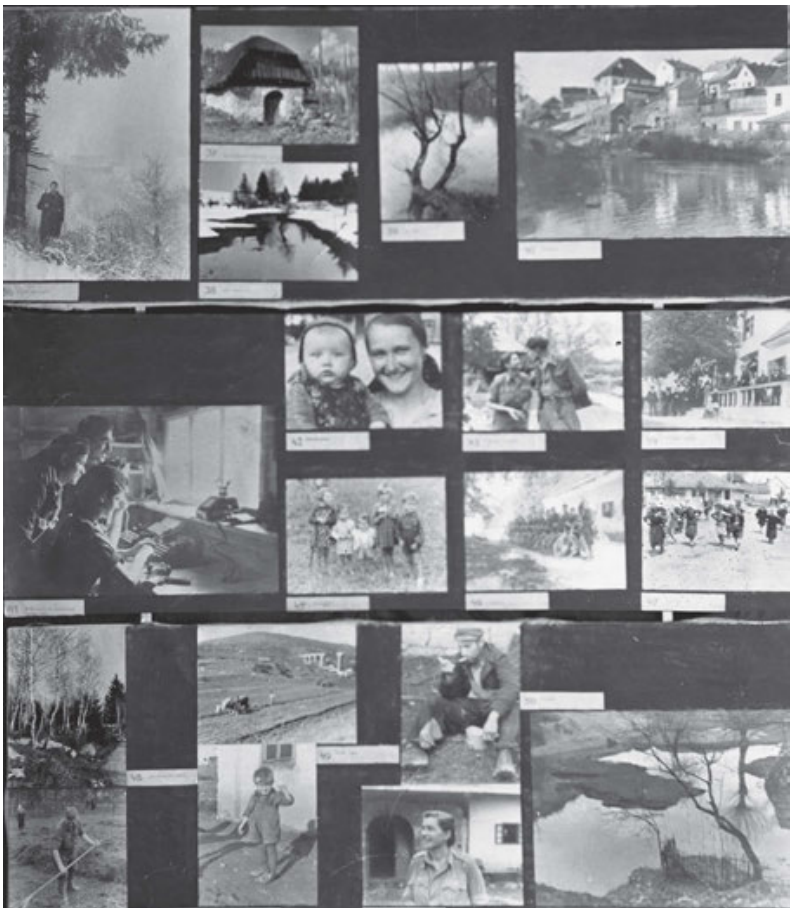

Photography exhibition in Črnomelj, 25-31 December 1944. Photo: Jože Bitenc. National Museum of Contemporary History of Slovenia, TN526/4.

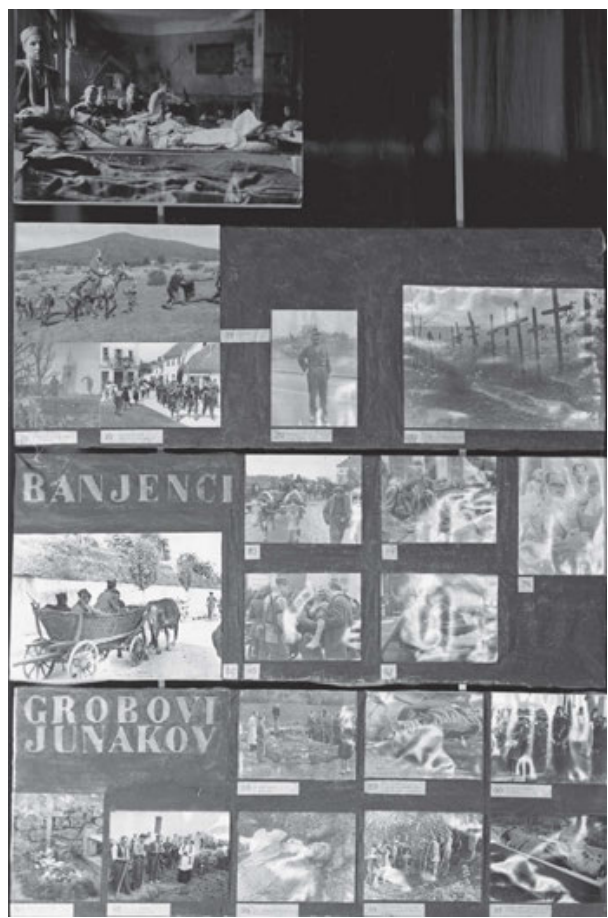

Photography exhibition in Črnomelj, 25-31 December 1944. Photo: Jože Bitenc. National Museum of Contemporary History of Slovenia, TN526/2.

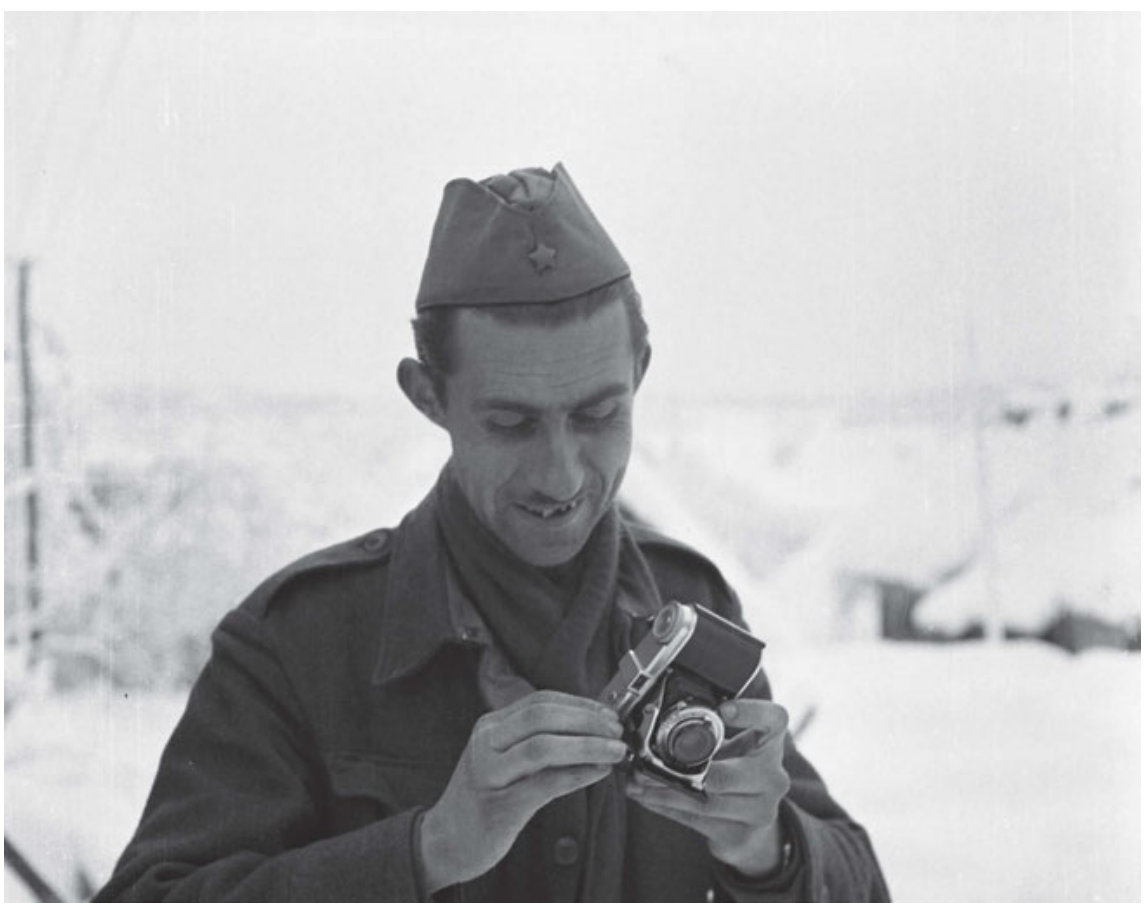

Comrade Stane Viršek at work with a new camera, during a breakthrough of enemy lines by the propaganda department of the People's Liberation Army and the Partisan Detachments of Slovenia, Črnomelj, 28 February 1945. Photographer unknown. National Museum of Contemporary History of Slovenia, TN1628/4. 
After Italy's surrender on 8 September 1943 and the Fifth Enemy Offensive, the Partisans collaborated more closely with the Allies, especially the British. After several years of hesitation, Churchill's government finally recognised the reality on the ground. They recognised the Partisan movement as the only relevant Allied and anti-fascist movement on Yugoslav territory, actively fighting against German and quisling units. The now-open military alliance also resulted in fresh supplies of photographic equipment. The most notable uptick in photographic activities to ensue as a consequence was in Slovenia. This is substantiated by Tomaž Kladnik and Katarina Jurjavčić in their book Vojne fotografije 1941-1945 with the following data:89 In the winter of 1943 and in 1944, the events in Dolenjska were documented by Edi Šelhaus, Mirko Trobec, Miloš Brelih, Vinko Bavec and Gojko Pipenbacher, while events in Gorenjska were documented by Marjan Masterl, in Štajerska by Ivan Lipar-Iztok, in Primorska by Stane Lepardič-Žan and Miroslav Lilik, who were embedded with the Ninth Corps Čoro Škodlar. The Fourteenth Division's campaign, meanwhile, was recorded by Jože Petek. In that period, Alfred Kos, Stane Viršek and Frane Cerar worked as members of the photography unit of the Slovene People's Liberation Committee. The academic painter Božidar Jakac also took photos while in the Partisans, and the history teacher Franjo Veselko photographed the Cankar Brigade..$^{90}$

The Slovenian Partisans boasted one of the best-organised photography units within the Partisan movement. After 1943 the number of photographers grew significantly, compared with the other Yugoslav republics, and exhibition activities intensified. In Cerkno on 23 February 1945, an important photography exhibition went on show marking the twentyseventh anniversary of the Red Army's founding, organised by the propaganda department of the Ninth Corps ${ }^{91}$ Of the works made by Slovenian photographers, that of Jože Petek especially stands out. His observational approach, bravery, and uncompromising documentarism stands in the same league as the works of the eminent war photographer Robert Capa. The interesting works of Dr Janez Milčinski are also worthy of mention, as they present a kind of anthropological analysis of life in Partisan hospitals.

On 5 June 1944, the propaganda department of the General Staff of the People's Liberation Army and the Partisan Detachments of Slovenia showed an exhibition of 118 photographs that opened in Lakner's Salon in Črnomelj, before travelling to Metlika (9 June) and Semič (13 June) - all locations in south-east Slovenia. ${ }^{92}$ The exhibition was split into four thematic blocks: the war crimes of the occupiers, the life and struggle of the Partisan army, caring for the injured and cultural performances. The exhibition attracted around 2,000 people at each venue..$^{93}$ The exhibit finally went on view in Dvor, with around 400 visitors (half of them soldiers). Visitors criticised the lack of photos depicting direct combat, and

\footnotetext{
89 Jurjavčič Dežman, Katarina Jurjavčič and Tomaž Kladnik, Vojne fotografije, 1941-1945: Partizanske enote: iz fotografske zbirke Muzeja novejše Zgodovine Slovenije, Ljubljana 2010.

90 Ibid., p. 22.

91 Mirko Ljubič-Bogo, 'Oris dejavnosti in služb', in: Artilerija 9. Korpusa, Boris Borivoj Lah (ed.), Ljubljana 1985, p. 260.

92 Zbornik dokumenata i podataka o narodno-oslobodilačkom ratu jugoslovenskih naroda, vol. IX/ 6: Partijsko-politička dokumenta 1943. Godine, Belgrade 1967.

93 Ibid.
} 
the lack of a more detailed portrayal of Partisan life. ${ }^{94}$ The Jesenje-Bohinj Detachment in Slovenia, acquired an envious photographic stock, even during wartime, thanks to the efforts of Slavko Smolej, who photographed the final push to victory in Koruška. ${ }^{95}$

The all-encompassing quality of Partisan cultural production and its broad, egalitarian quality led to art becoming open to all - to both the educated and the workers, peasants and artists alike. People who had never written poems became poets, while people who had never told stories became writers. Many photographers evolved into professionals in the wartime period, and many unknown amateurs took their first photographs. As with poets, writers, artists, dancers, sketch artists, musicians, sculptors and painters, photographers too depicted and commented on the world. Their photographs were made not merely to document events or to propagate a 'false' photographic truth. Rather, they were a means of producing their own artistic and political vision of the revolutionary struggle, a struggle that was intended to lead to a lasting peace. In this chapter, we have especially demonstrated that on the ground, under impossible conditions, the Partisans engaged in a lively photographic campaign of picture making, training, dissemination, archiving and exhibiting. The activities were specific to their time and place, determined principally by their role in the nurturing of revolutionary consciousness, yet also by the technical conditions in which Partisan photography evolved. 